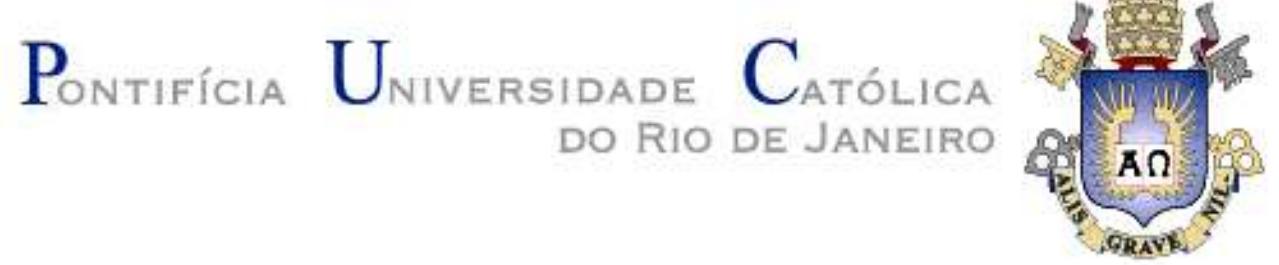

Michelle Pereira de Souza Maia Piñeiro

\title{
A narrativa de comunicação interna da Nissan Motors do Brasil em um contexto de pandemia
}

Dissertação de Mestrado

Dissertação apresentada como requisito parcial para obtenção do grau de Mestre pelo Programa de Pósgraduação em Administração de Empresas do Departamento de Administração da PUC-Rio.

Orientador: Prof. Luís Alexandre Grubits de Paula Pessôa 


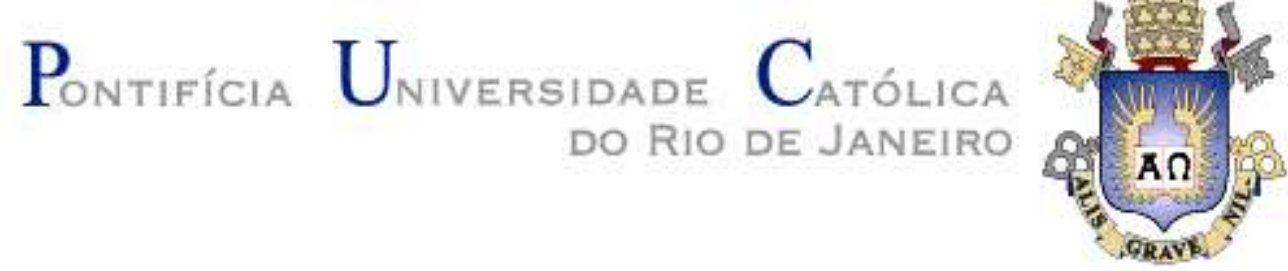

Michelle Pereira de Souza Maia Piñeiro

\title{
A narrativa de comunicação interna da Nissan Motors do Brasil em um contexto de pandemia
}

\begin{abstract}
Dissertação apresentada como requisito parcial para obtenção do grau de Mestre pelo Programa de Pós-Graduação em Administração de Empresas da PUC-Rio. Aprovada pela Comissão Examinadora abaixo.
\end{abstract}

Prof. Luís Alexandre Grubits de Paula Pessôa Orientador Departamento de Administração - PUC-RJ

Profa . Alessandra de Sá Mello da Costa Departamento de Administração - PUC-RJ

Profa. Denise Franca Barros

Universidade do Grande Rio.

Rio de Janeiro, 17 de dezembro de 2020. 
Todos os direitos reservados. A reprodução total ou parcial do trabalho é proibida sem autorização da universidade, da autora e do orientador.

\section{Michelle Pereira de Souza Maia Piñeiro}

Graduou-se em Comunicação Social com ênfase em Publicidade pela PUC-RJ, com MBA executivo em Gestão Estratégica e Econômica de Negócios pela FGV-RJ e extensão internacional em Negociação e administração de Negócios em Harvard.

\section{Ficha Catalográfica}

\section{Piñeiro, Michelle Pereira de Souza Maia}

A narrativa de comunicação interna da Nissan Motors do Brasil em um contexto de pandemia / Michelle Pereira de Souza Maia Piñeiro ; orientador: Luís Alexandre Grubits de Paula Pessôa. - 2020.

102 f. : il. color. ; $30 \mathrm{~cm}$

Dissertação (mestrado)-Pontifícia Universidade Católica do Rio de Janeiro, Departamento de Administração, 2020.

Inclui bibliografia

1. Administração - Teses. 2. Semiótica. 3. Comunicação interna. 4. Marcas automobilísticas. 5. Comunicação organizacional. 6. COVID-19. I. Pessôa, Luís Alexandre Grubits de Paula. II. Pontifícia Universidade Católica do Rio de Janeiro. Departamento de Administração. III. Título.

CDD: 658 
Ao meu marido Arthur Bichmacher, por acreditar em mim e incentivar a minha trajetória.

A minha mãe Rita de Cássia de Souza e avó Iracilda de Souza, por serem meus exemplos de garra e superação. 


\section{Agradecimentos}

Há 3 anos começava a jornada do meu mestrado. Eu acabara de me casar e estava numa fase nova no trabalho, com reuniões infinitas, constantes viagens corporativas e uma promoção de cargo recém assumido. A sensação era que eu tinha o mundo em minhas mãos. E que sensação boa essa, fruto de 10 anos de muito trabalho e dedicação.

No meio da realização pessoal e profissional uma lacuna ainda ecoava em mim: "E agora? Conquistei a minha realização profisssional, sou feliz com a carreira que estou traçando, mas o propósito social? Como retribuir socialmente todo o apoio e suporte acadêmico que eu tive ao longo da minha jornada para ser quem eu sou hoje?" Em meio à tantos pensamentos, um se tornou latente.

A educação é o caminho da transformação. Foi a educação que me transformou, fez uma menina do subúrbio carioca se torna uma mulher, executiva respeitável e ambiciosa no ambiente corporativo. Ambição essa que me faz querer tornar essa mudança, uma nova realidade para muitos jovens.

E "Como?" essa foi a pergunta que me fiz após concluir o "O quê?".

O Mestrado seria o caminho a trilhar, buscando capacitação para esse novo desafio acadêmico.

Nesse percurso, os finais de semana foram deixados de lado, o sonho de fazer o mestrado foi a força impulsionadora para eu voltasse a estudar lógica, equações e inúmeras fórmulas matemáticas que não utilizava desde o meu vestibular.

Nesse momento, eu agradeço o suporte do meu marido Arthur Bichmacher, ele acreditou em mim quando nem eu mesma acreditava. No momento que quase desisti ele me deu forças para continuar e correr atrás dos meus objetivos, me lembrando de fato a minha essência e quem eu era.

Quando se tem um sonho qualquer caminho se torna possível. E eu carrego a certeza de que um dia esse momento, sim exatamente esse momento de escrever meu agradecimento e defender a minha dissertação chegaria.

Após identificar o meu propósito, definir o como eu chegaria lá, veio a pergunta de qual instituição me inscrever. Confesso que essa etapa foi a mais fácil, simples e muito animadora. Eu me tornei "filha da PUC-RJ" em 2007, tive a grande oportunidade de aprender com professores fantásticos e ser orientada para que eu pudesse seguir o meu caminho profissional, com segurança e competência. 
Logo, se havia um lugar que eu deveria fazer o meu mestrado, sem dúvida seria a PUC-RJ, minha casa e berço de formação com muito orgulho. Chegou o dia da AMPAD, senti um frio na barriga que eu não sentia há anos. Nas mãos o terço da minha avó e no coração a fé de que eu conseguiria ser aprovada. Passei e então veio a entrevista, como marco final, eu ouvi do entrevistador: "Seja bem-vinda Michelle, que bom recebe-la de novo na sua casa".

São para momentos como esse que todo esforço vale a pena. Minha mãe disse, "eu tinha certeza que você passaria, você é minha filha, guerreira e obstinada. O mundo é seu, vai ser a melhor aluna".

As aulas começaram, uma turma diversificada e sensacional foi formada, quantos profissionais incríveis e os professores, sem comentários, superaram minhas expectativas em todos os níveis.

Inesquecível, essa é a palavra que melhor define as aulas dos professores Luis Alexandre, professor que eu tive a honra de ter como orientador.

Alessandra Costa, a professora mais empática e com um pensamento fora da caixa que me fez ver o mundo organizacional de outra forma.

Professora Flávia Cavazotte e Marcus Hemais, aulas que aplico hoje no meu dia a dia com muito prazer.

Como maior aprendizado carrego a certeza de que o mundo acadêmico pode, e deve sim ser interligado e aplicado ao mundo corporativo.

Essa será agora minha missão.

Hoje encerro mais um capítulo dessa história, e agora, me sinto preparada para a implementação do meu propósito educacional.

Gratidão a todos que fizeram parte do meu desenvolvimento e que me apoiaram incondicionalmente nessa trajetória.

O presente trabalho foi realizado com apoio da Coordenação de Aperfeiçoamento de Pessoal de Nível Superior - Brasil (CAPES) - Código de Financiamento 001. 


\section{Resumo}

Piñeiro, Michelle Pereira de Souza Maia; Pessôa, Luís Alexandre Grubits de Paula. A narrativa de comunicação interna da Nissan Motors do Brasil em um contexto de pandemia. Rio de Janeiro, 2020. 102p. Dissertação de Mestrado - Departamento de Administração, Pontifícia Universidade Católica do Rio de Janeiro.

A pandemia da COVID-19 mobilizou as organizações que, no esforço para mitigar a contaminação de seus diversos públicos, adaptaram suas rotinas e processos. No que tange às ações voltadas para seus funcionários e prestadores de serviços, a comunicação interna desempenhou papel fundamental. Neste contexto, a presente dissertação tem como objetivo analisar a narrativa de comunicação interna da Nissan Motors do Brasil, implementada durante o período de Pandemia. O corpus da análise é constituído por peças de comunicação interna de e-mail marketing, disponibilizadas pela organização, no recorte temporal de janeiro a agosto de 2020. Do ponto de vista metodológico, fez-se uso de ferramentas de análise semiótica, com ênfase nos temas e figuras empregados no discurso em questão. Os resultados da análise apontam mudanças nas narrativas ao longo do período em questão, com destaque para efeitos de sentido de informalidade e flexibilidade. A pesquisa contribui para a reflexão acerca do processo de comunicação interna da empresa ao cotejar o conteúdo da comunicação com ações e rotinas organizacionais.

\section{Palavras-chave}

Semiótica; Comunicação interna. Marcas automobilísticas; Comunicação organizacional; COVID-19; Nissan Motors do Brasil. 


\section{Abstract}

Piñeiro, Michelle Pereira de Souza Maia; Pessôa, Luís Alexandre Grubits de Paula (Advisor). The internal communication narrative of Nissan Motors of Brazil in a pandemic context. Rio de Janeiro, 2020. 102p. Dissertação de Mestrado - Departamento de Administração, Pontifícia Universidade Católica do Rio de Janeiro.

The COVID-19 pandemic mobilized organizations that, in an effort to mitigate the contamination of their various audiences, adapted their routines and processes. In terms of actions aimed at its employees and service providers, internal communication played a key role. In this context, this dissertation aims to analyze the internal communication narrative of Nissan Motors do Brasil, implemented during the Pandemic period. The corpus of the analysis consists of e-mail marketing pieces, made available by the organization, in the time cut from January to August 2020. From a methodological point of view, we made use of semiotic analysis tools, with emphasis on the themes and figures used in the speech in question. The results of the analysis point to changes in the narratives throughout the period in question, with emphasis on the effects of a sense of informality and flexibility. The research contributes to the reflection about the internal communication process of the company by comparing the communication content with actions and organizational routines.

\section{KeyWords}

Semiotic; Internal communication; Automotive brands; Organizational communication; COVID-19; Nissan Motors of Brazil. 


\section{Sumário}

1 Introdução 13

$\begin{array}{ll}1.1 \text { Problema de Pesquisa } & 18\end{array}$

1.2 Objetivos 20

1.3Relevância Acadêmica e Prática da Pesquisa 20

$\begin{array}{ll}1.4 \text { Organização } & 21\end{array}$

2 Referencial Teórico 22

2.1 Comunicação e Comunicação Interna nas organizações 22

$\begin{array}{ll}2.2 \text { Narrativa e Semiótica } & 25\end{array}$

3 Procedimentos Metodológicos 33

4 A Nissan Motors do Brasil 35

5 Análise 37

5.1 Quebrando a formalidade: período pré-pandemia 38

5.2 Construindo Conexões: período agudo da pandemia 45

5.3 Um novo começo: período de retomada corporativa na pandemia 59

$\begin{array}{ll}5.4 \text { Síntese da análise } & 65\end{array}$

6 Considerações finais $\quad 68$

$\begin{array}{ll}7 \text { Referências Bibliográficas } & 71\end{array}$

8 Anexo I Comunicações internas da pesquisa 75 


\section{Lista de Tabelas}

Tabela 1- Categorias do plano de expansão.............................................. 32

Tabela 2- Distribuição do corpus por período................................................... 34

Tabela 3- Síntese da análise. ..................................................................66 


\section{Lista de Figuras}

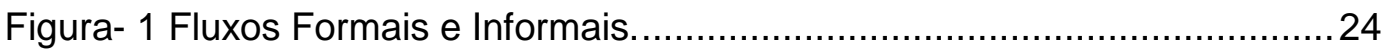

Figura- 2 Esquema do Percurso Gerativo de Sentido. ....................................28

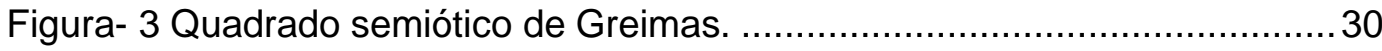

Figura- 4 Comunicação interna publicada em 23 de janeiro de 2020 ................. 39

Figura- 5 Comunicação interna publicada em 10 de fevereiro de 2020 .............. 40

Figura- 6 Comunicação interna publicada em 12 de fevereiro de 2020 .............. 42

Figura- 7 Comunicação interna publicada em 16 de março de 2020 ...................43 43

Figura- 8 Comunicação interna publicada em 17 de março de 2020 ................... 44

Figura- 9 Comunicação interna publicada em 17 de março de 2020.................. 45

Figura- 10 Comunicação interna publicada em 18 de março 2020..................... 47

Figura- 11 Comunicação interna publicada em 18 de março 2020.....................48

Figura- 12 Comunicação interna publicada em 27 de março 2020 ..................... 49

Figura- 13 Comunicação interna publicada em 02 de abril 2020 ....................... 50

Figura- 14 Comunicação interna publicada em 02 de abril 2020.......................51

Figura- 15 Comunicação interna publicada em 09 de abril de $2020 \ldots \ldots \ldots \ldots \ldots . . . . . .52$

Figura- 16 Comunicação interna publicada em 22 de abril de 2020 ...................53

Figura- 17 Comunicação interna publicada em 22 de abril de 2020 ...................54

Figura- 18 Comunicação interna publicada em 30 de abril de 2020 ...................55

Figura- 19 Comunicação interna publicada em 30 de abril de 2020 ...................56

Figura- 20 Comunicação interna publicada em 07 de maio de $2020 \ldots \ldots \ldots \ldots \ldots \ldots . . .57$

Figura- 21 Comunicação interna publicada em 03 de junho de $2020 \ldots \ldots \ldots \ldots . . . . . .58$

Figura- 22 Comunicação interna publicada em 15 de junho de 2020 .................59

Figura- 23 Comunicação interna publicada em 15 de junho de 2020 .................60

Figura- 24 Comunicação interna publicada em 17 de junho de $2020 \ldots \ldots \ldots \ldots \ldots . . . . . .62$

Figura- 25 Comunicação interna publicada em 03 de julho de 2020 ..................63 63

Figura- 26 Comunicação interna publicada em 03 de julho de 2020.................64 


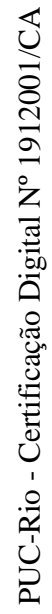

"A persistência é o menor caminho do êxito" Charles Chaplin 


\section{Introdução}

Em dezembro de 2019, um grupo de pacientes com pneumonia de causa desconhecida, mais tarde associada ao Coronavirus, foi vinculado ao Wuhan Seafood Wholesale Market, China.

Os Coronavirus são vírus de RNA envelopados que estão disseminados entre humanos, outros mamíferos e aves e causam doenças respiratórias, intestinais, hepáticas e neurológicas. Seis espécies de Coronavirus são conhecidas por causar doenças em humanos (SU, S. et al., 2016).

O período de incubação varia de 4 a 14 dias, e a taxa de transmissão do vírus é de 2,75, o que significa que uma pessoa infectada transmite em média 2,75 pessoas. Estudos da OMS, mostram que a mortalidade geral da doença é de 3,4\%, aumentando de acordo com a idade da pessoa infectada e com as comorbidades (OMS, 2020).

De acordo com estimativas oficiais, cerca de $80 \%$ das pessoas afetadas por COVID-19 podem ser tratadas em Cuidados de Saúde Primários (APS), pois, apresentam sintomas leves ou são assintomáticos, $14 \%$ necessitarão de hospitalização, com sintomas moderados e 5\% necessitarão de leitos de UTI, por conta de complicações graves (CONASS, 2020, p. 7).

No Brasil, as primeiras ações ligadas à pandemia do COVID-19, começaram em fevereiro de 2020, quando confirmou-se o primeiro caso de Coronavirus do Brasil, em São Paulo. Com a disseminação da doença e novos casos, o Brasil declara Emergência de Saúde Pública de Importância Nacional (ESPIN) e o Congresso Nacional aprova a nova Lei de quarentena (Lei n. ${ }^{\circ} 13$ 979/2020).

Uma das medidas para conter uma pandemia é o isolamento social, que corresponde a isolar o doente de pessoas saudáveis para prevenir a propagação da doença. $\mathrm{O}$ isolamento pode ser vertical, em que apenas os pacientes com risco de doença estão isolados, ou horizontal, em que apenas serviços essenciais são mantidos (CONASS, 2020).

A consequência deste cenário pandêmico é uma situação paradoxal. Afinal, a importância do isolamento social é indiscutível, mas afeta a economia à medida que as pessoas param de produzir e de consumir. 
No momento em que esta dissertação é escrita, a epidemia global do vírus está afetando profundamente o mundo do trabalho. Além de representar uma ameaça à saúde pública, a pandemia tem impacto na economia e na sociedade e, a longo prazo, afetará a subsistência e o bem-estar de milhões de pessoas (CONASS, 2020).

Como consequência desse período turbulento, empresas e pessoas adotam uma postura mais defensiva. Portanto, diante de uma crise, muitas empresas desenvolvem planos de contingência e assim se adaptam à nova realidade com mais agilidade e empatia.

A Organização Internacional do Trabalho (OIT, 2020) estima que, com a pandemia, o surto do vírus levou a um aumento substancial no número de desempregados e subempregados. As estimativas iniciais da OIT (2020), mostram aumento no desemprego global de 5,3 milhões de pessoas em apresentação de um cenário "baixo", o cenário "médio" sugere aumento de 13 milhões de desempregados, e em cenário "alto", este número sobe para 24,7 milhões de pessoas, de uma linha de base de 188 milhões em 2019. (OIT, 2020).

Embora essas estimativas permaneçam incertas, todos os dados apontam para o aumento significativo no desemprego global. Para efeito de comparação, a crise financeira mundial de 2008-2009 fez com que o desemprego aumentasse em 22 milhões de pessoas (OIT, 2020).

As restrições de atividade econômica e à circulação de pessoas afetam a todos os setores de trabalho. De acordo com dados recentes, o valor econômico agregado total do setor manufatureiro na China caiu 13,5\% nos primeiros dois meses de 2020, cadeias de suprimentos globais e regionais foram interrompidas (OIT, 2020).

Vasconcelos (p. 163, 2020) afirma que:

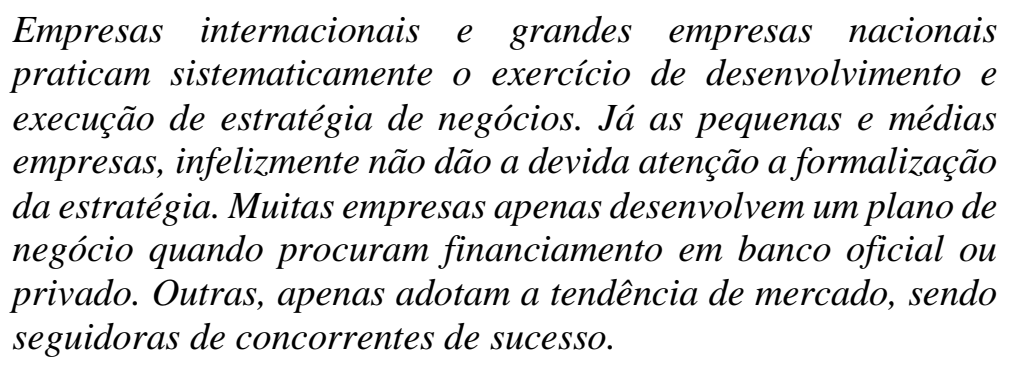

Diante disto, com o advento do Coronavirus, uma pesquisa realizada com empreendedores brasileiros do ramo de serviços e apresentada pela StartSe (2020), aponta que $56 \%$ das empresas estão lutando para sobreviver. Cerca de $32 \%$ dos 
empresários indicaram estarem criando estratégias e procurando formas alternativas de receita, enquanto $12 \%$ dos entrevistados já estavam analisando o novo padrão consumo dos clientes e, portanto, planejando o ponto de saída da crise.

Todavia, os empresários mostraram-se bastante pressionados pelo tempo de recuperação da economia, visto que 39\% deles não conseguem manter a empresa por mais de um mês, $78 \%$ por mais três meses e apenas $10 \%$ relataram ter uma reserva de caixa para sobreviver até doze meses sem novas vendas. A gestão de crises, o equilíbrio dos fluxos financeiros e a retenção de clientes são os principais desafios.

No contexto que diz respeito às relações trabalhistas, o adiamento ou supressão do diálogo com os trabalhadores foi o principal tema das mudanças urgentes nas condições de trabalho.

Duas medidas provisórias foram adotadas para esta questão, a MP n. ${ }^{\circ}$. 927/2020 (BRASIL, 2020) e a MP n. ${ }^{\circ}$ 936/2020 (BRASIL, 2020a).

Essas medidas flexibilizam as regras de trabalho e preveem diversos contratos entre empresas e trabalhadores, a fim de preservar empregos e as empresas sobreviverem à crise. As mudanças incluem aceitação de home office, antecipação de feriados, utilização de banco de horas, suspensão temporária de obrigações, suspensão de contratos de trabalho, bem como redução de jornada de trabalho e salários.

Para Welle et al. (2020), essas medidas são insuficientes para se adequar à situação inicial de renda dos empregos. Ou seja, haveria corte de salários no setor privado porque as medidas não fazem uma recomposição geral da renda de todos os trabalhadores para aqueles que recebem mais de um salário mínimo. Pelos cálculos dos autores, os trabalhadores que recebem os três salários mínimos, dependendo do cenário, terão uma queda de renda de $10,5 \%$ para $42,2 \%$, e os que recebem os cinco salários mínimos, uma perda de $65,3 \%$ da renda inicial.

Uma das principais preocupações levantadas pela pandemia é garantir a segurança dos profissionais. Afinal, uma empresa só pode agir e dar continuidade à entrega se sua equipe estiver segura e em condições de desempenhar suas funções.

Além disso, as organizações tiveram que reforçar a sua responsabilidade social para evitar o alastramento e contaminação da população, consumidores e funcionários, tornando o processo de comunicação interna um aliado primordial. 
Atualmente, a maior parte das organizações opera em mercados competitivos. Com a globalização e difusão das novas tecnologias, a comunicação interna assume papel importante ao nível do fluxo de novas informações, promovendo a discussão e interação entre os diferentes setores da empresa e, principalmente, capacitando os colaboradores para novos desafios (WELLE et al., 2020).

A prática da comunicação é fundamental para garantir que os funcionários estejam alinhados com os objetivos que a empresa está tentando alcançar e para evitar mal-entendidos que podem causar sérios danos ao processo organizacional.

Embora existam muitas maneiras de obter informações e conhecimento, nem sempre significa que estamos nos comunicando. Há uma grande diferença entre comunicação e informação.

Não é diferente em uma empresa. Muita informação é produzida e causa impacto na vida dos funcionários porque não são divulgados de forma adequada e algumas informações nem chegam aos destinatários reais, porque um gerente não identificou a essência comunicativa de um dado fato.

Segundo HOUAISS (2001), a Comunicação Interna é "aquela que se exerce entre a Instituição e o seu público interno e difere também da Comunicação Administrativa, conjunto dos meios e procedimentos utilizados em uma Organização para transmissão de informações, ordens, solicitações, orientações, etc."

Menan (2018), afirma que:

A comunicação interna é uma ferramenta estratégica para a compatibilização dos interesses dos colaboradores e da empresa, através do estímulo do diálogo, à troca de informações e experiências e a participação de todos os níveis hierárquicos da empresa. É, na verdade, um fator contribuinte ao clima organizacional (MENAN, 2018 p. 2).

Para Tavares, em "Comunicação Empresarial e Planos de Comunicação" (2010), comunicação interna é a comunicação entre a empresa e o público interno (colaboradores da empresa).

Tavares (2010, p. 16) acrescenta que a comunicação interna deve ajudar a melhorar a tomada de decisão, buscando eficiência nos processos administrativos, incentivar a proatividade em recursos humanos e trabalhar em conjunto para a descentralização estrutura organizacional, além de promover novos produtos, novos 
serviços, resultados pesquisas, informações sobre os clientes da empresa, etc. por meio de campanhas internas.

Por outro lado, a comunicação interna, com a sua subárea "Comunicação Administrativa", que trata de procedimentos de comunicação mais burocráticos visa, de forma ampla, estabelecer canais e estratégias constitucionais rede eficaz de informação e integração entre os membros da organização.

A comunicação interna durante a pandemia COVID-19 permite uma análise mais aprofundada da teoria e da prática de uma perspectiva interdisciplinar e multicultural. Avaliações conceituais e baseadas em evidências do envolvimento e bem-estar dos funcionários visam melhorar a comunicação entre funcionários de modo que seja efetiva, segura e clara.

Alguns autores defendem a ideia de que a comunicação interna faz parte da Endomarketing ${ }^{1}$. Tavares (2010, p. 17) comenta que esse conceito foi criado por Saul Faingaus Bekin e consiste em "atividades de marketing para a sociedade interna". Autor explica que marketing interno e comunicação interna não são sinônimos que "a comunicação na empresa sempre existirá, independentemente de programa de endomarketing" e o uso deste conceito mais de marketing pode ajudar a tornar a comunicação interna eficaz.

Definir os formatos ou formas a serem trabalhadas e os tempos de ação e, ou inserção de cada técnica é fundamental para liderar a equipe na implementação do plano de comunicação.

O maior desafio de comunicação é o gerenciamento de crises, é imprescindível uma comunicação adequada, sob o risco de suportar danos que podem durar muito tempo. Vale ressaltar que a comunicação desempenha um papel fundamental em tempos de crise, pois é uma ferramenta que conecta as instituições e seus trabalhadores (IQG, 2020). Este tópico do plano deve ser planejado com cuidado pois, sua estratégia é o caminho que a empresa deve seguir para atingir seu objetivo. Lupetti (2007) afirma que:

A estratégia deve liderar o caminho e, como todo mundo forma, isso deve ser feito passo a passo. É definido de acordo com de todas as análises realizadas, as metas estabelecidas, objetivos e

\footnotetext{
${ }^{1}$ Endomarketing, ou marketing interno, são ações de marketing voltadas ao público interno da empresa, fortalecer o relacionamento leal e harmônico entre organização e colaboradores, aumentando o alinhamento, envolvimento e comprometimento dos funcionários com os objetivos estratégicos da empresa. Fonte: https://endomarketing.tv/endomarketing/
} 
posicionamento do produto ou empresa (LUPETTI, 2007, $p$. 107).

O termo estratégia, como explica Lupetti (2007, p. 88), tem origem em uma área militar conhecida como a "arte do guerreiro" no comando exército com habilidades psicológicas e comportamentais. Com o passar dos anos, o termo passou a ser usado em conceitos de gestão. De acordo com a autora "em um ambiente de negócios, a definição de estratégia é bastante diversa sem definição simples e singular “.

Funcionários bem informados sobre o real cenário por que passa a instituição sentem-se mentalmente seguros, o que afeta, entre outros, para a redução de faltas não justificadas, faltas, dispensas.

É importante que as informações sejam atualizadas à medida que novas diretrizes e desenvolvimentos surjam e sejam disseminadas em todos os níveis operacionais. O silêncio pode parecer indiferente aos destinatários internos e externos, portanto, ambos devem ser informados para se certificar de que há o “cuidado" da instituição para com seus colaboradores (IQG, 2020).

Neste contexto, como funcionária da Nissan Motors do Brasil, por 6 anos, na área de planejamento estratégico da América Latina, a autora da dissertação identificou a necessidade de explorar e analisar a comunicação interna da Nissan Brasil, com o intuito de obter melhores práticas de comunicação organizacional de modo que esta seja ampla, clara e objetiva, visando a integralização empresafuncionários.

\subsection{Problema de Pesquisa}

Sendo assim, compreende-se que a informação (e uma construção de sentido pretendida) se revela um instrumento crucial no processo de gestão da comunicação organizacional, ainda mais em momentos de crise como o da pandemia do COVID19. Principalmente em um cenário de globalização em que esses instrumentos são relevantes para ações de fortalecimento da imagem e aproximação organizacional.

Sob esta perspectiva, Bueno (2005) argumenta que:

A comunicação empresarial estratégica precisa estar afinada com a proposta de gestão de conhecimento, que, como ela, está ainda mais difundida do que efetivamente praticada, $e$, definitivamente, resgatar a importância (estratégica!) da 
comunicação interna valorizando a diversidade, o que implica considerar a pluralidade de ideias, vivências e opiniões como atributos fundamentais do moderno processo de gestão. (BUENO, 2005, p. 19).

Em março de 2020, a pandemia atingiu de forma intensa o território brasileiro e ações tiveram que ser implementadas de forma rápida no ambiente organizacional, o que ocasionou esta análise da Nissan Motors do Brasil, uma mudança de narrativa comunicacional.

A decisão corporativa foi priorizar a saúde dos colaboradores e a segurança no controle da COVID-19, por meio de ações organizacionais tais como:

- a flexibilização das rotinas de trabalho, assim, sentimento de empatia foi reforçado para criar um elo eficiente e sólido na relação entre empresa e colaboradores;

- flexibilização dos processos de aprovação e delegação de autoridade para tomada de decisão;

- a implantação ampla do home office, que já era prática comum da Nissan e definido então como "nova" realidade;

- a mudança significativa na esfera da comunicação interna que passou a ter uma nova linguagem e a ser mais visual;

- adoção de novos canais como WhatsApp, site da organização e reforço do e-mail corporativo;

- certificação de que a linguagem aplicada, era adequada aos novos desafios;

- a criação da jornada reduzida "Flex Friday";

- free birthday (liberação do funcionário no dia de aniversário).

Operar logisticamente de forma integral no sistema de home office, ocasionou algumas barreiras de comunicação, mas que a digitalização e o suporte de novas tecnologias auxiliaram e impulsionaram o processo de comunicação interna.

Sendo, assim, foi primordial manter os canais de comunicação atualizados, sobretudo em relação às orientações de controle divulgadas pela OMS e pelo Ministério da Saúde do Brasil (OPAS, 2020).

Durante o período pandêmico novos canais de comunicação foram apresentados como oficiais. Dentre eles o wapps corporativo e lives no Zoom organizadas pelo RH, para promover a integração dos funcionários e proporcionar situações de aproximação e troca de experiências. As peças de comunicação interna 
veiculadas nos canais oficiais da Nissan Brasil, ilustram o plano estratégico que conta com informações claras e suporta com ações táticas um ambiente corporativo equilibrado para mitigar os possíveis riscos que possam afetar a continuidade dos negócios.

Além disso, coube à comunicação interna da Nissan Brasil traçar um plano de acordo com as necessidades de cada uma das áreas da empresa, ambiente administrativo e fabril, para lidar com os impactos no clima organizacional.

É neste contexto que esta pesquisa busca responder às seguintes perguntas:

- Quais foram as mudanças na comunicação para o público interno da empresa Nissan Brasil durante o período inicial de Pandemia?

- Como estas mudanças contribuíram para a implementação de ações organizacionais de flexibilização das rotinas organizacionais?

\subsection{Objetivos}

O objetivo da presente dissertação é (1) analisar as mudanças na comunicação para o público interno da empresa Nissan Brasil durante o início do período de Pandemia; e (2) indicar como contribuíram para a implementação de ações organizacionais de flexibilização das rotinas organizacionais.

Para alcançar o objetivo principal, forma definidos os seguintes objetivos intermediários:

a. Explorar e mapear o material de comunicação interna da Nissan Brasil no período de janeiro a agosto de 2020.

b. Identificar as diferentes estratégias discursivas que marcaram a comunicação da Nissan Brasil no período de janeiro a agosto de 2020, e os pontos de mudança dessas estratégias.

\subsection{Relevância Acadêmica e Prática da Pesquisa}

Este trabalho se justifica por sua relevância para o meio acadêmico, pois possibilita conciliar conceitos e teorias, estudados em diversas disciplinas do curso de Mestrado Profissional em Administração, com a aplicação prática de ferramentas da semiótica francesa, também conhecida como semiótica discursiva ou, ainda, semiótica greimasiana (em referência ao seu fundador A. J. Greimas), para realização do estudo. Com viés de análise de peças de comunicação interna da 
Nissan Brasil, visa identificar estratégias discursivas e mudanças de discurso voltado a situação de Pandemia de COVID-19.

A pesquisa em questão é uma contribuição para reflexão e problematização da narrativa semiótica, mais especificamente no campo da administração, com ênfase em comunicação organizacional, em especial, na comunicação interna, que busca analisar a mudança da estrutura de comunicação para o público interno da empresa Nissan Brasil, implementada durante o período de Pandemia.

Além disso, e fundamental na perspectiva do Mestrado Profissional em Administração, a pesquisa em questão possibilitou à autora para explorar a sua contribuição como funcionária da Nissan Brasil, para a construção de uma narrativa organizacional nas comunicações internas, mais próxima, empática e ajustada ao novo contexto social que se vivencia.

O home office se tornou realidade e com isso, as estruturas rígidas e hierárquicas de comunicação interna terão que ser revistas de forma a definir qual o padrão eficiente para sustentar essa organização.

Provoca-se, portanto, uma discussão sobre as mudanças nas perspectivas de comunicação e suas ênfases de linguagem com a finalidade de colaborar para o entendimento da comunicação interna da Nissan Brasil, gerando insights para melhorar a comunicação com os públicos internos e, outros objetivos de gestão.

Finalmente, a pesquisa também possui relevância prática para além da Nissan Brasil uma vez que contribui para que outras empresas analisem suas práticas de comunicação organizacional a partir da adaptação e mudança de linguagem para a melhoria do entendimento comunicacional com os colaboradores.

\subsection{Organização}

A dissertação está estruturada em seis capítulos. Após a introdução, o capítulo 2 apresenta um referencial teórico sintético da pesquisa. O capítulo 3 detalha os procedimentos metodológicos. No capítulo 4, apresenta-se breve histórico da empresa Nissan Motors do Brasil. No capítulo 5, faz-se as análises de acordo com o recorte de tempo proposto, e a discussão dos resultados obtidos. O capítulo 6 é dedicado as considerações finais da dissertação, percalços da pesquisa, assim como sugestões para análises futuras. 


\section{Referencial Teórico}

\subsection{Comunicação e Comunicação Interna nas organizações}

Para a reflexão desta dissertação, adota-se o termo "comunicação" no sentido de SFez (2000), devido a sua capacidade de incluir a complexidade dos processos de comunicação sob uma perspectiva contemporânea, o que faz sentido no momento em que a pandemia potencializou a complexidade dos processos comunicacionais.

O conceito de comunicação segundo SFez (2000), tem um núcleo epistêmico baseado em duas vertentes, uma que retrata o aspecto tecnológico do termo e outra que é fundamentada nas relações humanas da representação e expressão.

$\mathrm{Na}$ vertente tecnológica, a comunicação é manifestada de forma "objetiva" e "fria" no qual o autor a classifica de "mundo maquinal" - "São máquinas que se fazem, máquinas de traduzir, de falar, de saber, de simular, de produzir a comunicação e de retransmiti-la" (SFEZ, 2000. p.12). Pode-se atribuir essa perspectiva aos canais tradicionais da comunicação interna, como e-mails marketing, por exemplo.

Já no segundo modo, a comunicação é manifestada através da representação e expressão. O termo é apresentado nesse contexto com um sentido metafórico. Nesse modo de expressão a comunicação ocorre através do imaginário em ação, com a intervenção do sujeito, fazendo uso, segundo o autor, de "mecanismos mais complexos, não-lineares, em que o determinado e indeterminado mantém boas relações" (SFEZ, 2000, p.12).

As características descritas por SFez (2000), definem as propriedades das experiências comunicativas de acordo com a forma como elas se apresentam na sociedade contemporânea. Sendo então referência para a análise das transformações pelas quais o conceito de comunicação interna teria passado desde do seu desenvolvimento.

É possível citar aqui rapidamente a circularidade das causas ou a importância do contexto: nenhum elemento do sistema de comunicação está isolado, agindo sobre a situação na rede e sendo objeto da ação dessa situação; ou ainda a reversibilidade ou auto adaptabilidade (sic) de situações em constantes transformações; a informação que circula para transformar os processos internos dos sistemas em presença se produz sobre o 
modelo do contágio, do rumor, não matematizável, e introduzir $o$ aleatório; sem contar a metáfora da simulação, plena de sentido a partir das imagens e do som de síntese, pela qual a realidade e construção da realidade torna-se indissociáveis, em que dentro está fora, e vice-versa, com predominância do paradoxo como procedimento e da interatividade homemmáquina como argumento de venda (SFez, 2000, p.12, grifos do autor).

Novas perspectivas de estudos surgiram na década de 2000, a partir da necessidade de a comunicação ser mais interpretativa como disserta Kunsch (2009) e nesse contexto a comunicação interna emerge como especialidade.

A comunicação organizacional desenvolveu uma identidade interdisciplinar, abrigando várias perspectivas teóricas $e$ pressupostos epistemológicos incluindo (pós) positivismo, realismo, interpretativíssimo, retórica, teoria crítica, pósmodernismo e pós-estruturalismo, feminismo e póscolonialismo. Na primeira década do século XXI, ela pode ser considerada um campo de perspectivas múltiplas e universal em sua abordagem, por seus métodos, suas teorias, seus âmbitos de pesquisa, seus postulados filosóficos. (KUNSCH, 2009, p.71.).

A comunicação organizacional é um dos procedimentos que divulgam a cultura organizacional. É por meio dela que fluxos comunicacionais externos, podem influir nos interesses da organização. Além disso, é por meio da comunicação que os fluxos comunicacionais como, por exemplo, os ativos internos, determinam as estratégias de ação e as tomadas de decisão. Contudo, Kunsch (2009, p.69) ressalta que "o sistema organizacional se viabiliza graças ao sistema de comunicação nele existente, que admitirá sua contínua realimentação e sua sobrevivência".

Para tanto, uma organização não deve oferecer uma imagem que pouco revele sobre o direcionamento de sua conduta organizacional. Porém, deve haver meios que possibilitem que a comunicação, o processo de identificação da empresa, expressando sua cultura organizacional e, ainda, consentindo o processo de constituição do conhecimento.

Mesmo com a tendência do aumento da complexidade, nos estudos da comunicação organizacional, "o modelo mecanicista é o que tem predominado" (Knusch, 2009, p.72):

Esse paradigma considera e avalia a comunicação a partir do prisma funcionalista e da eficácia organizacional, bem como parte da premissa de que o comportamento comunicativo pode 
ser observável e tangível, medido e padronizado. Além disso, preocupa-se com as estruturas formais e informais de comunicação e com as práticas em função dos resultados, deixando de lado as análises dos contextos sociais, políticos, econômicos, tecnológicos e organizacionais. Cremos, que, mesmo em pleno terceiro milênio, as organizações não mudaram muito seu comportamento (Knusch, 2009, p.72).

Dada a existência de fluxos informacionais (Figura 1), formais ou informais, a informação transcorre todos os ambientes da empresa, fazendo parte dos processos organizacionais de forma natural, conseguindo existir sob a forma registrada e não registrada (VALENTIM 2003).

Figura- 1 Fluxos Formais e Informais.

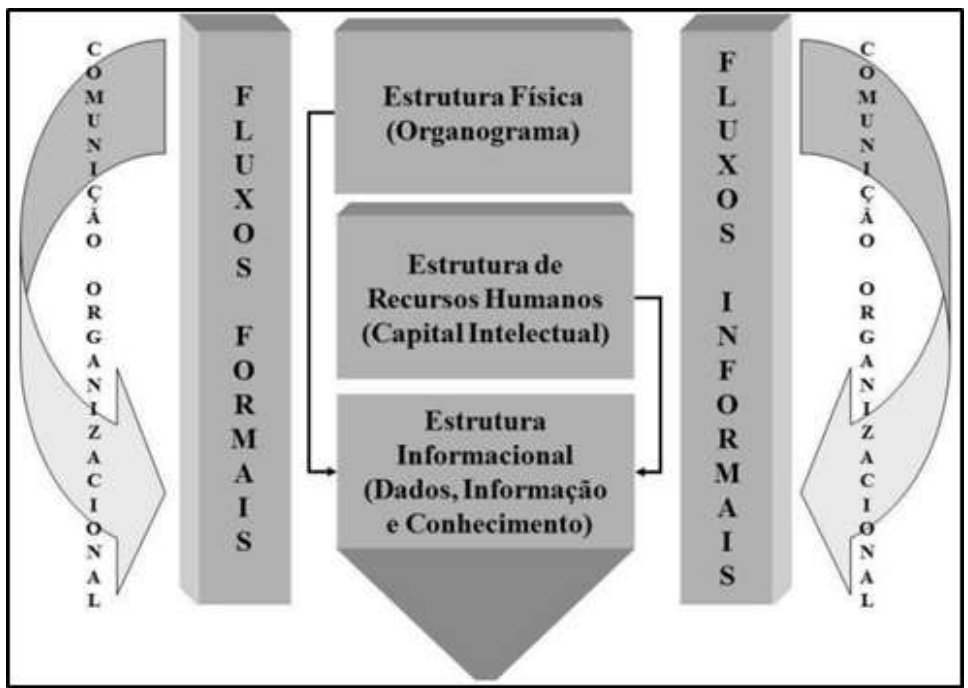

Fonte: Valentim, (2002).

Decorrentes da própria estrutura da empresa, os fluxos formais são rotinas e elementos aplicados aos fazeres produtivos, pertinentes ao organograma da empresa.

Nesse caso, a informação registrada decorre dos sistemas formais da empresa, tais como, portais corporativos, redes Intranet, relatórios, registros, documentos contendo normas e códigos, entre outros.

E sob a configuração não registrada, a informação circula, por exemplo, por meio de reuniões, cursos e eventos formalizados, mas que não foram especificados em determinado suporte.

Quanto aos fluxos informais, esses surgem espontaneamente, através da relação interpessoal interna ou externa à organização, e estão diretamente relacionados à estrutura cognitiva dos indivíduos que atuam na organização. 
Ressalta-se que os fluxos informais não são registrados em algum suporte, considerando se tratarem de diálogos e interações não formalizados entre os sujeitos organizacionais. Os fluxos informacionais são o elo entre uma fonte e um receptor, que resulta na transferência de informações de maneira formalizada ou não (VALENTIN, 2002).

Sobre os fluxos formais e informais de informação existentes em todas as áreas de uma organização, Valentim (2002), argumenta ser possível mapear esses fluxos informais, assim como é possível identificar e mapear os fluxos formais de informação, a partir do reconhecimento de três ambientes:

[...] o primeiro está ligado ao próprio organograma, isto é, às inter-relações entre as diferentes unidades de trabalho como diretorias, gerências, divisões, departamentos, setores, seções etc.; o segundo está relacionado à estrutura de recursos humanos, isto é, as relações entre pessoas das diferentes unidades de trabalho e, o terceiro e último, é composto pela estrutura informacional, ou seja, geração de dados, informação e conhecimento pelos dois ambientes anteriores (VALENTIM, 2002, p.3).

Nesse sentido, Bueno (2005, p.12) aponta ser mandatório ponderar que a comunicação empresarial requer a noção de que esta ocorre de modo holístico, pois “não se realiza à margem das organizações, mas está umbilicalmente associada a um particular sistema de gestão, a uma específica cultura organizacional e que é expressão, portanto, de uma realidade concreta".

Ainda segundo o autor, a comunicação organizacional deve refletir o estilo de gestão e não ser tratada apenas como um instrumento. Naturalmente, um dos recursos principais para que a comunicação empresarial seja tomada como estratégica, habita na própria gestão da informação como meio para a constituição do conhecimento.

\subsection{Narrativa e Semiótica}

Desde a década de 1990, a narrativa tem sido usada como ferramenta analítica e metodológica e com foco na construção de conhecimento sobre a transformação organizacional (ALVESSON e KARREMAN, 2000).

Embora arquétipos sejam manifestos desde os anos 1950, o uso de narrativa na pesquisa organizacional, as viradas pós-modernas e linguísticas, nos estudos organizacionais acresceram a popularidade da linguagem e ferramentas abalizadas 
em texto para analisar narrativas, histórias, discursos e conversas (ALVESSON e KARREMAN, 2000).

No argumento peculiar dos estudos organizacionais, a narrativa oferece aos estudiosos ensejos de explorar não somente as experiências humanas, mas também as várias formas de fala e texto que ocorrem. Dessa forma, a Semiótica, em suas diversas correntes teóricas, se apresenta como uma possibilidade teóricometodológica para o campo.

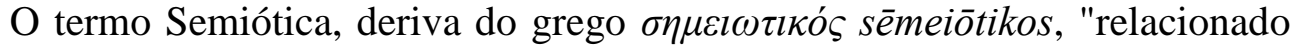

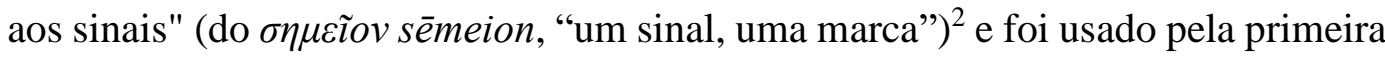
vez pelo inglês Henry Stubbes em 1676, para classificar como o ramo da ciência médica relacionado à interpretação dos signos.

Ao aplicar o conceito da semiótica, é necessário definir com qual teoria pretende-se trabalhar. Há três correntes teóricas, elencadas a seguir de forma cronológica (SILVA, 2011):

- $\quad$ semiótica de origem americana, desenvolvida por Charles Sanders Peirce (1839-1914);

- $\quad$ semiótica de origem francesa, criada por Algirdas Julien Greimas (19171992);

- semiótica da cultura, construída a partir de um grupo reconhecido como Escola de Tartu-Moscou, cujo nome principal é Iuri Lótman (1922-1993).

A semiótica faz parte das ciências da linguagem e corresponde a conjuntos significativos, o sujeito de sua análise é o signo, entendido em sentido amplo (verbal, não verbal, texto sincrético), ou seja, tudo o que gera sentido para o que é analisado.

Quando aplicado, propõe um estudo do conteúdo, destacando assim a arquitetura, ou seja, a forma como o texto se constitui estruturalmente para expressar a mensagem. Dessa forma, o caminho generativo serve para explicar a construção semântica do significado: como o significado é construído no texto, por meio da linguagem e dos símbolos identificados.

[...] essa estratificação considera simplesmente a significação por meio de um folheado, como a massa do mesmo nome ou as camadas geológicas, ainda que essas metáforas sejam

\footnotetext{
2 "The branch of medical science relating to the interpretation of symptoms", Oxford English Dictionary (1989).
} 
enganosas: não se trata de uma simples superposição cumulativa, mas antes, como se tentou mostrar, de uma rede hierarquizada de dependências em que cada um dos níveis mais profundos converte seus dados semânticos e sintáticos, articulando-os e especificando-os no momento de sua passagem ao grau superior (BERTRAND, 2003, p. 47).

Compreende-se então que a semiótica é o estudo da construção de significado, através do significado geral da comunicação e da análise do processo de signo (semiose). A tradição semiótica explora o estudo de signos e símbolos como parte significativa das comunicações (BERTRAND, 2003).

E se diferencia assim da linguística. Ou seja, a semiótica é a disciplina que estuda o fenômeno de significado e comunicação. Logo, compreende-se significado como relação que liga qualquer coisa "materialmente presente", tácita a qualquer coisa de "ausente", como uma luz vermelha em um semáforo passa a mensagem de "pare".

É importante destacar a ligação entre significado e comunicação, pois cada vez que se põe em prática uma relação de significado, inicia-se um processo de comunicação (BERTRAND, 2003).

Porém, uma renovação na teoria semiótica adveio com a inclusão nos anos 1970 dos estudos da enunciação, que cooperou para a mudança de um modelo meramente imanentista a uma abordagem extralinguística dos objetos analisados.

Com uma perspectiva estrutural para apresentar o sistema da língua, a semiótica favorecia o enunciado e abdicava da subjetividade. Apresentava-se qualquer conjunto significante, independentemente da forma ou da linguagem, com supressão de qualquer elemento extralinguístico. O legado estrutural era patente (SILVA, 2011).

Preponderava, portanto, o princípio da objetivação, da imanência. Sendo assim, a enunciação permanece nesse primeiro estágio em segundo plano, abandonando o sujeito do discurso de sua reflexão (CORTINA; MARCHEZAN, 2004. p. 410-14).

A absorção da teoria da enunciação pela semiótica francesa a possibilita avançar para além da herança estruturalista (PESSÔA, 2013) e a torna mais adequada aos estudos de comunicação, de uma forma geral.

Esta dissertação tem como fundamento teórico a semiótica francesa, da Escola de Paris, criada com o propósito de ser uma teoria da significação. Visto que 
a teoria de Greimas aponta a interpretação dos elementos significativos de um texto, a semiótica é a ciência da linguagem que analisa a relação dos signos entre si e agrupados, e a sua disposição de construção de sentido:

A semiótica deveria ocupar, em relação às ciências humanas, o lugar que a língua, segundo Hjelmslev, ocupa frente aos demais sistemas semióticos, e que decorre de sua capacidade de assegurar a traduzibilidade entre outros sistemas. (FONTANILLE \& ZILBERBERG, 2001, p. 55).

Greimas assegura que a semiótica tem como objeto de estudo os sistemas semióticos e não o signo. Seguindo os princípios básicos da linguística de Saussure, quanto a significação e significante, e de Louis Hjelmslev, no que diz respeito aos conceitos de plano de conteúdo e de expressão, Greimas considera como objeto de significação e de comunicação, o texto e para fazer uma análise semiótica é necessário percebermos o percurso gerativo de sentido de um texto (MODRO, 2007).

Para erigir o sentido, então, a semiótica de linha francesa idealiza o seu plano de conteúdo sob a configuração de um percurso gerativo de sentido (Figura 2), dividido em etapas que têm uma sintaxe e uma semântica próprias.

$\mathrm{O}$ esquema de percurso configura-se da seguinte forma:

Figura- 2 Esquema do Percurso Gerativo de Sentido.

\begin{tabular}{|c|c|c|c|}
\hline \multirow{4}{*}{ Estruturas sêmio- narrativas } & \multicolumn{2}{|c|}{ Componente Sintático } & \multirow{4}{*}{$\begin{array}{l}\text { Componente Semântico } \\
\text { Semântica fundamental } \\
\text { Semântica narrativa }\end{array}$} \\
\hline & \multirow{2}{*}{\multicolumn{2}{|c|}{\begin{tabular}{l|l} 
Nivel & Sintaxe \\
profundo & fundamental
\end{tabular}}} & \\
\hline & & & \\
\hline & $\begin{array}{l}\text { Nivel de } \\
\text { superficie }\end{array}$ & $\begin{array}{l}\text { Sintaxe } \\
\text { narrativa }\end{array}$ & \\
\hline Estruturas discursivas & \multicolumn{2}{|c|}{$\begin{array}{l}\text { Sintaxe discursiva } \\
\text { Discursivização(actorializa- } \\
\text { ção, temporalização, espacia- } \\
\text { lização) }\end{array}$} & $\begin{array}{l}\text { Semântica discursiva } \\
\text { Tematização } \\
\text { figurativização }\end{array}$ \\
\hline
\end{tabular}

Fonte: BORBA, (2005).

O quadrado semiótico (o componente sintático do nível profundo), ou modelo teórico da estrutura elementar da significação, é elemento central no paradigma semiótico greimasiano e em grande parte responsável pela fecundidade e alcance da teoria de Greimas.

De fato, desde que o quadrado semiótico foi proposto na década de 1960, como método textual e ferramenta analítica, o quadrado semiótico tem sido 
amplamente adotado pela análise de repetibilidade de patentes, o que garante ser um método de pesquisa científica (DOMANESCHI, 2017).

Estimado por um certo período, como uma espécie de símbolo da semiótica greimasiana, a primeira elucidação sistemática do quadrado semiótico surge em "Sobre o sentido" (GREIMAS, 1975) no capítulo "O jogo das restrições semióticas", de Greimas e Rastie, conforme citado por Silva (2011), "Compreendese por quadrado semiótico a representação visual da articulação lógica de uma categoria semântica qualquer" (GREIMAS; COURTÉS, 1983, p. 364, apud Silva, 2011).

O quadrado trabalha com as estruturas elementares da significação, associando três categorias de analogias ou de estruturas binárias que servem como instrumento de descrição.

Greimas (1976), ainda de acordo com Silva (2011), no instante em que estabelece sua teoria, os conceitos estruturalistas encontravam-se no apogeu. De tal modo, para idealizar seu esquema, o semioticista parte de uma analogia de oposição binária entre dois termos retomada dos estudos fonéticos e fonológicos então cometidos por nomes como Trubetzkoy, Jakobson e Martinet no contexto do Círculo de Praga: trata-se de uma oposição qualitativa do tipo s1 vs. s2 (como em "dia" vs. "noite"), que formam então os termos contrários. A partir deles, através de uma operação de negação, obtêm-se s1 vs. ${ }^{-}$s2 ${ }^{-}$("não-dia" vs. "não-noite"), em que s1 vs. s1 ("dia" vs. - "não-dia") estão em oposição parecido com privativa, formando o par de termos contraditórios.

Sobrepujando o binarismo, a estrutura em quadratura admite ainda termos de terceira geração, complexo $(\mathrm{S})$ e neutro $(\mathrm{S})$, que correspondem à lógica das oposições participativas, onde termos extensivos (mais vagos) e intensivos (mais precisos), de acordo com significação de Hjelmslev (1975, apud SILVA, 2011), se relacionam. De forma geral, temos, no quadrado semiótico (Figura 3), um aspecto estrutural em que as relações dão sentido aos termos.

$\mathrm{O}$ arranjo final é este: 
Figura- 3 Quadrado semiótico de Greimas.

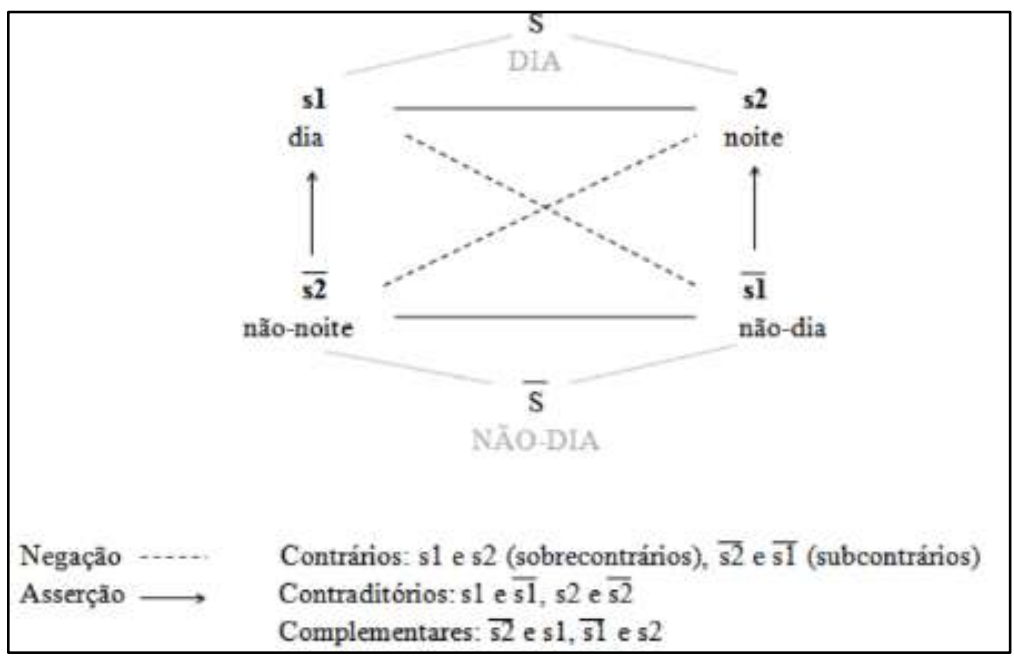

Fonte: GREIMAS \& FONTANILLE, (1993).

Dando prosseguimento à descrição do Percurso Gerativo do Sentido, passase, então, aos níveis narrativo e discursivo.

Segundo Barros (2005), no nível narrativo, a narrativa é organizada do ponto de vista de um sujeito. Nessa etapa, os actantes (papéis narrativos abstratos) percorrem uma sequência canônica, que compreende as fases de manipulação, ação e sanção.

Finalmente, no nível discursivo, a sintaxe e a semântica discursivas, graças à sustentação da enunciação (que vai colocar em discurso as estruturas semionarrativas de superfície), vão acrescentar significação ao discurso, convertendo os actantes em atores, introduzindo o tempo e o espaço (BARROS, $2004 ; 2005)$.

Os procedimentos semânticos do discurso são dois: a tematização e a figurativização. Por meio dos percursos temáticos e figurativos, o enunciador assegura a coerência semântica do discurso e cria efeitos de sentido, sobretudo de realidade.

Os temas e figuras decorrem de determinações sócio-históricas, conscientes ou inconscientes, que trazem para os discursos a maneira de ver e de pensar o mundo de grupos e classes sociais, o que faz da semântica discursiva "o campo da determinação ideológica propriamente dita" (FIORIN, 2004, p. 19).

Segundo Barros (2004, p. 11) são as seguintes as diferentes funções dos procedimentos de figurativização: 
a figurativização assinala, com os temas, a determinação sóciohistórica e ideológica dos discursos; dá aos discursos temáticofigurativos coerência semântica; participa, nos discursos temáticos, das estratégias de persuasão argumentativa, com figuras ocasionais e esparsas; concretiza os temas abstratos e produz efeitos de realidade; cria efeitos de concretização sensorial e dá "corporalidade" ao discurso e às relações entre enunciador e enunciatário; contribui para a produção de efeitos de novidade e criatividade estética, para dar prazer estético ao destinatário e para que enunciador e enunciatário partilhem instantes de "perfeição".

Segundo Pessôa (2013), embora o sentido do texto dependa da relação entre os três níveis do percurso gerativo da significação, cada um possui uma gramática autônoma, o que torna possível observá-los separadamente. Na presente pesquisa, no que tange ao plano do conteúdo, o foco das análises será no nível discursivo do corpus, em especial nos procedimentos da semântica discursiva: a tematização e a figurativização.

Em Semântica estrutural, Greimas (1976, p. 15) avaliava "a percepção como o espaço não linguístico onde se situa a inquietação da significação". Ainda que ele certifique que a percepção é correspondente ao processo de significação, define não se ocupar momentaneamente. Assim, no começo a semiótica cultivava uma separação entre interior (linguístico) e exterior (sensível) no processo de significação, dando preferência ao linguístico (CORTINA; MARCHEZAN, 2004. p. 418).

Entretanto, com o passar do tempo há uma dissolução dessa oposição, quando se readquirem os princípios fenomenológicos para abordar do tema das paixões.

Com esse retorno da fenomenologia, o corpo que, percebe e sente, na investigação do sentido, ganha importância (CORTINA; MARCHEZAN, 2004).

O corpo (instância proprioceptiva) passa a ser aceito como instância produtora de sentido, pois é o espaço onde se dá a intervenção de semiose, em que o plano do conteúdo (de origem interoceptiva) tem relação com o plano da expressão (de origem exteroceptiva). Interoceptividade se pauta com as sensações, corresponde ao mundo interior, cognitivo e emocional do sujeito. Exteroceptividade, às percepções (associadas ao mundo exterior pelos sentidos). Cabe à proprioceptividade fazer o caminho interligando um ao outro (CORTINA; MARCHEZAN, 2004). 
No que tange ao plano da expressão, a presente dissertação fará uso das categorias propostas por Teixeira (2008), em especial, as categorias cromática, eidética e topológica (Tabela 1).

Tabela 1- Categorias do plano de expansão.

\begin{tabular}{|c|c|}
\hline CROMÁTICA & EIDÉTICAS \\
\hline Combinações de cores & Relações entre formas \\
\hline $\begin{array}{c}\text { puro vs. mesclado } \\
\text { brilhante } v s . \text { opaco } \\
\text { saturado } v s . \text { não saturado } \\
\text { claro } v s . \text { escuro } \\
\text { etc. }\end{array}$ & $\begin{array}{c}\text { côncavo } v s . \text { convexo } \\
\text { curvilíneo } v s \text {. retilíneo } \\
\text { verticalidade } v s \text {. diagonalidade } \\
\text { arredondado } v s \text {. pontiagudo } \\
\text { etc. }\end{array}$ \\
\hline TOPOLÓGICAS & MATÉRICAS \\
\hline $\begin{array}{c}\text { Posição e orientação das formas no } \\
\text { movimento do espaço }\end{array}$ & Efeitos obtidos com a materialidade \\
\hline $\begin{array}{c}\text { englobante } v s \text {. englobado } \\
\text { alto } v s \text {. baixo } \\
\text { central } v s \text {. periférico } \\
\text { esquerdo } v s \text {. direito } \\
\text { etc. }\end{array}$ & $\begin{array}{c}\text { pinceladas } \\
\text { contidas } v s . \text { soltas } \\
\text { rarefeitas } v s . \text { saturadas } \\
\text { tinta diluída } v s \text {. pastosa } \\
\text { encorpada } v s \text {. lisas } \\
\text { suporte } \\
\text { rugoso } v s . \text { liso } \\
\text { com relevo } v s . \text { sem relevo } \\
\text { etc. }\end{array}$ \\
\hline
\end{tabular}

Fonte: Tabela adaptada de TEIXEIRA, (2008). 


\section{Procedimentos Metodológicos}

A metodologia utilizada para a construção da presente dissertação foi a pesquisa documental qualitativa sob a perspectiva da semiótica discursiva de linha francesa. A delimitação do presente estudo é espaço-temporal, pois analisa a comunicação da Nissan Motors, apenas no Brasil, no período de janeiro a Agosto de 2020 .

Neste ponto da dissertação é importante destacar o envolvimento da autora com a organização, para que o leitor possa entender o contexto do acesso às informações da empresa e a perspectiva da analista. Como funcionária da Nissan Motors do Brasil, há 6 anos na área de planejamento estratégico da América Latina, a autora da dissertação identificou a necessidade de explorar e analisar a comunicação interna na supracitada empresa, com o objetivo de colaborar para melhores práticas de comunicação dentro da organização no período da pandemia.

A coleta de dados para o presente trabalho se deu por meio de peças de comunicação interna recebidas pela própria autora, na forma de e-mail marketing para funcionários e de comunicação setorial, além de consulta ao acervo da empresa. A área de Comunicação Interna da Nissan Brasil sempre foi ativa e o $e$ mail marketing uma das principais ferramentas de informação para o público interno de colaboradores.

Com a perspectiva de embasar e orientar os protocolos metodológicos necessários, analisou-se os dados segundo as três fases indicadas dos procedimentos metodológicos da análise de conteúdo, que tem um caráter basicamente qualitativo, ainda que possa se utilizar de parâmetros estatísticos para amparar as interpretações dos dados da comunicação. (BARDIN, 2011; DELLAGNELO e SILVA, 2005).

No momento que precede a análise, realizou-se a organização e preparação do corpus do trabalho, através da análise prévia minuciosa das 26 peças de comunicação organizacional da Nissan Brasil, autorizadas pela organização.

Como passo seguinte, fez-se a exploração e mapeamento inicial do material disponível. Assim sendo, as peças de comunicação interna foram renomeadas, enumeradas e listadas numa planilha de controle para facilitar o acesso e a consulta durante o processo de análise. 
Por fim, baseado na interpretação, na qual buscou-se estabelecer vínculos, contradições e tentativas de compreensão do material, estabeleceu-se um recorte de três fases distintas da comunicação interna da Nissan Brasil no período de análise.

Dessa forma, as peças de comunicação selecionadas foram segmentadas de acordo com a fase referente ao estudo. Optou-se pela análise de peças de comunicação interna de e-mail marketing categorizados na tabela 2 de acordo com o desenvolvimento da pesquisa.

O processo de análise e de categorização baseou-se nos procedimentos de tematização e de figurativização (semântica discursiva do percurso gerativo do sentido; plano do conteúdo) e nas categorias cromática, eidética e topológica (plano da expressão) do discurso estudado.

Tabela 2- Distribuição do corpus por período.

\begin{tabular}{|c|c|}
\hline \multicolumn{2}{|c|}{ FASE DA ANÁLISE } \\
\hline Período & $\begin{array}{c}\text { Número de peças de comunicação } \\
\text { interna analisadas }\end{array}$ \\
\hline $\begin{array}{c}\text { 1. Período de Pré-Pandemia: "Quebrando a } \\
\text { formalidade" }\end{array}$ & 6 \\
\hline 2. Período agudo da Pandemia: "Construindo \\
Conexões" & 6 \\
\hline 3. Período de retomada corporativa "Um novo começo" & $\mathbf{2 6}$ \\
\hline TOTAL & 6 \\
\hline
\end{tabular}

Fonte: Autoria Própria, (2020). 


\section{A Nissan Motors do Brasil}

A Kwaishinsha Motor Car Works foi fundada por Masujiro Hashimoto em 1911, seu primeiro carro, o DAT, foi produzido em 1914.

Somente em 1951, chegaram os primeiros Nissan, caminhões, importados do Japão e distribuídos aqui por Mario Barros para a Amaral SA de São Paulo.

Em meados da década de 1950, a Varam Motores assumiu a representação da marca no país, com um projeto de construir uma fábrica, para a produção de 3000 mil peças por ano, mas o projeto não saiu do papel e a Nissan sumiu do roteiro brasileiro por muitos anos (NISSAN MOTORS CORPORATION, 2020).

Apenas em 2000, após assumir a importação e comercialização de seus produtos no mercado interno, a Nissan escolheu o Brasil como base estratégica para construir sua estrutura no Mercosul, sendo reforçada em 2001 com a aliança com a Renault, que passou a prestar apoio local à Nissan para consolidar a sua estratégia de expansão neste mercado. (NISSAN RELEASE, 2020).

A inauguração de uma fábrica de veículos comerciais em São José dos Pinhais, no Paraná, em dezembro de 2001, foi a primeira fábrica conjunta da Aliança no mundo a começar a produzir a picape Nissan Frontier e o veículo utilitário Nissan Xterra em 2002, e outros modelos da Aliança (NISSAN RELEASE, 2020).

Composta por veículos importados e modelos nacionais produzidos pelo setor de veículos comerciais, a Nissan conquistou a preferência dos brasileiros, onde em 2011, anunciou um investimento de 2,6 bilhões de reais, um passo importante na construção do Parque Industrial de Resende, no Estado do Rio de Janeiro (NISSAN RELEASE, 2020).

O Complexo Industrial de Resende foi inaugurado em abril de 2014, com fábricas de automóveis e motores. A unidade veicular tem ciclo completo de produção, incluindo unidades de estamparia e injeção e pintura de peças plásticas, e é considerada como uma das mais modernas e sustentáveis do mundo.

Assim, a empresa, que em 2010 contava com 200 funcionários no país, hoje conta com mais de 2.000 funcionários diretos. Eles são divididos entre:

- Sede da Nissan Brasil, no Rio de Janeiro;

- Complexo Industrial e Centro de Armazenamento e Distribuição de Peças, em Resende (RJ); 
- Escritório com foco na área comercial, em São Paulo;

- Centro de Treinamento, em Jundiaí (SP);

- Áreas de Engenharia e Compras, em São José dos Pinhais (PR).

Foi a patrocinadora dos Jogos Olímpicos e Paralímpicos Rio 2016, e o carro do revezamento da tocha, passando por mais de 300 cidades de diferentes regiões do país, em uma viagem de 90 dias (NISSAN RELEASE, 2020).

A empresa também criou o Instituto Nissan, braço de responsabilidade social e sustentabilidade da empresa no país. Além disso, a empresa mantém desde 2012, um grupo de atletas dos esportes olímpicos e paralímpicos, o Team Nissan, que vem conquistando centenas de medalhas para o esporte brasileiro.

A empresa também avança com o compromisso de desenvolver o ciclo completo da mobilidade elétrica no Brasil. Como em outros países, a empresa firmou uma série de convênios com importantes instituições.

Com a Universidade Federal de Santa Catarina (UFSC), por exemplo, estuda soluções futuras para baterias usadas para veículos elétricos, já com o Parque Tecnológico Itaipu e o Instituto de Tecnologia Aplicada e Inovação, a missão é desenvolver postos de recarga de veículos e sua integração ao sistema energético nacional.

Ainda com o Instituto de Pesquisas Energéticas e Nucleares (IPEN), desenvolve um estudo sobre o uso do bioetanol como opção para a eletro mobilidade (NISSAN RELEASE, 2020).

Foi a pioneira em usar o sistema de inteligência artificial chatbot para atender clientes em seu site oficial, com ações como a criação do Nissan Customer Innovation Hub, uma consultoria digital da marca treinada para atender o cliente de forma ágil e precisa, o lançamento do página oficial no Mercado Livre e adoção do WhatsApp via Bot e com inteligência artificial para agendamento de test drive de clientes (NISSAN RELEASE, 2020).

Em 2020, a Nissan Brasil completa duas décadas de operação oficial no país, evoluindo da importação de automóveis, para se solidificar como fabricante nacional de automóveis e motores 


\section{Análise}

Conforme descrito no referencial teórico do trabalho, para fluxos de comunicação formal ou informal, seja internamente ou fora da organização, destaca-se que é necessário desenvolver a capacidade de identificar, coletar, filtrar e compilar informações. Internamente, os fluxos de informação revelam a estrutura do projeto e planos de ação da organização. Portanto, é importante que essas informações cheguem às partes interessadas de forma consistente, transparente e rigorosa para que todas as áreas entendam tais informações e objetivos de comunicação sejam alcançados (WOODRUFF et al., 1996).

Kotler e Armstrong (2003, p. 369) afirmam que o processo de construção de um plano de comunicação de marketing ocorre em seis etapas, consistindo em estratégias para a criação de um meio de comunicação e promoção, sendo, “identificar o público-alvo, determinar os objetivos da comunicação, elaborar a mensagem, escolher a mídia pela qual a mensagem será transmitida, selecionar a fonte da mensagem e coletar a realimentação." Ainda segundo os autores, a ferramenta do $e$-mail marketing compõe um plano de Comunicação Integrado onde o objetivo é se comunicação de forma eficiente com o público interno organizacional.

Esta ferramenta propõe contatos diretos com um indivíduo que foi cuidadosamente definido como alvo, com o objetivo de obter resposta imediata e cultivar relacionamentos duradouros, visando a comunicação direta com o consumidor específico.

A área de Comunicação Interna da Nissan Brasil sempre foi ativa e o e-mail marketing um dos seus principais canais de informação para o público interno de colaboradores.

A seguir faz-se a análise de peças informativas de comunicação interna da Nissan Brasil, de acordo com a análise semiótica em três períodos distintos da Pandemia do COVID-19, a saber: período pré-pandemia ("quebrando a formalidade"), período agudo da pandemia (“construindo conexões") e o período de retomada coorporativa na pandemia ("um novo começo"). 


\subsection{Quebrando a formalidade: período pré-pandemia}

A mensagem de comunicação interna da Nissan Brasil sempre teve como foco o direcional informativo, relatando mudanças organizacionais, direcionais de expediente, carga diária de trabalho, regra de conduta corporativa, direcional estratégico e visão de planejamento do alto board. A linguagem era objetiva e na maior parte das vezes reforçava a posição hierárquica presente na comunicação da organização, redigida pelo presidente da empresa na América Latina, o porta-voz da mensagem e a pessoa que assina a comunicação aos demais colaboradores. Em termos de imagem, a ilustração das peças de comunicação interna traz a identidade da marca Nissan através do uso da paleta de cores vermelho, branco ou azul como institucional da América Latina.

Fiorin (1988) destaca que é no nível da semântica discursiva onde as determinações sócio-históricas e ideológicas ocorrem de forma mais cabal. Os temas e conteúdos semânticos tratados de forma abstrata, as figuras e o investimento semântico-sensorial dos temas, constituem a semântica discursiva e asseguram a coerência semântica, temática e figurativa do discurso.

Os temas e figuras são determinados sócio historicamente e trazem para os discursos o modo de ver e de pensar o mundo de classes, grupos e camadas sociais, garantindo assim o caráter ideológico desses discursos.

De acordo com o acervo disponibilizado pela empresa, pode-se notar que as imagens apresentavam um caráter mais básico, com uma tentativa de ilustração didática, mas sem ser lúdica. Transparecendo, então, uma conotação mais formal.

A análise da peça de comunicação interna, enviada aos funcionários por $e$ mail marketing no dia 28 de janeiro de 2020, (Figura 4) ilustra o tipo de comunicação que a organização veiculava no período Pré-COVID-19.

A mensagem principal é a de anúncio de mudança de cargo no quadro organizacional da Nissan Brasil. Em termos de estrutura de diagramação, pode-se notar "rigidez" que é fixada por um cabeçalho e rodapé que são padronizados.

A linguagem é formal e hierárquica. As cores remetem ao tradicionalismo, trazendo o vermelho da marca Nissan e não há flexibilização de nuances.

Pode-se destacar que na publicação da Figura 4, a Nissan Brasil busca comunicar mudanças em sua estrutura organizacional. Como o autor ilustra, nota- 
se um modo de ver e pensar o mundo de classes, com a hierarquização das funções e cargos assim descritos.

De acordo com a categorização dos planos de conteúdo e expressão (TEIXEIRA, 2008):

- Cromática: a predominância da cor vermelha (identidade visual da empresa) em alinhamento com o padrão e diretrizes globais. Não há identificação de flexibilização de cores, mesmo dentro da mesma paleta de tons.

- Eidética: uso de formas retas, o que indica rigidez e formalidade.

- Topológica: proporcionalidade no layout, com a massa de texto bem distribuída para ocupar a superfície da peça de comunicação interna.

- Textual: A escrita é formal e hierárquica.

Figura- 4 Comunicação interna publicada em 23 de janeiro de 2020.

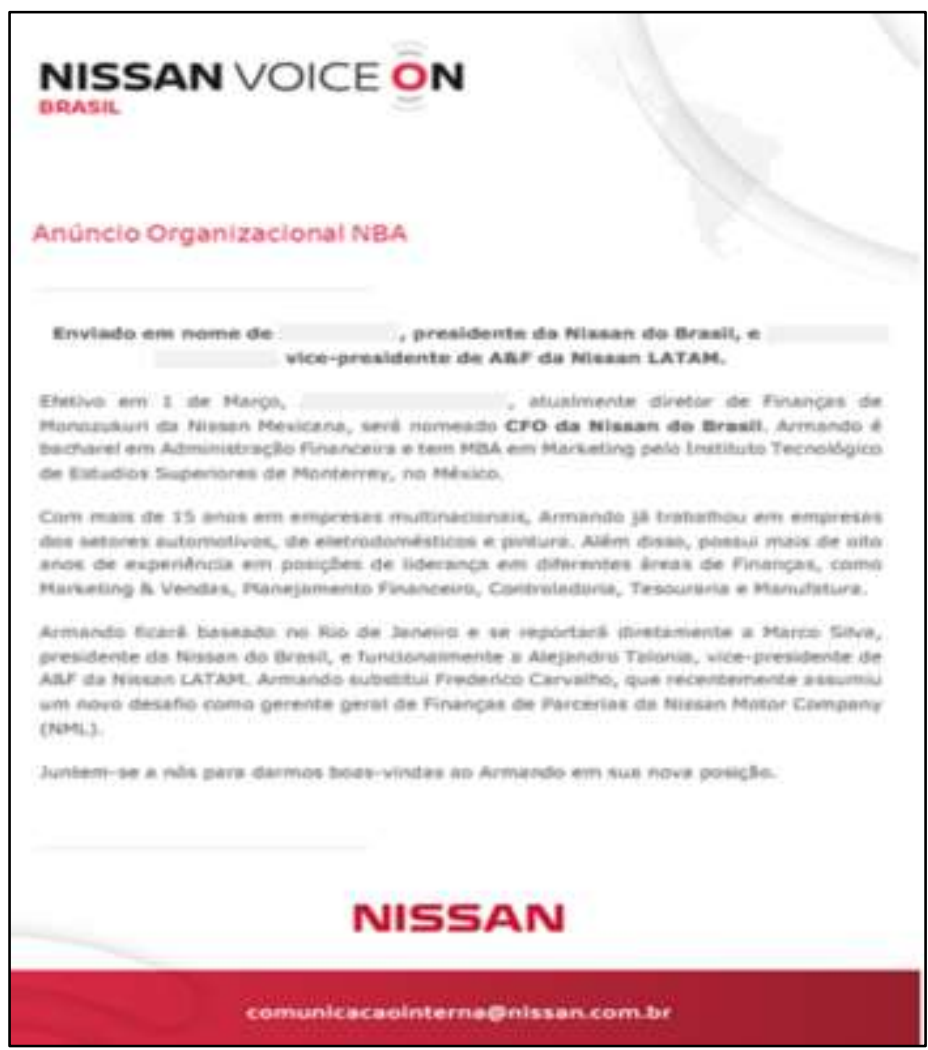

Fonte: Nissan Brasil, (2020).

A peça de comunicação interna publicada no dia 10 de fevereiro de 2020 (Figura 5) também é um exemplo de comunicação PRÉ-COVID-19.

Nela, pode-se observar uma tentativa de comunicação interna organizacional, mais ilustrativa e didática. Ainda que de forma sutil, pode ser notar uma 
flexibilização do cabeçalho e rodapé. Há a presença de símbolos ilustrativos, na tentativa de implementar um tom mais didático à peça de comunicação.

Figura- 5 Comunicação interna publicada em 10 de fevereiro de 2020.

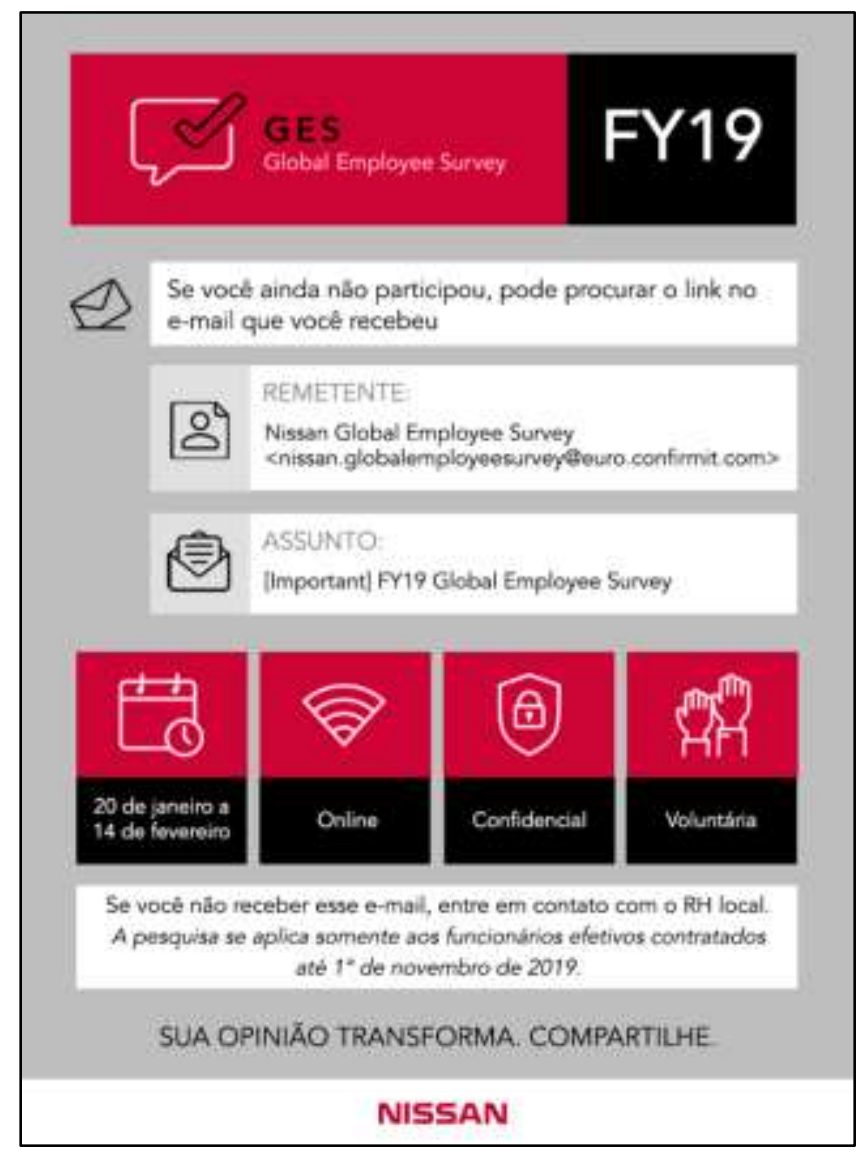

Fonte: Nissan Brasil, (2020).

A abordagem linguística é mais inclusiva e menos hierárquica, utilizam-se palavras chaves como se pode identificar na citação, utilizando a frase: "Sua opinião transforma, compartilhe". Assim a análise descreve-se como:

- Cromática: a predominância da cor vermelha. Nesse contexto, se identifica a flexibilização por meio da inserção de novas cores, como o preto, o cinza e o branco, porém ainda com características formais;

- Eidética: uso de linhas e formas retas;

- Topológica: Uso de símbolos no layout, com a massa de texto e as imagens bem distribuídas para ocupar a superfície das peças de comunicação interna. Preencher todas as lacunas do texto traz o valor da "transparência" da organização;

- Textual: A escrita é mais inclusiva e menos hierárquica. 
A implementação do estado de Pandemia de COVID-19 no Brasil, começou em 20 de fevereiro de 2020, após a confirmação de que um homem de 61 anos, que voltou da Itália deu positivo para SARS-CoV-2, que causa COVID-19 ${ }^{3}$.

A partir da instauração desse contexto, algumas ações foram praticadas como parte de um plano de contingência, discutido no comitê de risco organizacional da Nissan Brasil. Dentre elas, medidas emergenciais como:

- implementação de home office para $100 \%$ da força de trabalho em março de 2020;

- férias coletivas para os funcionários das unidades produtivas em abril de 2020;

- $\quad$ redução da jornada de trabalho para os funcionários que permaneceram com decréscimo salarial de $20 \%$ também em abril e maio de 2020;

- $\quad$ suspensão contratual com afastamento pelo governo de alguns funcionários, devido à redução de produção e encolhimento das vendas em maio de 2020.

A comunicação também foi reforçada, enfatizando as novas regras sanitárias e direcionando educacionalmente os colaboradores, sobre a importância de lavar bem as mãos e o uso de máscara e álcool gel.

Além disso, passou a ser constante a publicação de e-mail com informações atualizadas e importantes sobre o vírus, tais como: o que é, como é transmitido, como prevenir, etc. (Figura 6).

Sendo assim, a análise semiótica da comunicação interna do dia 12 de fevereiro de 2020 de acordo com os planos de conteúdo e expressão ocorre da seguinte maneira:

- Cromática: mais uma vez nota-se a predominância da cor vermelha (identidade visual da empresa). Não há identificação de flexibilização de cores ou tons, mesmo dentro da mesma paleta cromática;

- Eidética: uso de formas retas, o que indica rigidez e formalidade;

- Topológica: proporcionalidade no layout, com a massa do texto bem distribuída para ocupar a superfície do elemento de comunicação interna, visando passar a mensagem que está abordando de modo completo os

\footnotetext{
3 Fonte: https://agenciabrasil.ebc.com.br/saude/noticia/2020-03/covid-19-governo-declara-
} transmissao-comunitaria-em-todo-o-pais 
pontos sobre a temática, de forma clara, transparente e ética com os seus colaboradores;

- Textual: a escrita é formal e hierárquica. Indicação de perguntas e respostas de modo a elucidar o funcionário sobre questões relacionadas ao tramite operacional e o Coronavirus.

Figura- 6 Comunicação interna publicada em 12 de fevereiro de 2020.

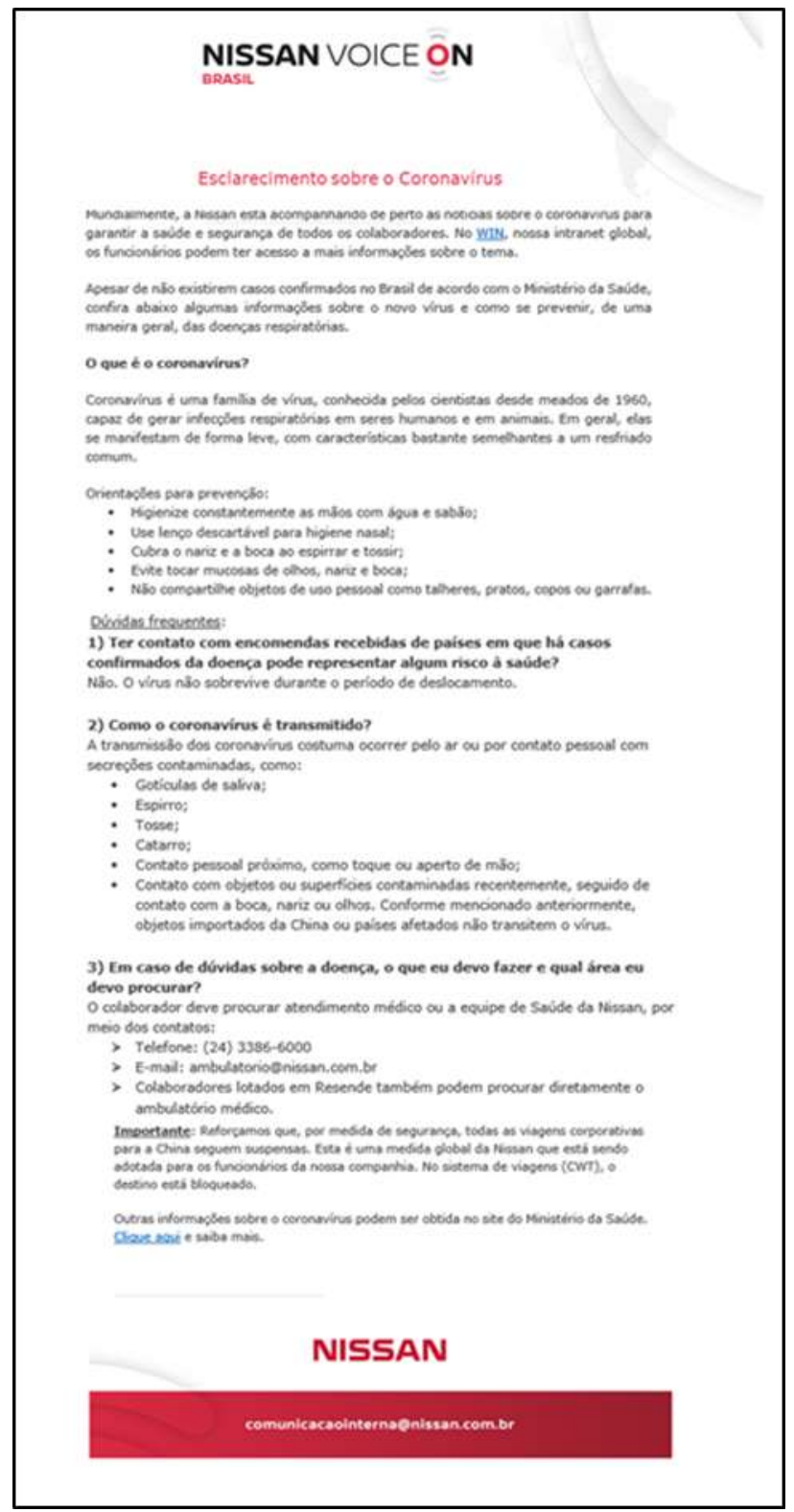

Fonte: Nissan Brasil, (2020).

Contudo, um plano de comunicação interna também foi desenvolvido para gerenciar em termos de informação a crise do COVID-19, o que foi essencial para garantir um clima organizacional mais equilibrado. 
Logo, a Figura n..$^{\circ}$, mostra a inconstância da comunicação deste período Pré COVID-19. Há uma tentativa de flexibilização, que é exercida em alguns temas, porém quando a notícia é de alta relevância e de padrão global, mais uma vez o padrão rígido, hierárquico é retomado.

Diferentemente da peça anterior, a comunicação se apresenta de forma padrão, com cores discretas e comunicação formal, sem ilustrações ou palavras de efeito passional. Há uma preocupação em esclarecer de forma clara e objetiva sobre o Coronavirus, utilizando pontuação específica com frases objetivas.

A análise se dá da seguinte forma:

- Cromática: emprego da cor azul (identidade visual da empresa). Há identificação de flexibilização de cores, dentro da mesma paleta de cores;

- Eidética: apresenta formas curvilínea no canto superior direito, em alusão ao delicado, linhas suaves;

- Topológica: proporcionalidade no layout, com a massa do texto bem distribuída para ocupar a superfície do elemento de comunicação interna;

- Textual: a escrita é formal e objetiva, reforçando os cuidados e como proceder em caso de dúvidas.

Figura- 7 Comunicação interna publicada em 16 de março de 2020.

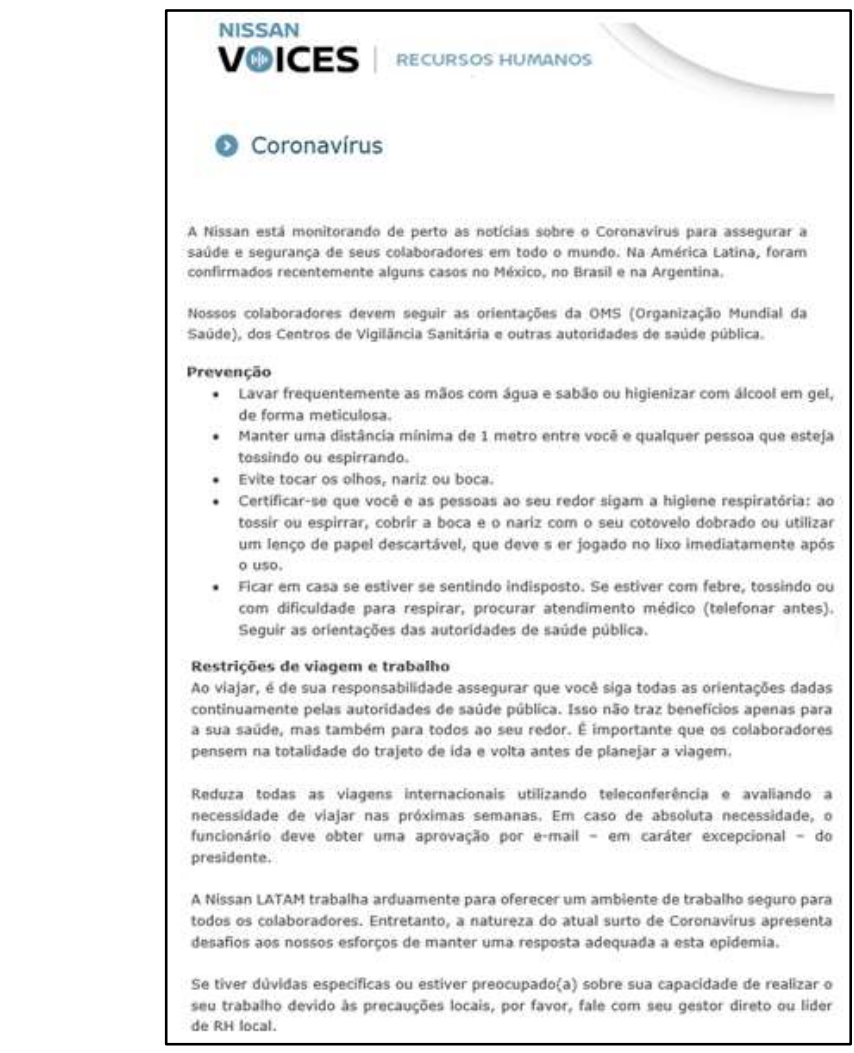

Fonte: Nissan Brasil, (2020). 
Portanto, na primeira fase de comunicação interna estabelecida nesta pesquisa, pode-se dizer que o tema abordado é prioritariamente aquele relacionado às rotinas organizacionais: alterações de expediente, políticas de conduta, treinamento corporativos, mensagens de direcional estratégico, entre outras temáticas, com destaque para os subtemas planejamento, expediente, condutas, etc.

A figurativização se dá por meio de figuras padrão da comunicação corporativa, como exemplifica cabalmente a Figura 8, que apresenta grafismos que remetem à ícones de informática para representar as figuras de rotina/calendário e conectividade/internet, por exemplo.

Figura- 8 Comunicação interna publicada em 17 de março de 2020.

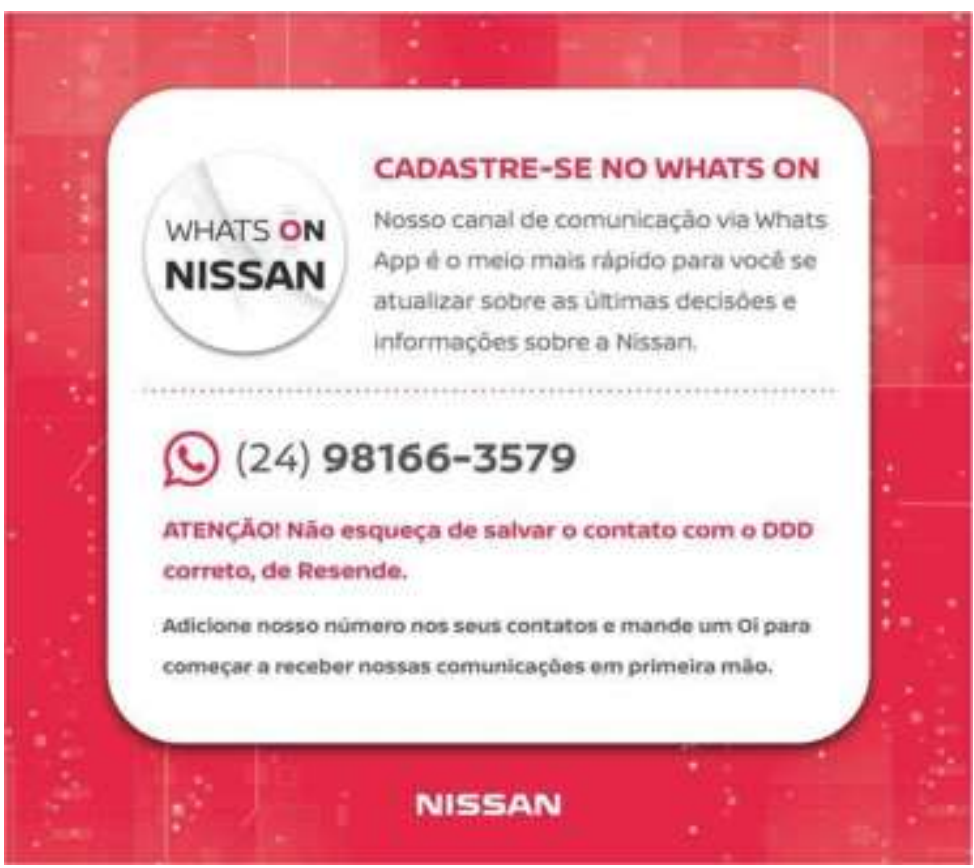

Fonte: Nissan Brasil, (2020).

Do ponto de vista das categorias dos planos de conteúdo e expressão (TEIXEIRA, 2008), observa-se:

- Cromática: a predominância da cor vermelha (que remete à identidade visual da empresa) em alinhamento com o padrão e diretrizes globais. Nesse contexto, identifica-se a flexibilização de inserção de novas nuances da paleta de cor escolhida;

- Eidética: uso de formas arredondadas, o que traduz mudança de comportamento visual e informalidade;

- Topológica: proporcionalidade nos layouts, poucas frases; 
- Textual: a escrita é informal e acolhedora. Mostrando a mudança no tom da comunicação através do uso de aplicativo de comunicação e palavras informais como "você" e "oi".

Outro exemplo de mudança na comunicação interna é a Figura 9. A utilização de vídeos explicativos, marca a mudança de comunicação da empresa com os funcionários e a estende para familiares, com a preocupação de informar corretamente como fazer a prevenção do COVID-19.

Figura- 9 Comunicação interna publicada em 17 de março de 2020.

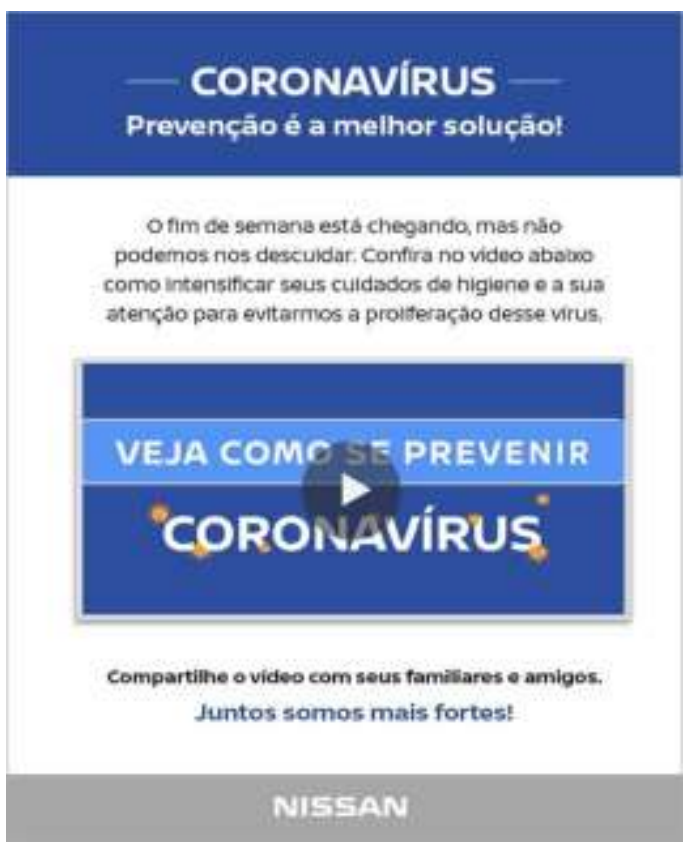

Fonte: Nissan Brasil, (2020).

\subsection{Construindo Conexões: período agudo da pandemia}

No dia 18 de março de 2020, a Nissan Brasil oficializa o home office para a área administrativa. Essa comunicação é um divisor do posicionamento organizacional. Até esse momento havia uma estrutura padronizada de veiculações com pequenas tentativas de inovação e flexibilização de conteúdo.

Porém, com o aumento do número de caso do COVID-19, a empresa foi obrigada a agir de forma rápida, adaptando a sua forma de comunicação, linguagem e estética, para impactar e informar de modo eficiente os seus colaboradores.

O movimento foi veloz, o que mostrou uma grande adaptabilidade organizacional às situações de crise como a Pandemia. Inicialmente, a empresa informou sobre os casos no cenário internacional, iniciando ações de restrição 
como: cancelamento de viagens corporativas, realizando a permissão de retorno dos expatriados para a sua terra natal, substituição de reuniões presenciais por reuniões remotas, controle através da área de saúde e segurança da temperatura e estado de saúde dos colaboradores nas unidades produtivas e prédios administrativos.

As peças de comunicação interna veiculadas nessa fase aguda, durante o ciclo pandêmico no Brasil, classificamos como mais flexíveis pois através da diagramação, texto e ilustração figurativa traduzem uma maior informalidade e empatia.

Destaca-se que a sensação de flexibilização sinalizada nas peças de comunicação interna abaixo, são identificadas pelas figuras que conotam essa "sensorialidade" descrita por BARROS (2004). A autora cita que essas figuras têm a função de persuadir o destinatário do texto, como um exemplo, modelo, ilustração e outras formas de argumentação.

Nas peças de comunicação interna selecionadas para a análise, verificamos uma conotação de maior informalidade, de uma tentativa de criar um sentimento de pertencimento a um coletivo, de cuidado e de empatia organizacional.

Com o agravamento da Pandemia, a organização foi pressionada pelo contexto social e sanitário a ser mais empática, objetiva e próxima (Figura 10).

A Figura 10 ilustra o redirecionamento de conduta adotada pela a empresa com o e-mail marketing do dia 18 de março de 2020.

Nesse anúncio, a Nissan Brasil oficializa o home office, nota-se uma estrutura de layout ainda rígida marcada por cabeçalho padrão e rodapé, porém a imagem de pessoas no rodapé transmite uma mensagem de empatia, a qual sugere "não estar só e ter pessoas gerindo esse momento de crise".

A análise subjetiva destaca cores neutras, linhas de realce de cores finas, remetendo à neutralidade e equilíbrio. $\mathrm{O}$ destaque em negrito da palavra continuidade, denota afirmação concreta de fato contínuo, dispersando qualquer dúvida sobre a situação futura.

No tocante da análise de acordo com os planos de conteúdo e expressão aplicado por Teixeira (2008) pode-se dizer que:

- Cromática: a predominância da cor azul e nuances da paleta de cor (que remete à identidade visual da empresa);

- Eidética: predomínio do uso de linhas retas, o que traduz formalidade e hierarquia, atenuado por linhas curvas (na imagem das pessoas); 
- Topológica: proporcionalidade no layout, com a massa do texto bem distribuída para ocupar a superfície do elemento de comunicação interna;

- Textual: a escrita é formal, porém, acolhedora. Demonstra preocupação com a continuidade das operações.

Figura- 10 Comunicação interna publicada em 18 de março 2020.

\section{VIISAN}

Atualizaça sobre a situacso do

Coronavirus na América Latina

Prezados colaboradores,

A Nissan está acompanhando de perto as notícias sobre o Covid-19 (Coronavirus) ao redor do mundo para garantir a saúde e segurança dos nossos funcionários e seus familiares. Até o momento, nós não registramos nenhuma confirmação de casos de Coronavirus entre funcionários e colaboradores terceiros.

Independentemente disso, considerando as recomendações dadas pelos governos locais e para contribuir com a contenção da proliferação da pandemia na nossa região, implementaremos o escritório virtual (virtual office) para todos os colaboradores e estagiários a partir de 19 de março. Esperamos que esta medida temporária se estenda até o fim do mês, mas forneceremos atualizações regulares sobre quando poderemos voltar para o escritório.

Pedimos que atentem para o fato que esta medida exclui algumas atividades dentro da Nissan na região, cuja presença física no escritório é essencial para a continuldade do negócio. Se você não tem certeza se isso se aplica a você, ou se você não tem condições de trabalhar de casa, por favor, converse sobre isso com o seu gestor ou o seu HRBP.

Durante este período de virtual office em todas as unidades da região, serão suspensos os serviços do restaurante e de transporte por ônibus fretado da empresa. Será mantido apenas o serviço médico, de limpeza e segurança.

Também pedimos que tenham em mente que o serviço VPN é necessário apenas para acessar os sistemas de informação da empresa. Não é necessário o uso de VPN para acessar o Skype, Zoom e e-mails. Nosso VPN é compartilhado com as equipes dos EUA e do México. Por isso, para assegurar uma melhor performance, pedimos que dê preferência para acessar os sistemas corporativos das 7h da manhã ao meio-dia (GMT-3 horas).

Conforme comunicado anteriormente, todas as viagens internacionais devem ser canceladas e as viagens não essenciais dentro do país devem ser evitadas, assim como os eventos corporativos e reuniões presenciais. Devemos assegurar que estamos seguindo estas medidas simples para reduzir nossa exposição ao vírus.

Estamos atuando para não haver interrupções neste momento de mudança temporária na forma como trabalhamos, para proteger a saúde e segurança de todos os colaboradores, ao mesmo tempo em que continuamos oferecendo um atendimento completo e robusto aos clientes. Agradecemos profundamente o seu apoio e profissionalismo.

Em caso de dúvidas, entre em contato com seu gestor direto ou HRBP.

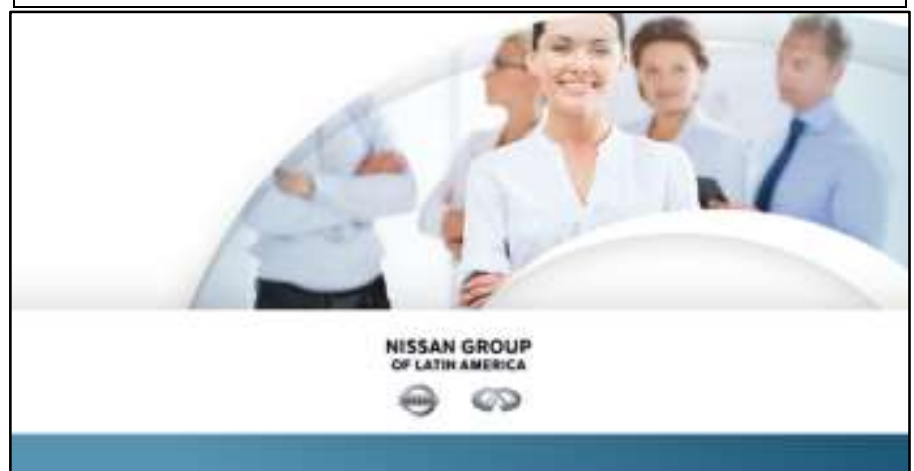

Fonte: Nissan Brasil, (2020). 
Observa-se a mudança de padrão de cores e linhas quando a comunicação é relacionada a temas coorporativos importantes. Na comunicação interna publicada no dia 23 de março de 2020 (Figura 11).

Diferentemente das publicações anteriores o padrão de cor alterna para a cor predominante da empresa de âmbito global, o vermelho. Linhas retas e texto objetivo, com palavras formais, demonstram a formalidade e hierarquização da empresa.

Figura- 11 Comunicação interna publicada em 18 de março 2020.

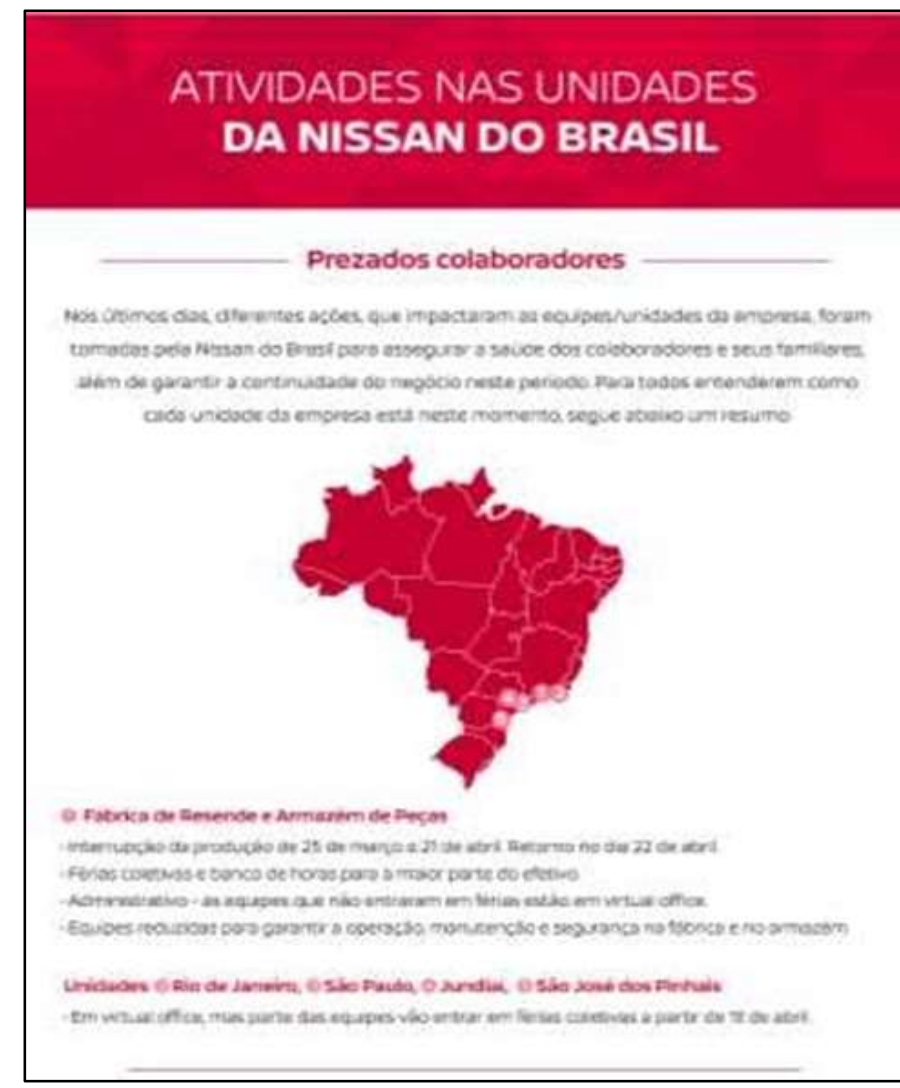

Fonte: Nissan Brasil, (2020).

Assim, segundo Teixeira (2008):

- Cromática: a predominância da cor vermelha (identidade visual da empresa) em alinhamento com o padrão e diretrizes globais;

- Eidética: uso de formas retas, o que indica rigidez e formalidade;

- Topológica: proporcionalidade no layout, com a massa de texto bem distribuídas para ocupar a superfície da peça de comunicação interna;

- Textual: a escrita é formal e hierárquica. Robustez organizacional e hierárquico. 
No período agudo da Pandemia, nota-se uma mudança da narrativa organizacional da Nissan Brasil. Esta mudança demonstra o ápice com a publicação da comunicação interna do dia 27 de março de 2020 (Figura 12).

Figura- 12 Comunicação interna publicada em 27 de março 2020.

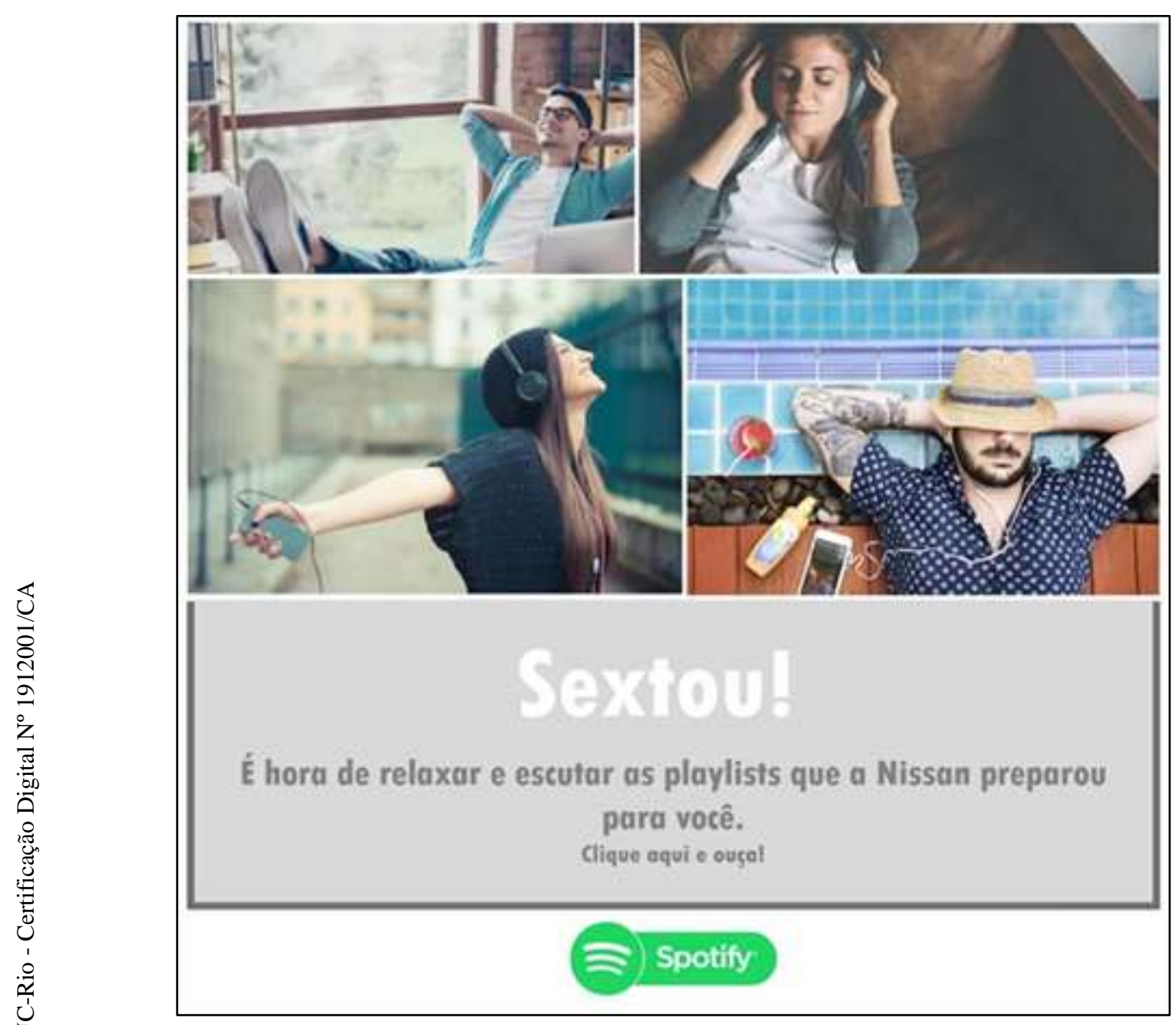

Fonte: Nissan Brasil, (2020).

A utilização não de desenhos, mas de fotos de pessoas reais, a utilização da palavra "sextou" e a playlist de músicas voltadas para os funcionários da Nissan Brasil apresentam uma tentativa de aproximação do relacionamento funcionárioempresa.

Partindo do princípio do plano, segundo as categorias propostas por Teixeira (2008), a figura acima denota:

- Cromática: o momentâneo desaparecimento das cores predominantes da identidade visual da Nissan Brasil;

- Eidética: uso de formas orgânicas e desconexas, o que indica maleabilidade e informalidade; 
- Topológica: o maior espaço dedicado às imagens em detrimento da massa de texto;

- Textual: a escrita é informal e de aproximação. Utilização da palavra "sextou" indica a caracterização de informalidade.

Barros (2004) afirma que as figuras concretizam sensorialmente os temas e dão a eles "corporalidade". Os temas abstratos são "recobertos" por traços semânticos "sensoriais" de cor, de forma, de cheiro, de sons etc. A Figura 12 exemplifica cabalmente este conceito, sendo o ápice da mudança de uma comunicação mais temática, do período pré-pandemia, para uma comunicação mais figurativa.

A figura 13 destaca essa narrativa, a utilização de um discurso mais figurativo evoca o sentimento de pertencimento do funcionário. $\mathrm{O}$ acolhimento utilizado com elementos visuais (cores vivas e figuras), o emprego da frase de chamada "Keep Calm and...", denota a linguagem de argumentação. Segundo Barros (1988 apud TEIXEIRA, 2008), “a argumentação precisa ser revista e considerada como uma estrutura de programas narrativos de busca ou de construção do saber ou de procura de adesão e de confiança”.

Figura- 13 Comunicação interna publicada em 02 de abril 2020.

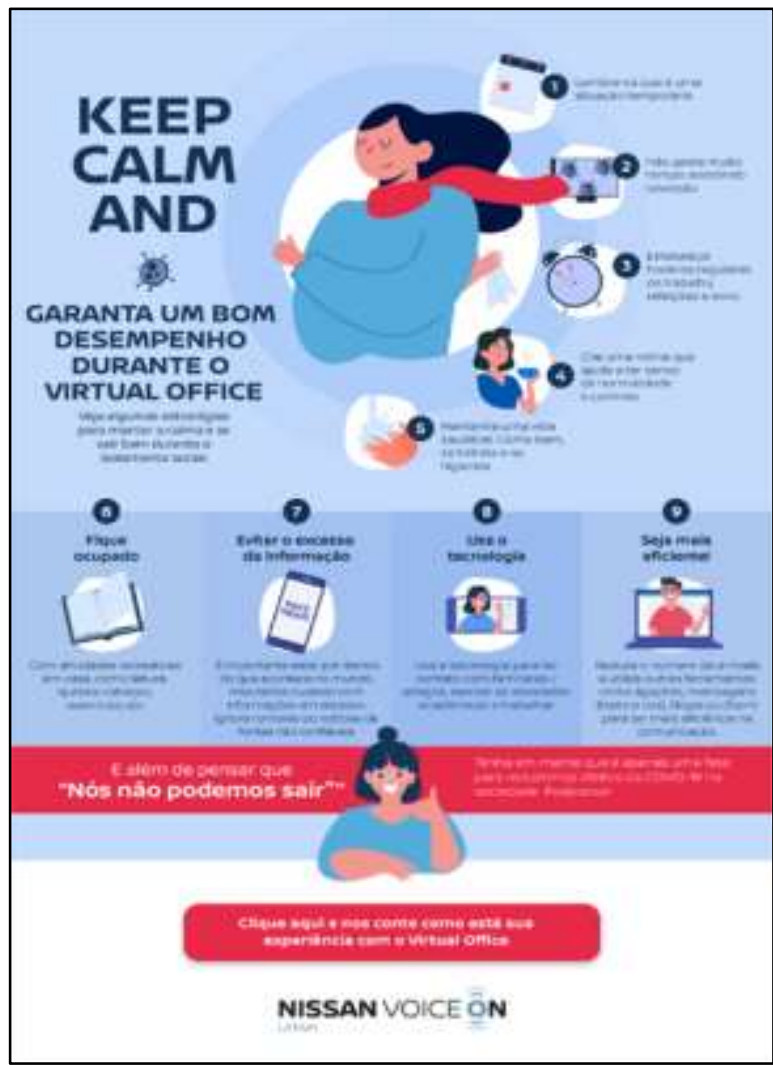

Fonte: Nissan Brasil, (2020). 
A análise da comunicação interna publicada no dia 02 de abril de 2020 (Figura 13), compreende as categorias:

- Cromática: a utilização das cores identitárias da Nissan Brasil (cor vermelha e azul) em alinhamento com o padrão e diretrizes global. Nesse contexto, identifica-se a flexibilização de inserção de novas nuances da paleta de cor escolhida;

- Eidética: uso de linhas arredondadas, o que indica maleabilidade e informalidade;

- Topológica: utilização de figuras distribuídas para ocupar a superfície da peça de comunicação interna em detrimento da massa de texto;

- Textual: a escrita é informal e de aproximação. Utilização da frase "Keep Calm and..." indica a caracterização de informalidade.

Ainda nessa linha, observa-se a comunicação interna do dia 02 de abril de 2020 (Figura 14).

Figura- 14 Comunicação interna publicada em 02 de abril 2020.
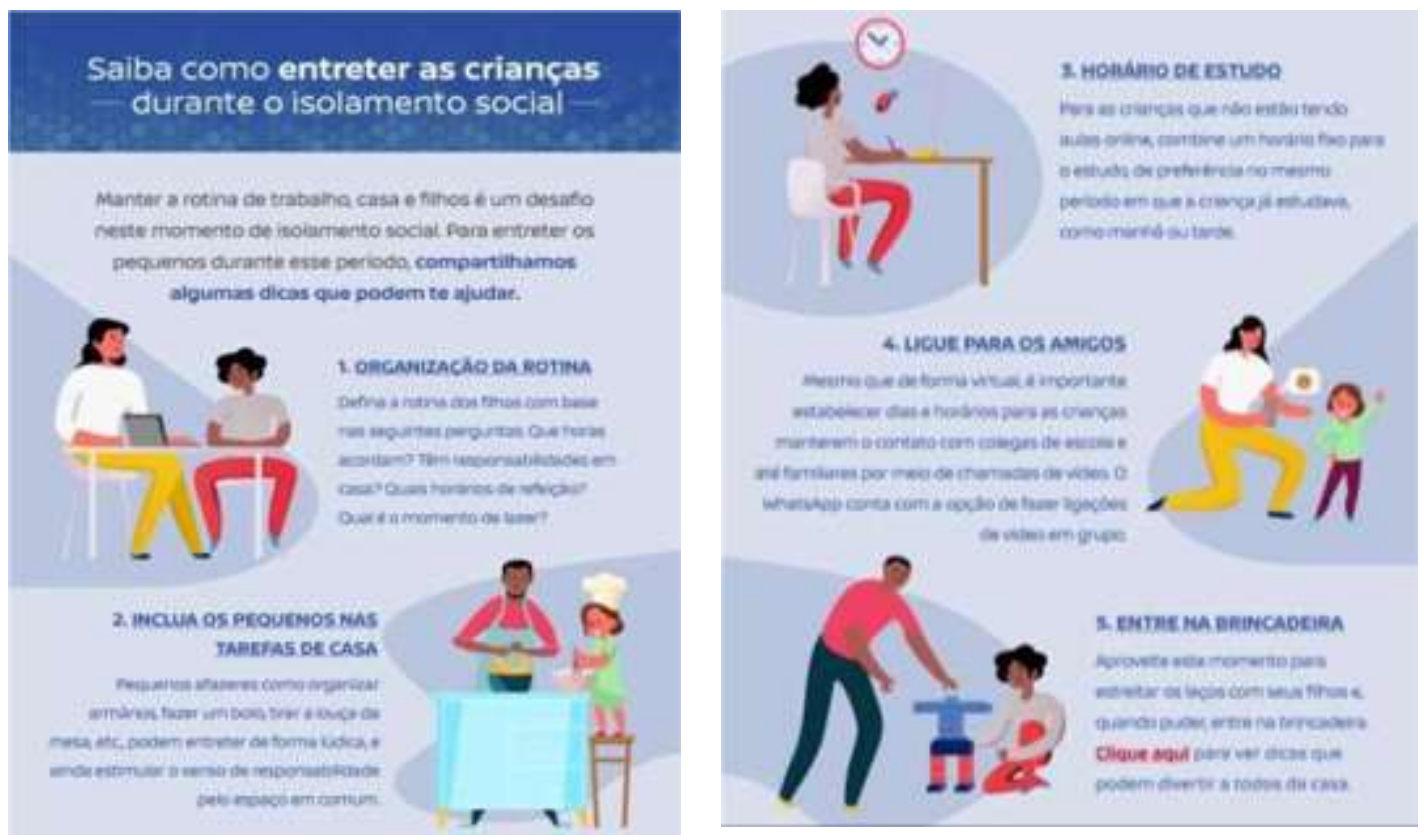

Fonte: Nissan Brasil, (2020).

A predominação de cores vibrantes e uso de figuras ilustrativas, apontam a flexibilização organizacional da empresa. O emprego da linguagem informal, visa ajudar ao colaborador a lhe dar com os desafios do home office.

Após esse anúncio, a Nissan Brasil buscou reforçar a conexão com seus colaboradores, incentivar treinamentos e capacitação, preenchendo assim o 
momento em que grande parte das atividades organizacionais foram "congeladas" ou canceladas.

A peça da Figura 15 ilustra esse movimento da organização. Avaliando assim, inicialmente as peças de comunicação, através da análise semiótica, nota-se em termos de conteúdo que as mensagens têm em comum a estratégia organizacional, que mesmo em período de quarentena, tenta dar continuidade aos negócios, mitigando assim as possibilidades de prejuízo.

De forma linear, a perspectiva ilustrativa tentar ludicamente explicar conceitos simples e ações para não perder a produtividade e não comprometer a rotina laboral.

Figura- 15 Comunicação interna publicada em 09 de abril de 2020.

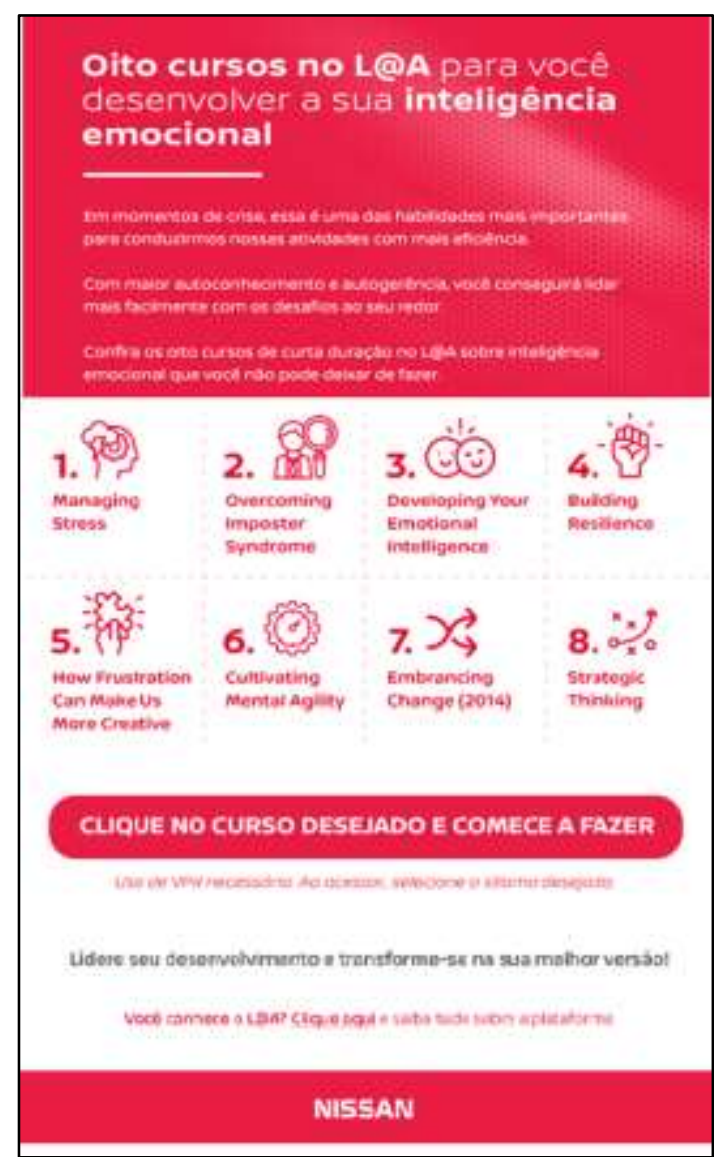

Fonte: Nissan Brasil, (2020).

Neste período a análise configura-se assim:

- Cromática: a predominância da cor vermelha brilhante, estímulo visual;

- Eidética: uso de formas arredondadas, o que traduz mudança de comportamento visual e informalidade; 
- Topológica: proporcionalidade nos layouts, utilização de símbolos;

- Textual: a escrita é informal e acolhedora. Mostra a preocupação da empresa em capacitar seus funcionários, utilizando incentivo comportamental e palavras informais de encorajamento como "você", "lidere" e "transforme".

Analisando sob a ótica do conteúdo, o período pandêmico pode ser sub classificado em duas ações complementares, a primeira, direcionada para o treinamento e capacitação dos funcionários e, a segunda, conexão e criação de vínculo entre funcionários e empresa.

Aprofundando a primeira ação, a de Treinamento e Capacitação, nota-se uma tentativa da organização em prover conteúdos de desenvolvimento aos seus funcionários e preencher, assim, as lacunas de tempo e produtividade ocasionadas pelo novo ambiente de home office.

Diversos conteúdos foram publicados neste período com temática diversa, como: nova dinâmica de trabalho digital, como realizar home office com crianças, como liderar a distância. Essas ações buscavam proporcionar uma maior interação e produtividade da empresa.

Figura- 16 Comunicação interna publicada em 22 de abril de 2020.

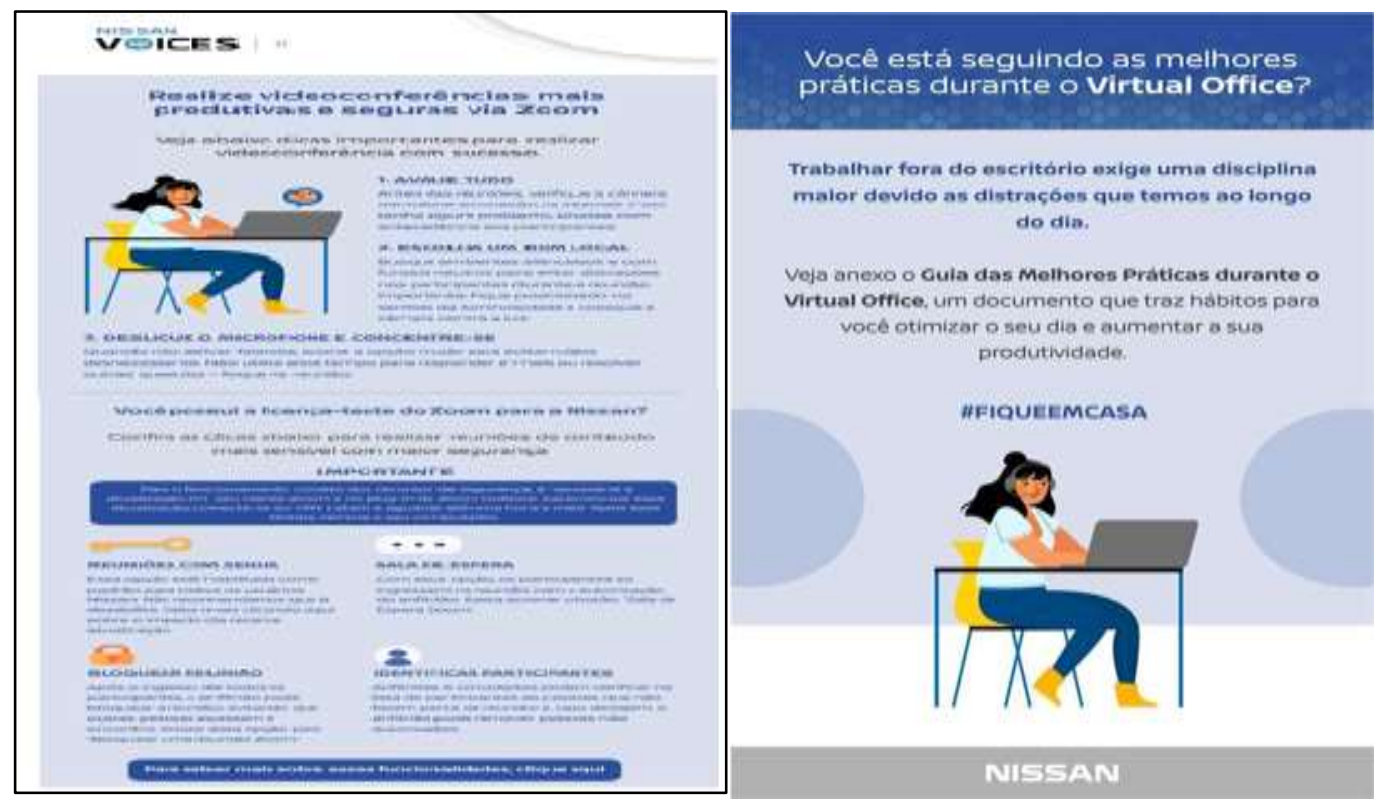

Fonte: Nissan Brasil, (2020).

A utilização de símbolos para ilustrar a peça da Figura 16, reforça a percepção de estímulos visuais e cores vivas para a aguçar os sentidos do destinatário. 
A análise consiste em:

- Cromática: a predominância da cor azul, variedade dos tons da paleta de cores, estímulo visual;

- Eidética: uso de formas arredondadas, o que traduz mudança de comportamento visual e informalidade;

- Topológica: proporcionalidade nos layouts, utilização de símbolos, desenhos;

- Textual: a escrita é formal e acolhedora. Mostra a preocupação da empresa em capacitar seus funcionários.

Reforçando a percepção do colaborador, a segunda mensagem da comunicação interna reitera a mensagem anterior, visando intensificar a aprendizagem de uso do ambiente de trabalho virtual. As cores são sóbrias, com tons de azul, e as linhas arredondadas, porém percebe-se a utilização padrão das linhas no rodapé da imagem que remete o padrão hierárquico no assunto direcionado.

Figura- 17 Comunicação interna publicada em 22 de abril de 2020.

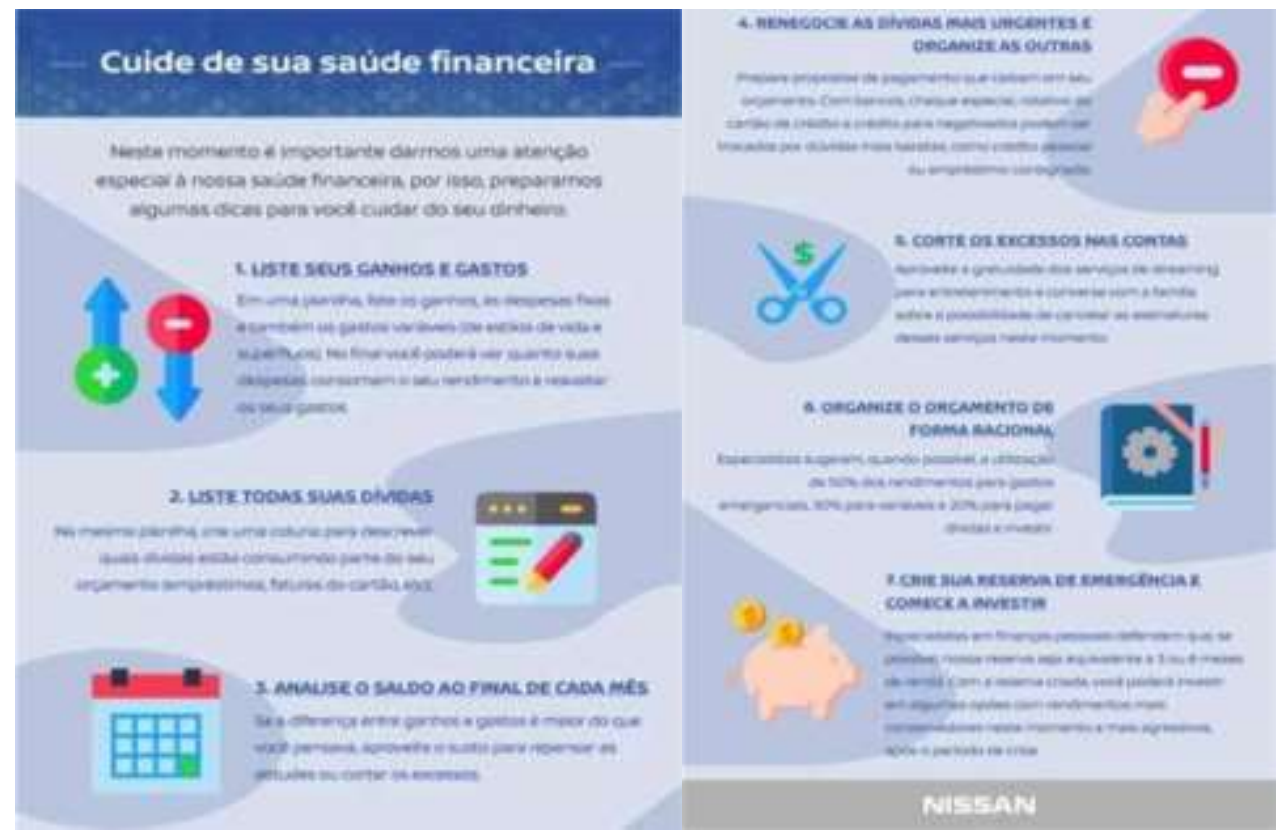

Fonte: Nissan Brasil, (2020).

Percebe-se neste ponto da comunicação interna da Nissan Brasil, a variação de padrão de linguagem figurativa de acordo com o tema a ser tratado. Observando a Figura 17, nota-se a mudança da linguagem por se tratar de um tema mais geral, não ligado a comunicação organizacional da Nissan Brasil. 
A utilização de variação do padrão de cores e linhas arredondadas tem uma conotação menos hierárquica. Sendo assim, analisa-se:

- Cromática: a predominância da cor azul, variedade do tom na paleta de cores, estímulo visual;

- Eidética: uso de formas retas na base, e linhas arredondadas o que indica rigidez organizacional e informalidade;

- Topológica: proporcionalidade no layout, com a massa de texto bem distribuídas para ocupar a superfície da peça de comunicação interna;

- Textual: a escrita é informal e ilustrativa.

Figura- 18 Comunicação interna publicada em 30 de abril de 2020.

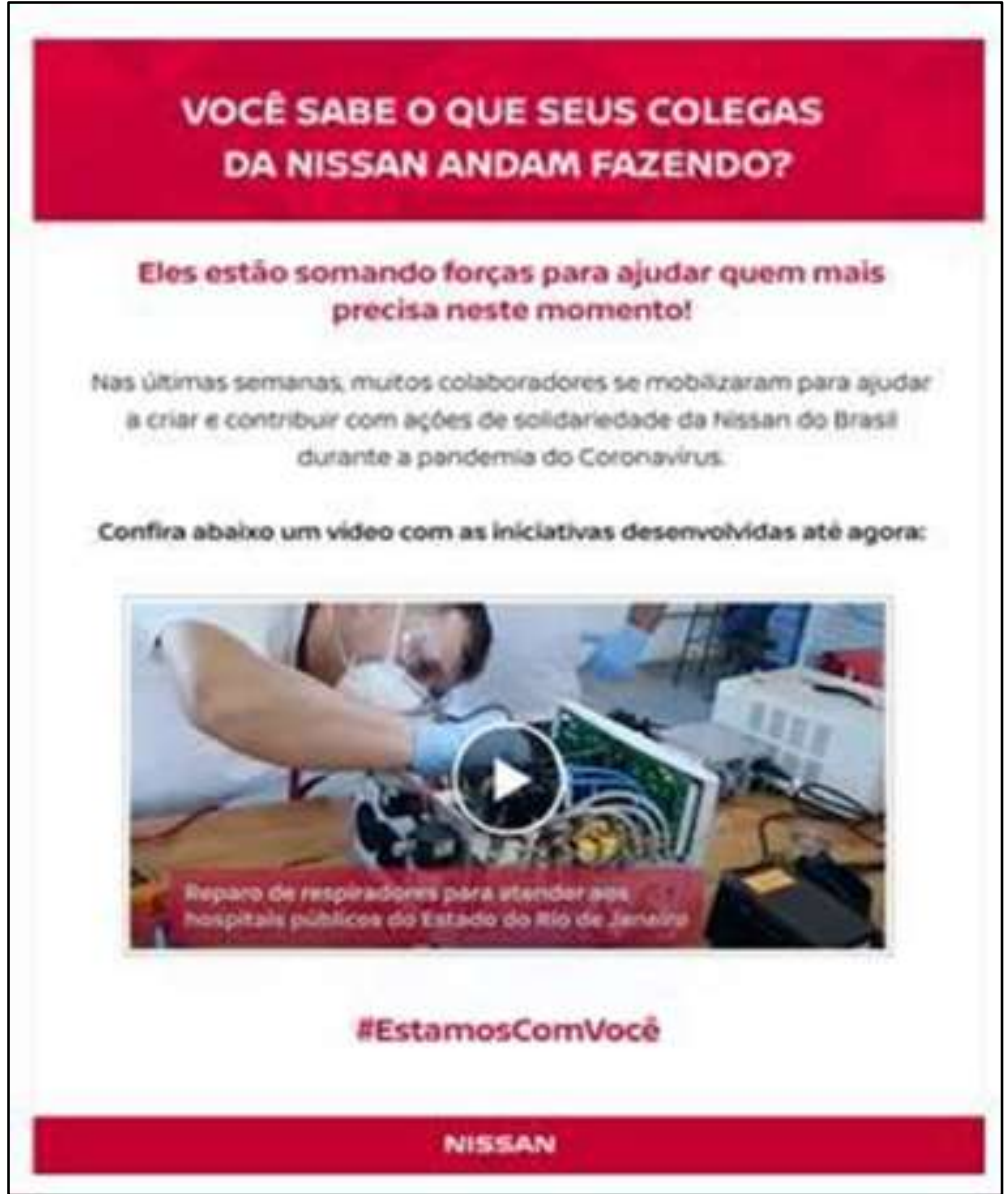

Fonte: Nissan Brasil, (2020).

A temática abordada na comunicação interna do dia 30 de abril de 2020 (Figura 18 e 19), versa sobre a flexibilização de rotinas do período agudo da pandemia e a utilização deste meio de comunicação (e-mail marketing) para fazer a aproximação de seus colaboradores. Mas uma vez se utiliza do dispositivo de vídeo para expor a ideia de solidariedade, observada anteriormente e a temática de 
aniversário da Fábrica de Resende, visa aproximação empresa-funcionário, incentivando os colaboradores e estimulando praticas coorporativas (Figura 19).

Figura- 19 Comunicação interna publicada em 30 de abril de 2020.

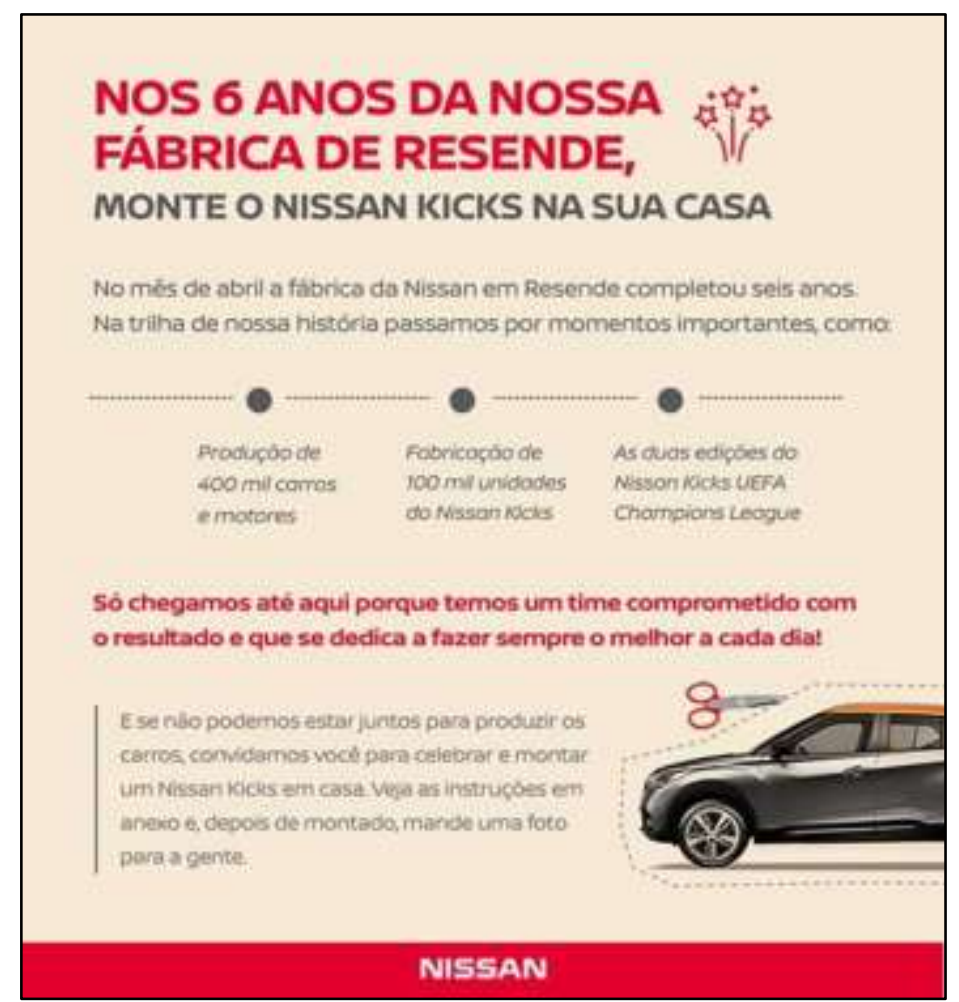

Fonte: Nissan Brasil, (2020).

O plano de expressão, segundo as categorias propostas por Teixeira (2008), e o aspecto textual apontam:

- Cromática: a predominância da cor vermelha, não há variação do tom na paleta de cores, estímulo visual;

- Eidética: uso de formas retas o que indica rigidez organizacional e formalidade;

- Topológica: proporcionalidade no layout, com a massa de texto bem distribuídas para ocupar a superfície da peça de comunicação interna, utilização de vídeo explicativo;

- Textual: a escrita é formal e hierárquica.

A comunicação interna do dia 07 de maio de 2020. (Figura 20) muda totalmente a temática e o layout. O tema aborda o dia das mães e a paleta de cores e linguagem empregada é branda e informal.

De acordo as categorias propostas por Teixeira (2008):

- Cromática: variedade dos tons pastéis na paleta de cores, estímulo visual; 
- Eidética: uso de formas retas na base, e linhas arredondadas o que indica rigidez organizacional combinada com informalidade;

- Topológica: proporcionalidade no layout, com a massa de texto bem distribuída para ocupar a superfície da peça de comunicação interna;

- Textual: a escrita é informal e ilustrativa.

Figura- 20 Comunicação interna publicada em 07 de maio de 2020.

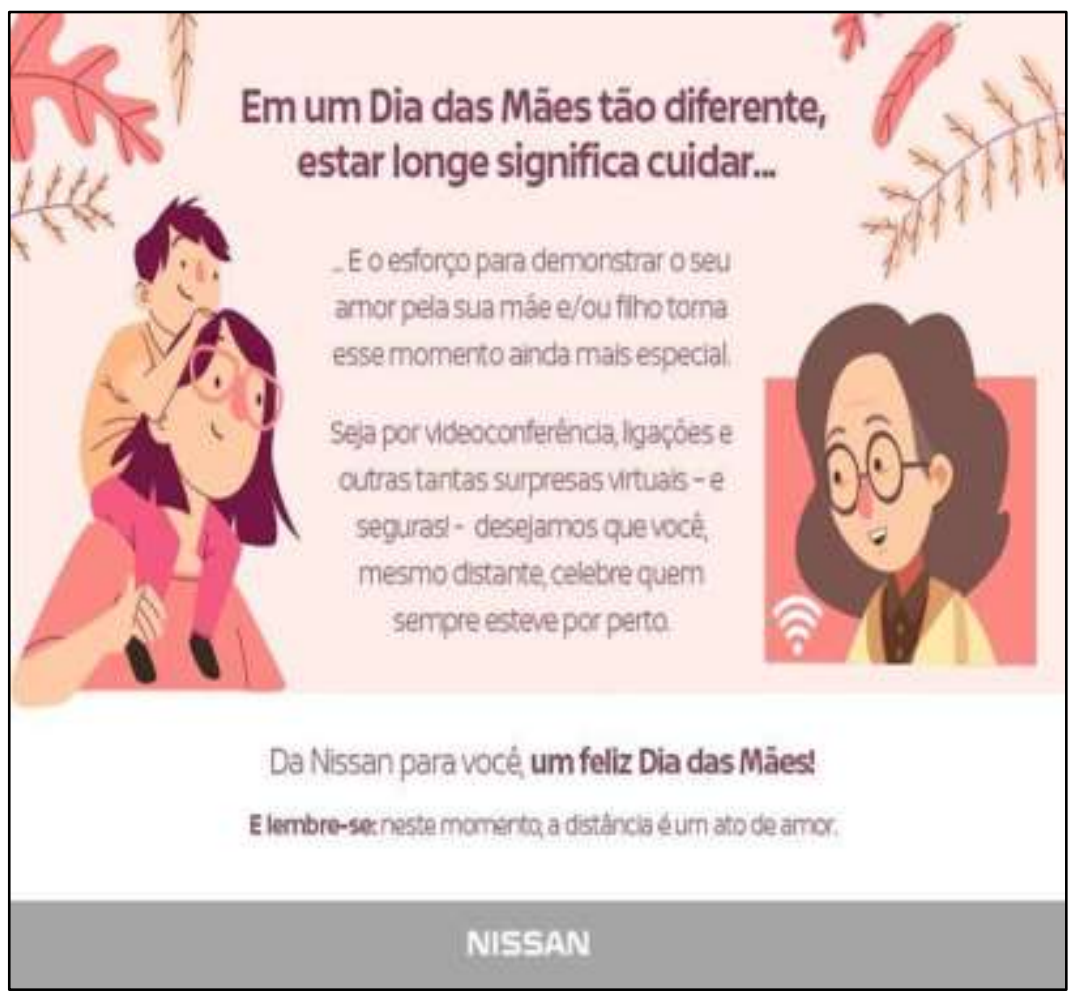

Fonte: Nissan Brasil, (2020).

A figurativização da peça, apelando para desenhos de mães com seus filhos, destaca a comunicação e pontua a data comemorativa.

A Figura 21 demonstra as diretrizes adotadas pela Nissan Brasil para o enfrentamento do COVID-19 em sua organização. Com a comunicação ilustrativa e explicativa, visa incorporar as regras de higiene na empresa.

Analisando a comunicação interna, observa-se:

- Cromática: variedade dos tons pastéis na paleta de cores azul (cor padrão hierárquica), estímulo visual;

- Eidética: uso de formas retas na base, e linhas arredondadas o que indica rigidez organizacional e informalidade;

- Topológica: proporcionalidade no layout, com texto bem definidos para ocupar a superfície da peça de comunicação interna, abordando de modo 
completo os pontos sobre a temática, de forma clara e transparente e ética com os seus colaboradores;

- Textual: a escrita é informal e ilustrativa.

Figura- 21 Comunicação interna publicada em 03 de junho de 2020.

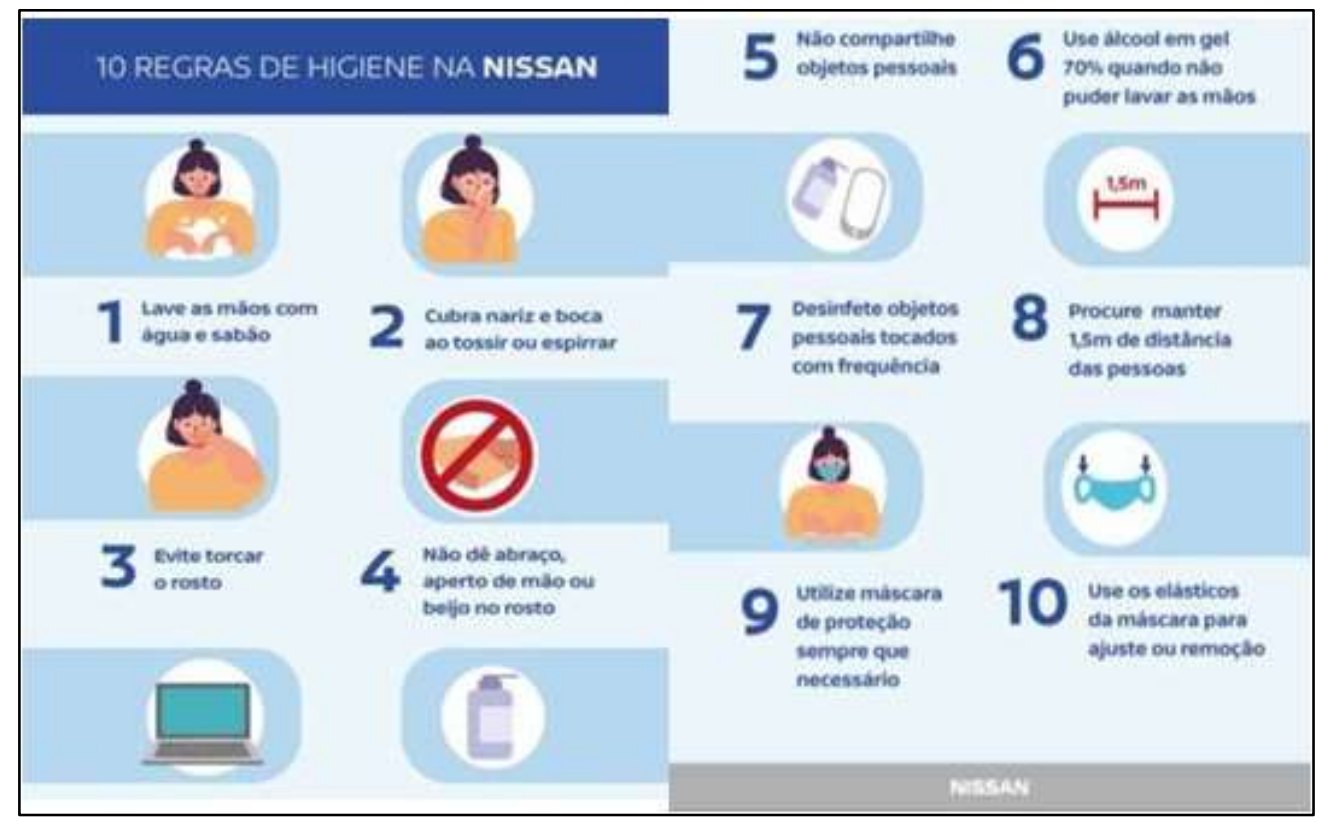

Fonte: Nissan Brasil, (2020).

A segunda ação é caracterizada pela intenção de conexão. Com a evolução do COVID-19, as distâncias geográficas foram ampliadas e em algumas peças de comunicação corporativa nota-se uma clara tentativa de reduzir essa lacuna espacial, gerando assim uma sensação de aproximação entre a organização e seus funcionários.

Ações do departamento de Recursos Humanos, promoveram de forma online, a interação entre os funcionários, com o objetivo de criar vínculos e reforçar os laços neste momento de afastamento social presencial.

Dentre as peças de comunicação interna publicadas nesse período, está a do dia 15 de junho de 2020 (Figura 22), que de forma explicita transmite a ideia de uma conexão ativa entre ambas as partes, mensagem empática, de forma leve que promove um espaço de confiança para colaboração de todos os funcionários. 
Figura- 22 Comunicação interna publicada em 15 de junho de 2020.

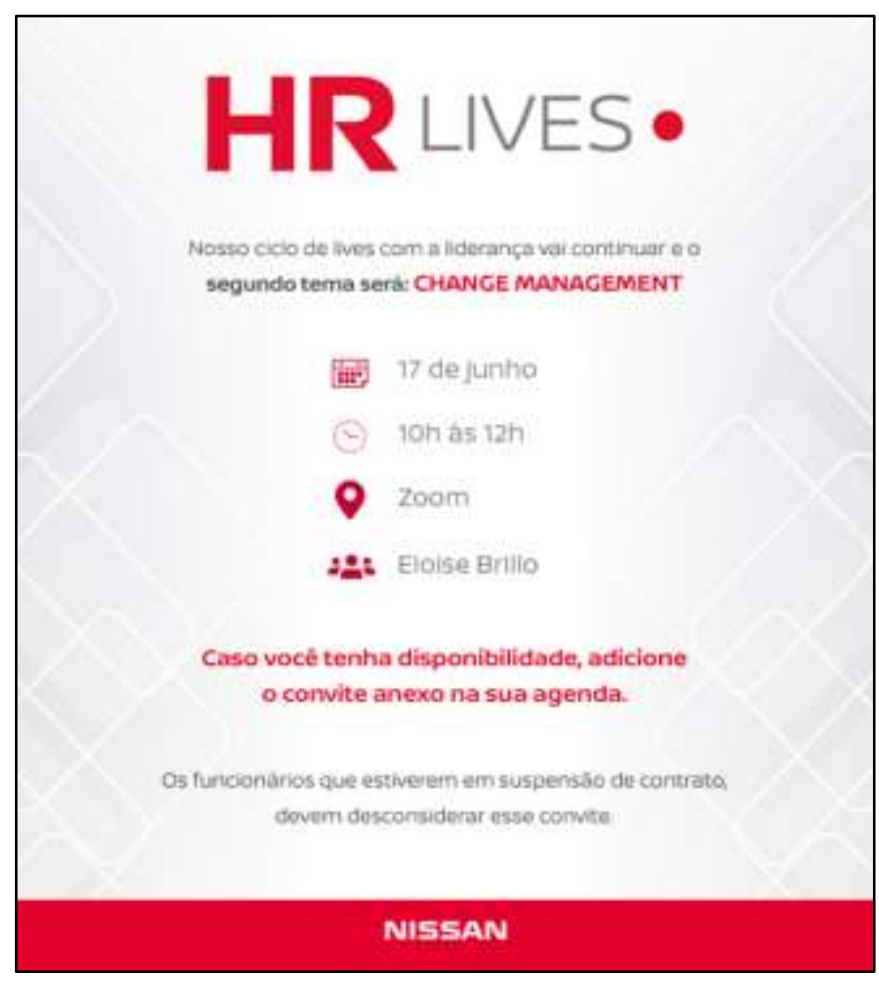

Fonte: Nissan Brasil, (2020).

Analisando a comunicação interna observa-se:

- Cromática: cor predominante vermelho (cor padrão hierárquica), estímulo visual;

- Eidética: uso de formas retas na base, e o que indica rigidez organizacional e formalidade;

- Topológica: proporcionalidade no layout, com texto bem definidos para ocupar a superfície da peça de comunicação interna;

- Textual: a escrita é formal e ilustrativa.

\subsection{Um novo começo: período de retomada corporativa na pandemia}

A última etapa trata o retorno para as atividades laborais de forma presencial, durante o período ativo da Pandemia, denominada como a fase de retomada.

Após três meses de reclusão social, suspensão contratual de $70 \%$ da força de trabalho e redução da jornada de trabalho para os $30 \%$ restantes, no final de junho a organização decidiu retomar as suas atividades presenciais. 
O dilema institucional era retornar para as fábricas e escritórios com total segurança, seguindo, assim, os padrões e normas estabelecidos pela OMS Organização Mundial da Saúde e Ministério da Saúde (BRASIL, 2020).

Para agir de forma eficiente, um comitê de "retorno" foi instaurado para que os executivos se sentissem responsáveis e atuantes nas tomadas de decisão.

Sendo assim, mais uma vez o plano de comunicação interna deveria refletir as decisões estrategicamente tomadas e de forma eficaz comunicar a mensagem a todos os colaboradores, deixando claro as práticas que deverão ser adotas e os passos de ação dessa retomada laboral.

Figura- 23 Comunicação interna publicada em 15 de junho de 2020.

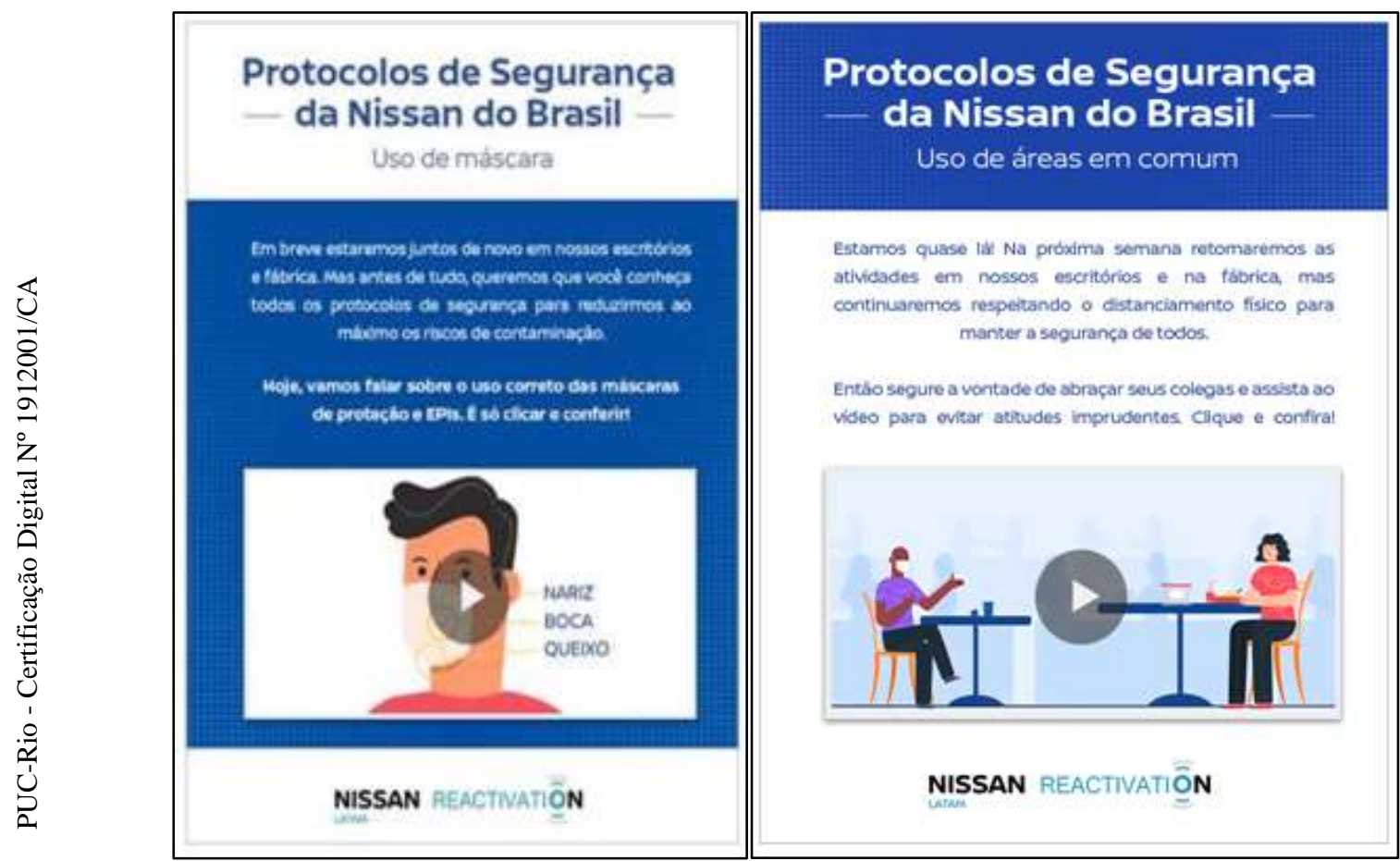

Fonte: Nissan Brasil, (2020).

Analisando as peças de e-mail marketing acima (Figura 23), pode-se notar um texto mais formal, composto por uma linguagem impessoal que demonstra hierarquia no título de chamada. Analisando a ilustração da arte, pode-se identificar uma linha visual global padronizada.

O padrão cabeçalho e rodapé volta a ser o mesmo da primeira fase analisada, independentemente da comunicação feita, seja ela positiva ou de grande atenção organizacional, como no caso acima.

O padrão mais "frio", traduzido pela cor azul e formalidade estrutural visualizada no cabeçalho e rodapé, faz parte da cultura organizacional de uma 
empresa de origem japonesa em que a estrutura rígida e a hierarquia são parte do "DNA" da Nissan.

Porém, a instituição de vídeo ilustrativo traz uma mudança de comportamento ainda que a peça esteja voltada para a formalidade.

O uso de linguagem informal ainda está presente com a utilização da frase “...então segure a vontade de abraçar seus colegas e assista ao vídeo...”.

A análise de acordo com as categorias propostas por Teixeira (2008):

- Cromática: emprego da cor azul (identidade visual da empresa). Há identificação de flexibilização de cores, dentro da mesma paleta cores;

- Eidética: uso de formas retas o que indica rigidez organizacional e formalidade;

- Topológica: proporcionalidade no layout, com a massa do texto bem distribuída para ocupar a superfície do elemento de comunicação interna, mais uma vez usando a escrita de modo objetivo e claro, apelo visual (vídeo);

- Textual: a escrita é formal e objetiva, reforçando os cuidados e como proceder em caso de dúvidas.

Observa-se este padrão nas peças de comunicação interna subsequentes no período analisado durante a retomada coorporativa das atividades da Nissan Brasil.

Segundo a empresa, a segurança e o bem-estar dos colaboradores é fundamental, pois, de acordo com os protocolos exigidos pelos serviços de saúde, são estabelecidas várias condições necessárias para garantir um ambiente de trabalho com o mais alto nível de segurança e prevenção no retorno da operação.

A empresa desenvolveu medidas de segurança e informação que seguem rígidos protocolos para garantir esse retorno. Todos os colaboradores têm à disposição uma ferramenta online que permitirá o autodiagnóstico antes de sair de casa.

A empresa afirma que se os funcionários estiverem em plena condição de saúde, deverão seguir as instruções para chegar ao trabalho com segurança. Para evitar aglomerações e garantir o distanciamento social, as aulas nos escritórios e nas fábricas foram organizadas em turnos. O trabalho remoto e o uso de várias plataformas virtuais estão mantidos. 
Embora ainda seja uma comunicação formal, utilizam-se meios subjetivos para orientar o destinatário, através de vídeos explicativos, e frases sugestivas de proximidade, visando estimular a percepção e o acolhimento funcional da organização.

Figura- 24 Comunicação interna publicada em 17 de junho de 2020.
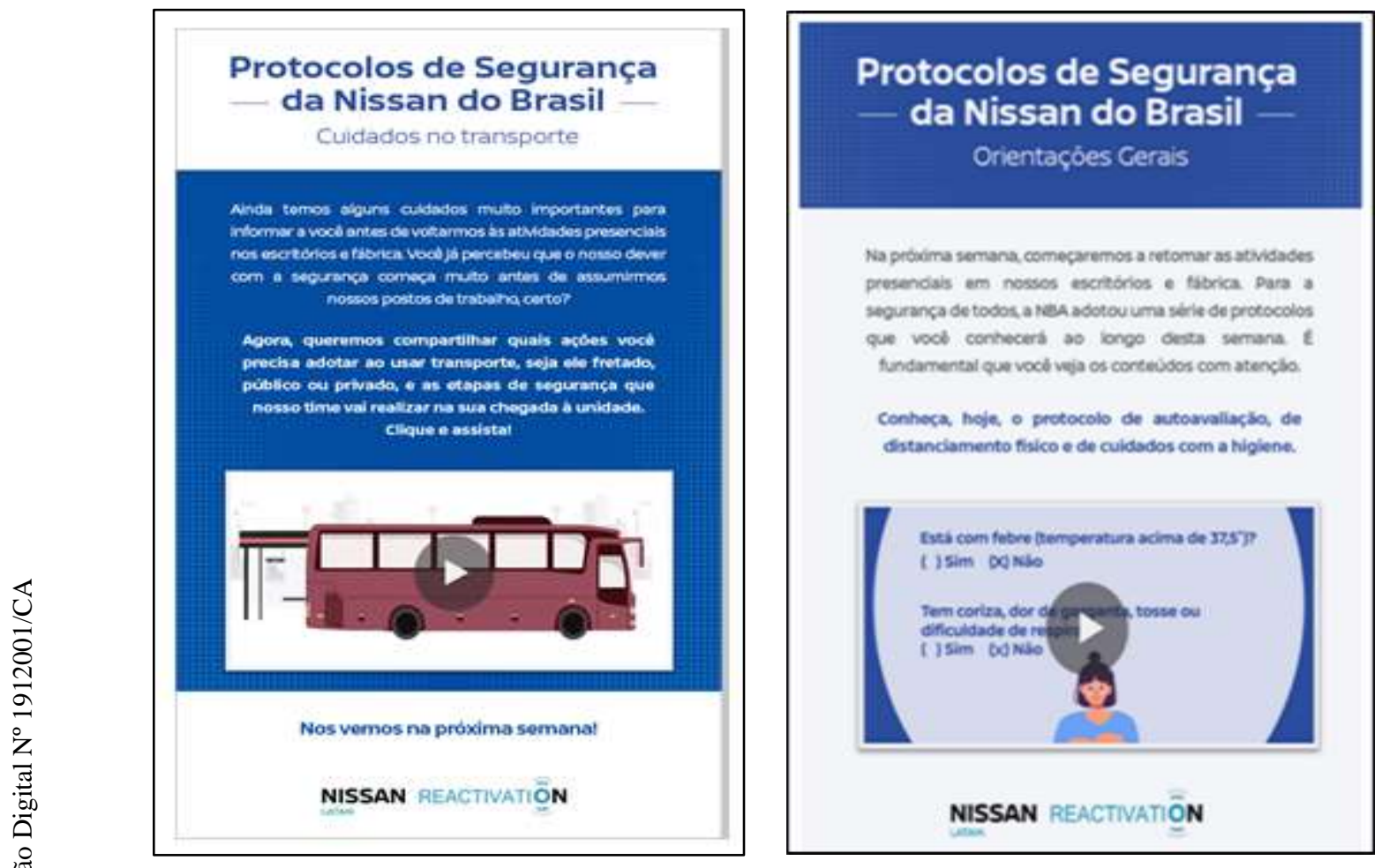

Fonte: Nissan Brasil, (2020).

A Figura 24 ilustra mais uma vez a abordagem clássica e formal, ainda voltada para os protocolos de segurança da empresa, com o emprego do padrão visual formal nas cores frias, com o mesmo estilo padrão de cabeçalho e título padrão, porém ao contrário das peças publicadas um dia antes (Figura 23), a linguagem utilizada nestas peças de comunicação interna é totalmente formal, sem ênfase na abordagem de comunicação informal. A narrativa muda, a estrutura organizacional do texto utiliza protocolo verbal, em que, por meio de palavras remetem ao senso de responsabilidade individual, ainda que coletivo.

De acordo com as categorias propostas por Teixeira (2008):

- Cromática: emprego da cor azul (identidade visual da empresa). Há identificação de flexibilização de cores, dentro da mesma paleta de tons;

- Eidética: uso de formas retas o que indica rigidez organizacional e formalidade; 
- Topológica: proporcionalidade no layout, com a massa do texto bem distribuída para ocupar a superfície do elemento de comunicação interna, mais uma vez usando a escrita de modo objetivo e claro, apelo visual (vídeo);

- Textual: a escrita é formal e objetiva, reforçando os cuidados e como proceder em caso de dúvidas.

A peça publicada em 03 de julho de 2020 (Figura 25), tende a ter um apelo informativo maior. Esse apelo se dá através da informação de monitoramento de casos na empresa, com informações claras e objetivas com caráter explicativo para seus funcionários.

Figura- 25 Comunicação interna publicada em 03 de julho de 2020.

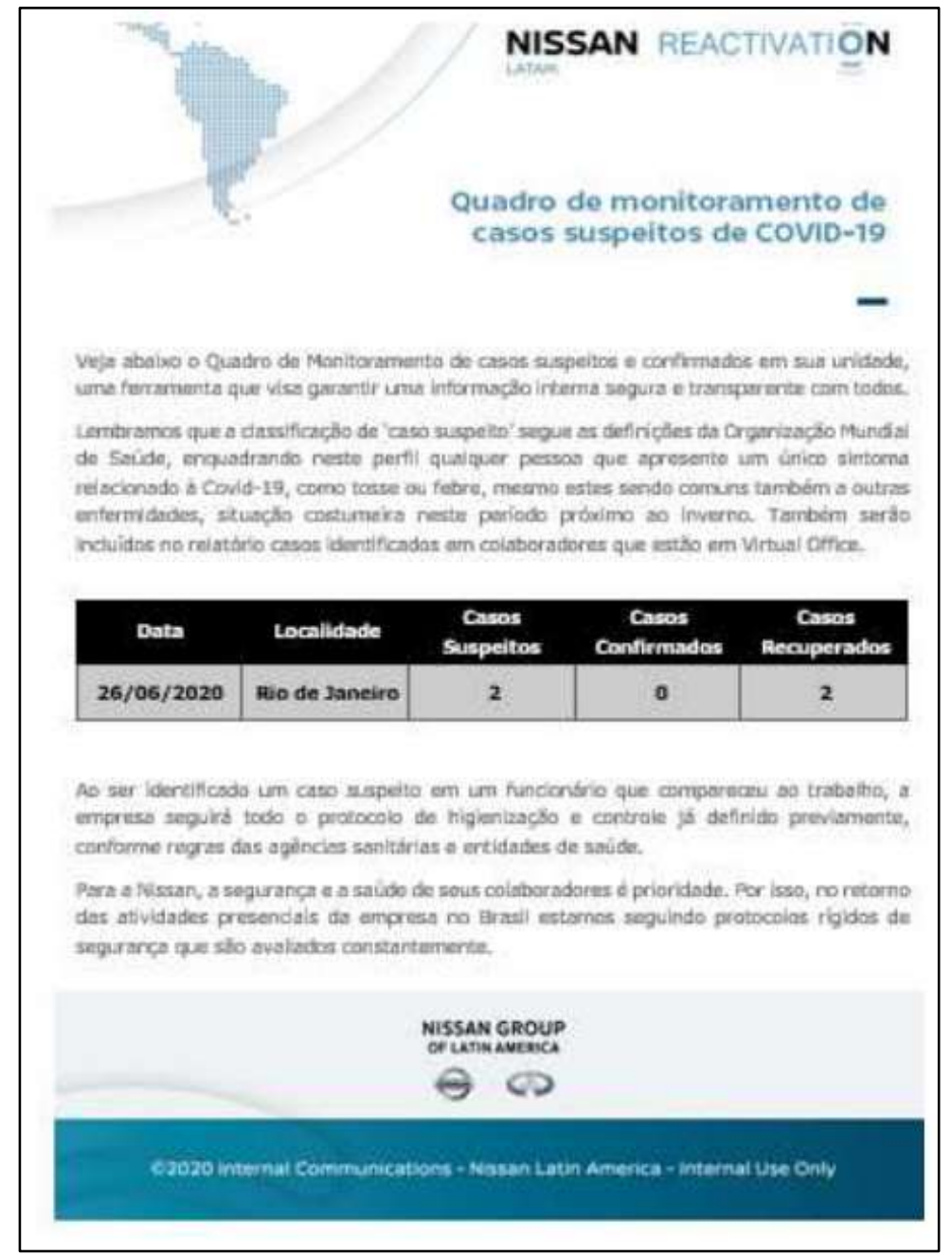

Fonte: Nissan Brasil, (2020).

Nota-se a mudança de padrão de cores na comunicação interna hierárquica, mas a rigidez de linguagem e denotação formal são utilizadas. 
A ánálise da Figura 25 consiste em:

- Cromática: emprego da cor azul (identidade visual da empresa). Há identificação de flexibilização de cores, dentro da mesma paleta de tons e a utilização do tom preto;

- Eidética: uso de formas retas o que indica rigidez organizacional e formalidade;

- Topológica: proporcionalidade no layout, com a massa do texto bem distribuída para ocupar a superfície do elemento de comunicação interna, apelo visual (ilustrações e gráficos);

- Textual: a escrita é formal e objetiva, com clareza e objetividade.

A última comunicação interna a ser analisada nesta pesquisa reforça os cuidados em áreas comuns da organização. Novamente o padrão de cores muda e a linguagem se torna mais explicativa e figurativa (Figura 26).

Figura- 26 Comunicação interna publicada em 03 de julho de 2020.

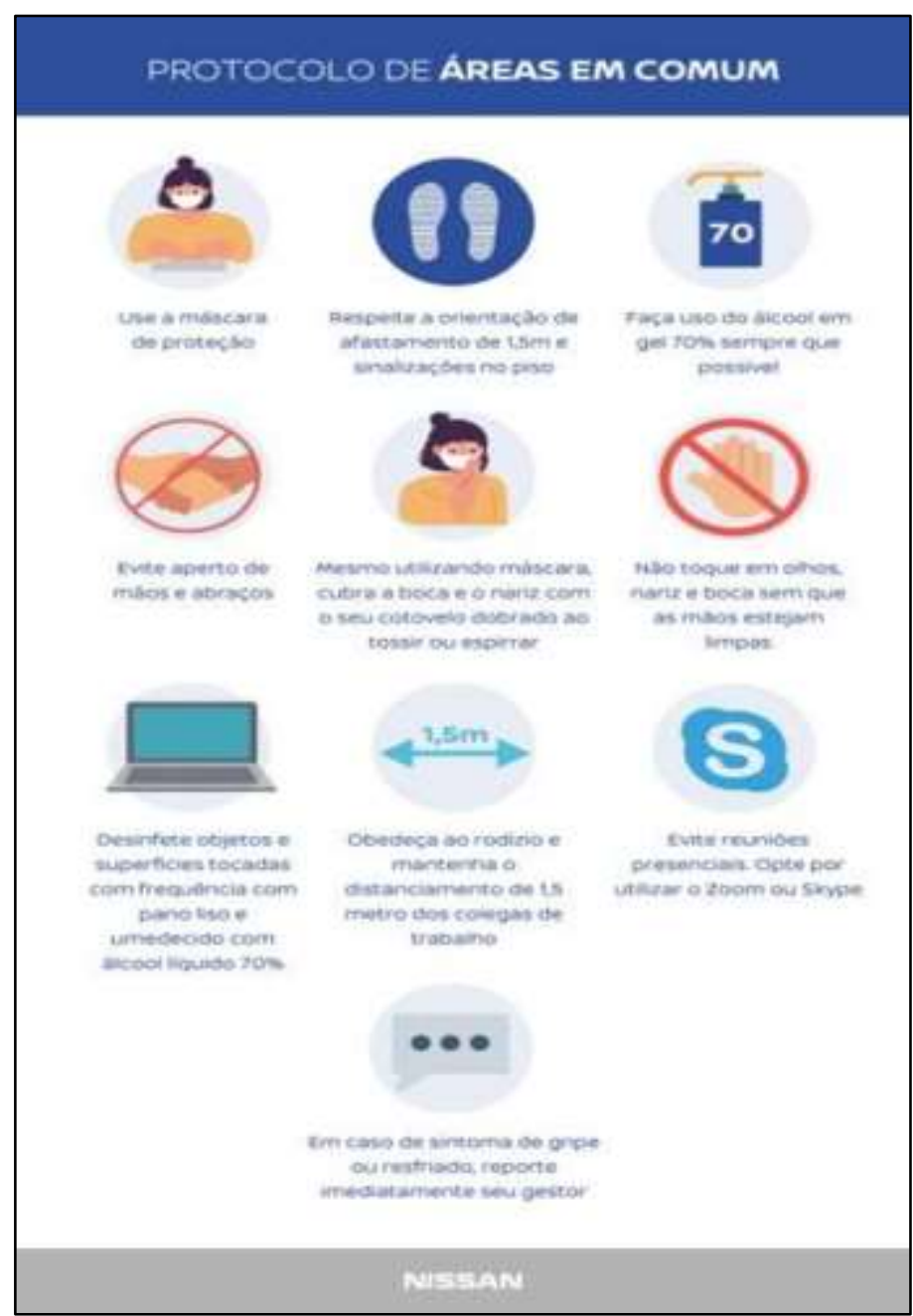

Fonte: Nissan Brasil, (2020). 
Seguindo a análise proposta por Teixeira, (2008):

- Cromática: a predominância da cor azul, variedade dos tons na paleta de cores, estímulo visual;

- Eidética: uso de formas retas na base, e linhas arredondadas o que indica rigidez organizacional e informalidade;

- Topológica: proporcionalidade no layout, com a massa de texto bem distribuídas para ocupar a superfície da peça de comunicação interna, abordando de modo completo os pontos sobre a temática, de forma clara e transparente e ética com os seus colaboradores;

- Textual: a escrita é informal e ilustrativa.

\subsection{Síntese da análise}

Diante de uma complexidade emergencial como a pandemia de COVID-19, a narrativa organizacional da Nissan Brasil tende a oscilar entre a linguagem formal e informal e a utilizar vários recursos expressivos, visando fazer entender seus valores e objetivos enquanto organização, conforme demonstrado na análise realizada.

As organizações constroem comunicações e narrativas de integridade com base em sua cultura organizacional, valores e identidade. As narrativas, além de buscarem a sintonia com seus públicos, também buscam ganhar legitimidade, pois é iminente a necessidade de uma contínua justificação social por parte das organizações.

Tendo em vista a análise semiótica francesa das peças de comunicação interna apresentadas no presente trabalho, entende-se que a comunicação organizacional é muito importante para a abordagem informacional clara e objetiva, quando traçada de forma eficiente.

O quadro a seguir procura sintetizar as análises realizadas. 
Tabela 3- Síntese da análise.

\begin{tabular}{|c|c|c|c|}
\hline & $\begin{array}{l}\text { Período de Pré- } \\
\text { Pandemia: } \\
\text { Quebrando a } \\
\text { formalidade }\end{array}$ & $\begin{array}{c}\text { Período agudo } \\
\text { da Pandemia: } \\
\text { Construindo } \\
\text { Conexões }\end{array}$ & $\begin{array}{c}\text { Período de } \\
\text { retomada } \\
\text { corporativa: } \\
\text { Um novo começo }\end{array}$ \\
\hline CROMÁTICA & $\begin{array}{l}\text { Predominância da cor } \\
\text { vermelha (identidade } \\
\text { visual da empresa). } \\
\text { Alinhamento com o } \\
\text { padrão e diretrizes } \\
\text { global. }\end{array}$ & $\begin{array}{l}\text { Sinais } r \\
\text { flexibilização da } \\
\text { paleta de cores. } \\
\text { Ainda que dentro da } \\
\text { tonalidade } \\
\text { institucional do azul e } \\
\text { vermelho. }\end{array}$ & \multirow{4}{*}{$\begin{array}{l}\text { Nota-se alternância } \\
\text { de padrões em todos } \\
\text { os critérios. } \\
\text { As peças da temática } \\
\text { COVID-19 ainda } \\
\text { permanecem com a } \\
\text { diversificação de } \\
\text { tonalidade, } \\
\text { diagramação flexível, } \\
\text { como o analisado na } \\
\text { da fase } 2 \text {. } \\
\text { Porém, os novos } \\
\text { anúncios } \\
\text { organizacionais de } \\
\text { temática geral como: } \\
\text { Mudanças estruturais, } \\
\text { Informação sobre } \\
\text { jornadas de trabalho, } \\
\text { informativos globais } \\
\text { entre outros já } \\
\text { retornam ao padrão } \\
\text { da fase } 1 \text { com cores e } \\
\text { estruturas mais } \\
\text { rígidas. }\end{array}$} \\
\hline EIDÉTICA & $\begin{array}{l}\text { Uso de formas retas } \\
\text { (tanto na diagramação } \\
\text { exemplificado pelo } \\
\text { cabeçalho e rodapé, } \\
\text { quanto nos ícones), o } \\
\text { que traduz rigidez e } \\
\text { formalidade. }\end{array}$ & 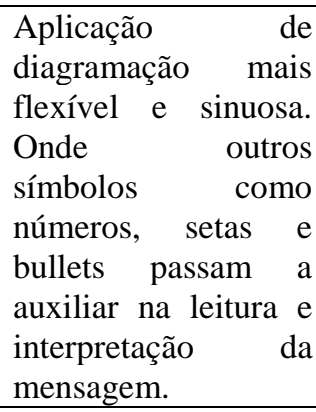 & \\
\hline TOPOLÓGICA & $\begin{array}{l}\text { Proporcionalidade nos } \\
\text { layouts, massa de texto } \\
\mathrm{e} \text { as imagens bem } \\
\text { distribuídas para ocupar } \\
\text { a superfície das peças de } \\
\text { comunicação interna. } \\
\text { O preenchimento de } \\
\text { todas as lacunas do } \\
\text { texto conecta com o } \\
\text { valor corporativo de } \\
\text { "transparência" da da d } \\
\text { organização e ética com } \\
\text { os seus colaboradores. }\end{array}$ & $\begin{array}{lr}\text { Proporção } \\
\text { rígida. menos } \\
\text { A diagramação } \\
\text { textual é modificada, } \\
\text { tornando-se } & \text { mais } \\
\text { flexível e com a nova } \\
\text { formatação de raços } \\
\text { mais lúdicos, o texto } \\
\text { passa a } & \text { ser } \\
\text { secundário. } & \text { A } \\
\text { preocupação } & \text { com } \\
\text { transparência "cede" } \\
\text { espaço para a } \\
\text { preocupação } \\
\text { "empatia", de } \\
\text { imagens buscam uma } \\
\text { aproximação com } \\
\text { colaborador. }\end{array}$ & \\
\hline TEXTUAL & $\begin{array}{l}\text { Na maior parte das } \\
\text { publicações dessa fase, } \\
\text { nota-se que a escrita é } \\
\text { formal e hierárquica. } \\
\text { Demonstrando robustez } \\
\text { organizacional } \\
\text { transparecendo } \\
\text { distanciamento entre as } \\
\text { funções, } \\
\text { evidenciado pelos } \\
\text { cargos. }\end{array}$ & $\begin{array}{l}\text { Texto sem estrutura } \\
\text { organizacional rígida } \\
\text { ou hierárquica, } \\
\text { citações rão } \\
\text { realizadas em terceira } \\
\text { pessoa do plural } \\
\text { "Nós": "Nós não } \\
\text { podemos sair" } \\
\text { A linguagem é mais } \\
\text { Coloquial e Informal } \\
\text { com expressões } \\
\text { populares como: } \\
\text { "Keep Calm and.." e } \\
\text { "Sextou". }\end{array}$ & \\
\hline
\end{tabular}

Fonte: autoria própria, (2020). 
As operações fabris foram retomadas, presencialmente, em junho de 2020 e as operações de formato administrativo permanecem em home office.

Dentre as medidas implementadas destaca-se o home office como sendo a de maior reflexo da flexibilização forçada desse período pandêmico. Flexibilização essa que foi avaliada nesta dissertação através da mudança da narrativa organizacional, de um modelo formal para um modelo mais informal, durante o recorte de janeiro a Agosto de 2020, onde teve o início e o período agudo da pandemia.

A flexibilização exposta nas comunicações internas se deu através de:

- Aplicação de linguagem figurativa lúdica;

- Diversificação da paleta de cores, ainda que nos tons da identidade corporativa;

- Aplicação de expressões de informalidade nos textos;

Culminou, de fato, em mudanças organizacionais nas ações da Nissan Brasil:

- Implementação da estrutura de home office permanente para a área administrativa;

- Implementação de um ciclo de jornada reduzida com "Flex Friday";

- Implementação do "Day off no aniversário";

- Adequação das políticas de delegação de autoridade com mais flexibilidade de cargos;

- Reconhecimento da assinatura virtual em documentos oficiais da organização;

- Implementação das lives do RH, na ferramenta virtual de Zoom, com o objetivo de promover discussões de grupos e estimular o contato entre as pessoas, ainda que afastadas geograficamente.

O home office permanente para a área administrativa dentre as ações listadas acima, mostra a maior flexibilização. A Nissan Brasil como já citado é uma organização japonesa, sendo assim fundamentada numa cultura hierárquica e rígida em padrões de controle. Ao implementar a jornada corporativa no formato virtual, a organização sinaliza um grande passo de adaptação ao novo cenário e de tentativa de se enquadrar num novo contexto global. 


\section{Considerações finais}

De uma forma geral, Eco (1991) afirma que a semiótica da comunicação vai além dos bucólicos atos comunicativos; chega aos sintomas incitados pelas sensações e abrange até mesmo o inconsciente do emissor e do receptor, passando por fatores culturais que intervêm neste processo.

Por meio desta dissertação, que parte do pressuposto da importância da comunicação interna na estratégia das organizações, pretendeu-se colaborar com a comunicação interna da Nissan Brasil no período de pandemia, tendo como base o uso de ferramentas da semiótica francesa.

Para tal, foram estabelecidas as seguintes perguntas de pesquisa: quais foram as mudanças na comunicação para o público interno da empresa Nissan Brasil durante o período inicial de Pandemia? Como estas mudanças contribuíram para a implementação de ações organizacionais de flexibilização das rotinas organizacionais?

O corpus de pesquisa foi composto por 26 peças de comunicação interna da Nissan Brasil analisadas sob a ótica da semiótica francesa (GREIMAS, 1976).

A pandemia do COVID-19 de fato influenciou a Nissan Brasil para que houvesse uma mudança de narrativa organizacional durante este período e isso pode ser analisado nas três fases descritas: período pré-pandemia, período agudo da pandemia e período de retomada coorporativa na pandemia.

A primeira fase foi marcada por uma estrutura rígida, hierárquica, onde se observou que a comunicação interna da Nissan Brasil sempre teve como foco o direcionamento informativo, reportando mudanças organizacionais, jornada de trabalho, carga horária diária, regras de conduta corporativa, direcionamento estratégico e visão de planejamento de alto nível, com padrões gráficos frios ou formal.

Já durante a segunda análise da fase aguda da pandemia, a comunicação interna da empresa apresentou indícios de flexibilização que foram notórios através de uso de figuras de linguagem com uso de expressões informais, alteração no padrão de cor apresentada e o maior uso de figuras e símbolos visando promover a integração da equipe.

A terceira e última análise da fase de retomada de atividades coorporativas, apresentou novamente o padrão identitário da empresa, porém nota-se o uso de 
vídeos explicativos e a atenção na narrativa explicativa onde a clareza e objetividade das informações tendem a ser maior.

Como reflexo dessa flexibilização, a organização precisou revisitar os seus processos organizacionais e reestruturar um fluxo que fizesse sentido e comportasse a configuração deste momento.

Implementando novas rotinas organizacionais como a flexibilização das rotinas de trabalho, flexibilização dos processos de aprovação e delegação de autoridade para tomada de decisão, a implantação do home office, a mudança significativa na esfera da comunicação interna que passou a ter uma linguagem mais informal e visual, adoção de novos canais como WhatsApp, site da organização e reforço do $e$-mail corporativo, além da certificação de que a linguagem aplicada, se adequa aos novos desafios.

O home office se tornou permanente para a parte administrativa da empresa no Brasil, a estrutura de tecnologia da informação foi ajustada para suportar o trabalho remoto dos mais de 2 mil funcionários.

Workshops e seminários saíram das estruturas de hotéis para plataformas online como o Zoom e processos burocráticos de assinaturas e aprovações sofreram ajustes de delegação de autoridade.

Pode-se concluir que a comunicação interna adaptada na segunda fase descrita na dissertação criou um contexto de maior "informalidade" gerencial no âmbito dessa organização, o que colaborou para a flexibilização de alguns processos organizacionais.

Com isso, o desenvolvimento efetivo de um plano integrado de comunicação, possibilitou grandes benefícios e vantagens, entre os quais se destacam: a contribuição para a manutenção de um clima positivo, propício à concretização dos objetivos estratégicos da organização, o crescimento contínuo das suas atividades, e extensão das suas linhas de serviço, gerando motivação e integração do corpo funcional na cadeia de mudanças organizacionais, estabelecendo mecanismos e ferramentas de informação, persuasão e compromisso, e por fim criando uma realidade de mudança climática, sensibilizando a organização para as mudanças.

A comunicação interna da Nissan Brasil, cumpriu seu objetivo em esclarecer e motivar seus colaboradores de forma sutil e atingiu a meta de manter seus funcionários informados, fazendo o uso de variação de padrão da linguagem aplicada. 
Destaca-se ainda que futuras pesquisas podem retomar essa pesquisa dando continuidade à análise do período pós pandêmico, verificando se de fato houve contribuição nas práticas corporativas. 


\section{Referências Bibliográficas}

ALVESSON, M.; KARREMAN, D. Varieties of discourse: on the study of organizations through discourse analysis. Human relations, New York, v. 53, n. 9, p. 1125-1149, Sep. 2000.

BARDIN, L. Análise de Conteúdo. São Paulo: Edições 70, 2011.

BARROS, D. L. P. Teoria do discurso: fundamentos semióticos. 3. ed. São Paulo: Humanitas/FFLCH/USP, 2001.

BARROS, D. L. P. Estudos do discurso. In: FIORIN, J. L. (Org.). Introdução à Linguística II - Princípios de análise, p. 187 - 219. São Paulo: Contexto, 2005.

BARROS, D. L. P. Publicidade e figurativização. ALFA: Revista de Linguística, v. 47, n. 2, p. 11-31, 2004.

BERTRAND, D. Caminhos da semiótica literária. Trad. de Ivã Lopes e Grupo Casa. Bauru: EDUSC, 2003.

BORBA, F.S. Introdução aos Estudos Linguísticos. Campinas, SP: Pontes, 14ㄹ. . ed., 2005.

BRASIL, LEI n. 13.979, de 6 de fevereiro de 2020. Diário Oficial da União, Brasília, DF, 2020. Disponível em: http://www.planalto.gov.br/ccivil 03/ ato2019-2022/2020/lei/l13979.htm . Acesso em: 26 nov. 2020.

BRASIL, Ministério da Saúde. Infecção Humana pelo Novo Coronavirus (2019-nCoV). Boletim Epidemiológico. 2020. Disponível em: https://portalarquivos2.saude.gov.br/images/pdf/2020/fevereiro/13/Boletimepidemiologico-COEcorona-SVS-13fev20.pdf . Acesso em: 05 nov. 2020.

BRASIL. Medida Provisória n.9 927, de 22 de março de 2020. Diário Oficial da União, Brasília, DF, 2020. Disponível em: http://www.planalto.gov.br/ccivil 03/ ato2019-

2022/2020/Mpv/mpv927.htm. Acesso em: 25 nov. 2020.

BRASIL. Medida Provisória n. 936, de $1^{\circ}$ de abril de 2020. Diário Oficial da União, Brasília, DF, 1ำ abr. 2020a. Disponível em: http://www.planalto.gov.br/ccivil 03/ ato2019-

2022/2020/mpv/mpv936.htm. Acesso em: 25 nov. 2020.

BRASIL. Ministério da Saúde. Medidas para retomada de atividades. 2020. Disponível em: https://www.gov.br/saude/ptbr\#: : :text=A\%20medida\%20refor\%C3\%A7a\%20e\%20detalha,a\%20sere m\%20adotadas\%20individualmente\%20e . Acesso em: 04 out. 2020.

BUENO, W. C. da. A comunicação empresarial estratégica: definindo os contornos de um conceito. Conexão - Comunicação e Cultura, UCS, Caxias do Sul, v. 4, n. 7, p. 11-20, jan./jun. 2005. 
CONASS. Conselho Nacional de Secretários de Saúde. Guia Orientador para o enfrentamento da pandemia Covid-19 na Rede de Atenção à Saúde. Brasília, DF, mai. 2020.

CORTINA, A.; MARCHEZAN, R. C. Teoria semiótica: a questão do sentido. In: MUSSALIN, F.; BENTES, A. C. (Org.). In: Introdução à linguística: fundamentos epistemológicos, v. 3. São Paulo: Cortez, 2004.

DELLAGNELLO, E. H. L.; SILVA, R. C. Análise de Conteúdo e sua aplicação em pesquisa na Administração. In: VIEIRA, M.M.F.; ZOUAIN, D.M. (org.). Pesquisa Qualitativa em Administração. Rio de Janeiro: Editora FGV, 2005.

DOMANESCHI, E. O quadrado semiótico greimasiano: herança e transformação. In: Estudos semióticos, n especial p. 51-58, nov. 2017. Disponível em: www.revistas.usp.br/esse . Acesso em: 22 set. 2020.

ECO, U. Tratado geral de semiótica. $2^{\underline{a}}$ ed. São Paulo: Perspectiva. 1991.

ECO, U. Tratado geral de semiótica. 5a ${ }^{a}$. ed. São Paulo: Perspectiva, 282 p. (Estudos). 2014.

FIORIN, J. L. Linguagem e ideologia. São Paulo: Ática, 1988.

FIORIN, J. L. Semiótica das paixões: o ressentimento. Alfa, São Paulo, n. 51, p. 9-22, 2004.

FONTANILLE, J. Semiótica do discurso. Trad. Jean Cristtus Portela. São Paulo: Contexto, 2007.

FONTANILLE, J. \& ZILBERBERG, C. Tensão e significação. Trad. Ivã Lopes, Luis Tatit e Waldir Beividas. São Paulo: Humanitas, 2001.

GREIMAS, A. J. Sobre o sentido: ensaios semióticos. Trad. Ana Cristina Cruz Cezar et al. Petrópolis: Vozes, 1975.

GREIMAS, A. J. Semântica estrutural. Pesquisa de Método. Trad. Haquira Osakabe e Izidoro Blikstein. São Paulo: Cultrix/EDUSP, 1976.

GREIMAS, A. J.; COURTÉS, J. Dicionário de semiótica. Trad. Alceu Dias Lima et al. São Paulo: Cultrix. 1983.

GREIMAS, A. J. \& FONTANILLE, J. Semiótica das paixões. Dos estados de coisas aos estados de alma. Trad. Maria José R. Coracini. São Paulo: Ática, 1993.

GREIMAS, A. J.; COURTÉS, J. Dicionário de Semiótica. 7. ed. São Paulo: Contexto, 2008.

HOUAISS, A. Dicionário Houaiss da Língua Portuguesa. 1. ed. São Paulo: Editora Objetiva. 2001. 
HJELMSLEV, L. Prolegômenos a uma teoria da linguagem. São Paulo: Perspectiva, 1975.

IQG- HEALTH SERVICES ACCREDITATION. Boas práticas de comunicação durante a pandemia. [site de internet]. 2020. Disponível em: $\quad$ https://www.igg.com.br/2020/04/13/boas-praticas-de-comunicacaodurante-a-pandemia/ . Acesso em: 23 nov. 2020.

KNUSCH, M. M. K. (org.). Comunicação organizacional: histórico, fundamentos e processos. V. 1. São Paulo: Saraiva, 2009.

KOTLER, P.; ARMSTRONG, G. Princípios de Marketing. 9. ed. São Paulo: Prentice Hall, 2003.

LUPETTI, M. Gestão estratégica da comunicação mercadológica. São Paulo: Thompson Learning, 2007.

MENAN, M. A importância da comunicação interna nas organizações. 2018. Disponível em : https://www.inesul.edu.br/revista/arquivos/arqidvol 9 1287601209.pdf . Acesso em: 02 nov. 2020.

MODRO, M. V. A prática literária e a análise discursiva no processo de ensino/aprendizagem de línguas. In: CELLI - COLÓQUIO DE ESTUDOS LINGUÍSTICOS E LITERÁRIOS. 3, 2007, Maringá. Anais... Maringá, p. 664-672. 2009.

NISSAN. O novo modelo Versa Nissan. [site de internet]. 2020. Disponível em: https://www.nissan.com.br/veiculos/modelos/novoversa.html . Acesso em: 29 nov. 2020.

NISSAN MOTORS DO BRASIL. Nissan comemora 20 anos de uma história de sucesso no Brasil. Rio de Janeiro, RJ. [site de internet] 2020. Disponível em: https://brazil.nissannews.com/pt-BR/releases/releasee1f616019d7ee426949edb5b6d274a07-nissan-comemora-20-anos-deuma-historia-de-sucesso-no-brasil Acesso em: 26 nov. 2020.

NISSAN MOTORS CORPORATION. Outline of Company. [site de internet]. 2020. Disponível em: https://www.nissanglobal.com/EN/COMPANY/PROFILE/HERITAGE/HISTORY/ . Acesso em: 29 nov. 2020.

OIT, Organização Internacional de Trabalho. Como a COVID-19 afetará o mundo do trabalho? [site de internet], 2020. Disponível em: https://www.ilo.org/brasilia/noticias/WCMS 740753/lang--pt/index.htm . Acesso em: 26 nov. 2020.

OPAS. Organização Pan Americana de Saúde. Folha informativa COVID19 Escritório da OPAS e da OMS no Brasil. Brasil. 2020. Disponível em: https://www.paho.org/pt/covid19 . Acesso em: 04 out. 2020.

PESSÔA, L. A. G. P. Narrativas da segurança no discurso publicitário: um estudo semiótico. São Paulo: Editora Mackenzie, 2013. 
SFEZ, L. Crítica da comunicação. São Paulo: Loyola, 2000.

SILVA, F. M. Avanços da Semiótica Francesa: Estudos na Comunicação. In: Intercom, Sociedade Brasileira de Estudos Interdisciplinares da Comunicação. XII Congresso de Ciências da Comunicação na Região Sul, Londrina, PR. 26 a 28 de maio de 2011. Disponível em: http://www.intercom.org.br/papers/regionais/sul2011/resumos/R25-0270-

1.pdf Acesso em: 19 ago. 2020.

STARTSE. 56\% das empresas estão lutando para sobreviver [artigo de internet]. 2020. Disponível em: https://www.linkedin.com/pulse/56-dasempresasest\%C3\%A3olutandoparasobreviverjuniorborneli/?articleld=6653 737506430820353 . Acesso em: 26 nov. 2020.

SU, S.; WONG, G.; SHI, W. et al. Epidemiology, genetic recombination, and pathogenesis of coronaviruses. In: Trends Microbiol. ed. 24, p. 490-502, 2016.

TAVARES, M. Comunicação Empresarial e Planos de Comunicação. São Paulo: Editora Atlas S.A, 2010.

TEIXEIRA, L. Argumentação e semiótica. In: Congresso Internacional da ABRALIN, Fortaleza, março 2008. Disponível em: https://www5.pucsp.br/cps/downloads/biblioteca/2016/teixeira I argume nta ao e semiotica .pdf. Acesso em: 30 nov. 2020.

VALENTIM, M. L. P. Inteligência competitiva em organizações: dado, informação e conhecimento. Data Grama Zero, Rio de Janeiro, v.3, n.4, ago. 2002. Disponível em: https://brapci.inf.br/index.php/res/v/3837 . Acesso em: 14 out. 2020.

VASCONCELOS, P. S.; VASCONCELOS, P. E. A. Desafios da Estratégia Empresarial: antes, durante e após a pandemia de 2020. In: Revista Interdisciplinar de Direito. v. 18, n. 1, pp 163-182, jan./jun. 2020. Disponível em: https://core.ac.uk/download/pdf/328015675.pdf . Acesso em: 27 nov. 2020.

WELLE, A. et al. Impactos da MP 936/2020 no rendimento dos trabalhadores e na massa salarial. Campinas: Cecon, n.․ 11, 2020. Disponível em: https://www.economia.unicamp.br/images/arquivos/notado-cecon-MP936-F2.pdf. Acesso em: 20 dez. 2020.

WOODRUFF, P. W. R.; BENSON, R. R.; BANDETTINI, P. A.; Modulation of auditory and visual cortex by selective attention is modalitydependent. Neuroreport, $7^{\mathrm{a}}$ ed, p. 1909-1913, 1996. 


\section{Anexo I Comunicações internas da pesquisa}

Anexo 1: Comunicação interna publicada em 23/01/2020.

\section{NISSAN VOICE ON \\ BRASIL.}

Anúncio Organizacional NBA

Enviado em nome de

- presidente da Nissan do Brasil, e

vice-presidente de A8F da Nissan LATAM.

Efetivo em 1 de Marco,

- atualmente diretor de Financas de

Monozukuri da Nissan Mexicana, serb nomeado CFo da Nissan do Brasil. Armando é bacharel em Administraç5o Financeira e tem MBA em Marketing pelo Instituto Tecnolbgico

de Estudios Superiores de Monterrey, no México.

Com mais de 15 anos em empresas multinacionais, Armando js trabathou em empresas. dos setores automotivos, de eletrodomésticos e pintura. Altm disso, possui mais de oito anos de experiência em posiç̋es de liderança em diferentes áreas de Finanças, como Marketing s Vendas, Ptanejamento Financeiro, Controladoria, Tesouraria e Manufatura.

Armando ncarb baseado no Rio de Janeiro e se reportarb diretamente a Marco Silva, presidente da Nissan do Brasit, e fundionalmente a Alejandro Talonia, vice-presidente de ASF da Nissan LATAM. Armando substitui Frederico Carvatho, que recentemente assumiu um novo desafio como gerente geral de Finangas de Parcerias da Nissan Motor Company (NML).

Juntem-se a nós para darmos boas-vindas ao Armando em sua nova posiços. 
Anexo 2: Comunicação interna publicada em 28/01/2020.

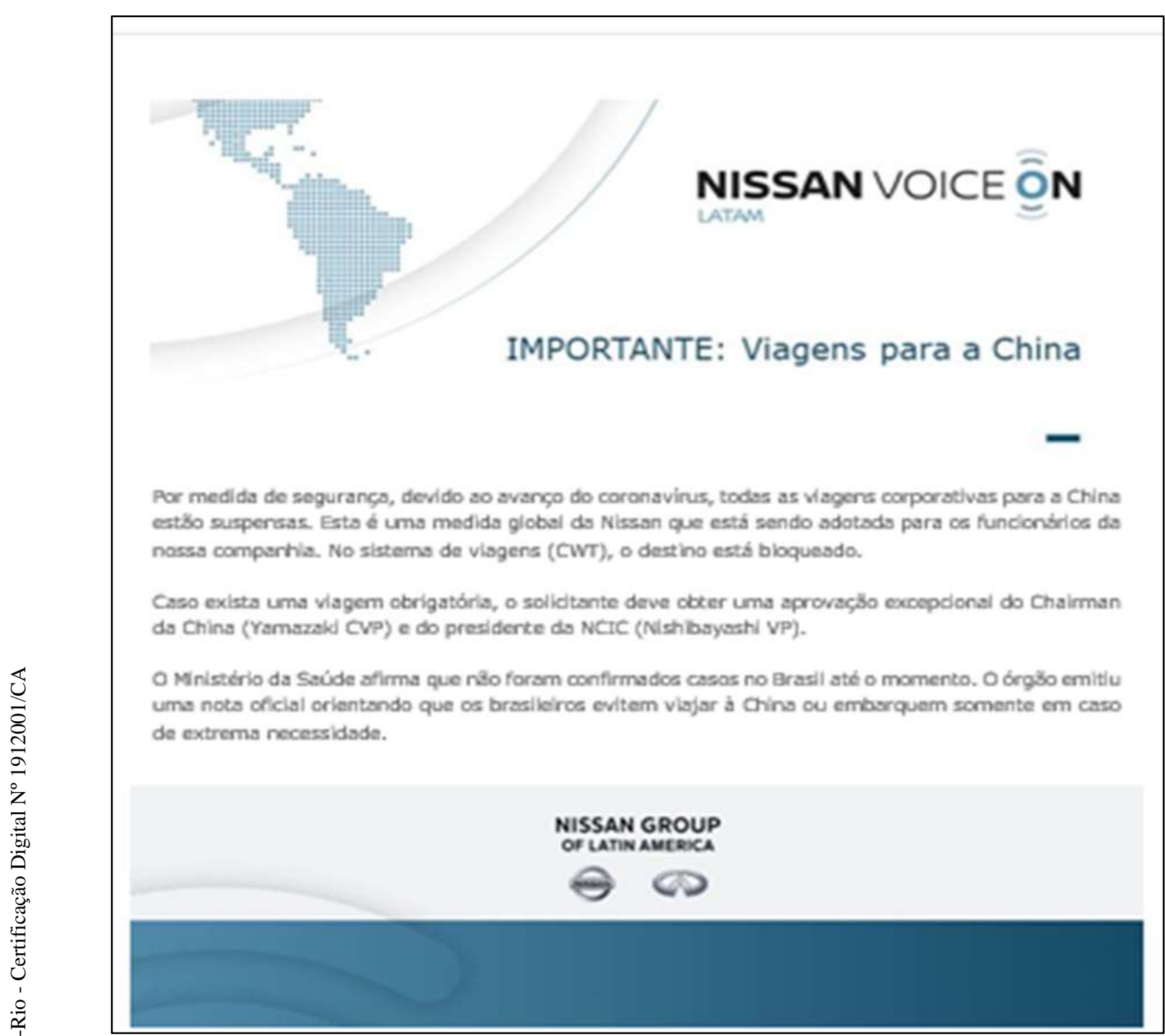


Anexo 3: Comunicação interna publicada em 10/02/2020.

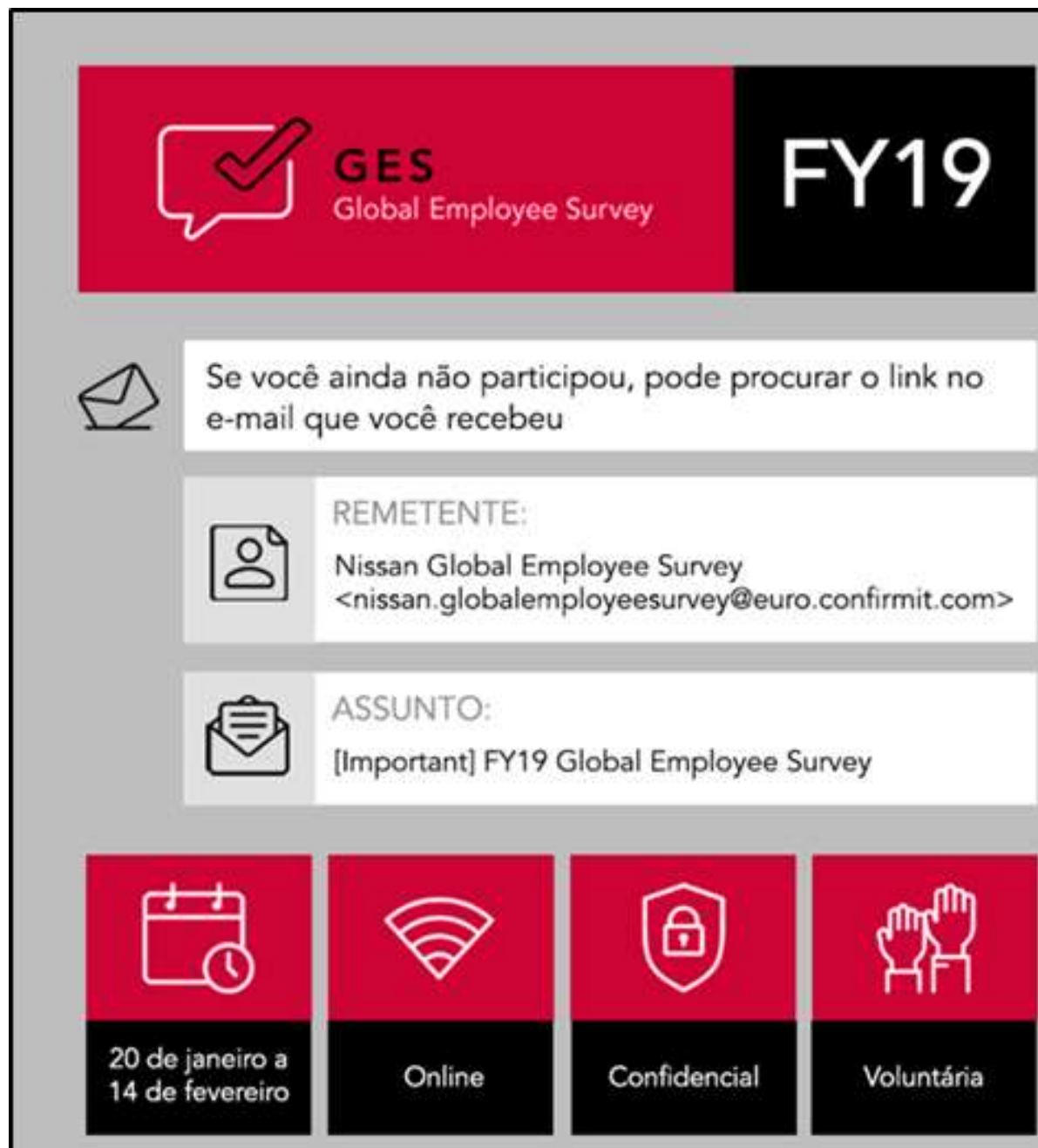

Se você não receber esse e-mail, entre em contato com o RH local. A pesquisa se aplica somente aos funcionários efetivos contratados até $1^{\circ}$ de novembro de 2019.

SUA OPINIÃO TRANSFORMA. COMPARTILHE.

\section{NISSAN}


Anexo 4: Comunicação interna publicada em 12/02/2020.

\section{NISSAN VOICE ON \\ BRASIL \\ Esclarecimento sobre o Coronavírus}

Munaialmente, a Nissan esta acompannanco de perto as noticias sobre o coronavirus para garantir a saúde e segurança de todos os colaboradores. No WIN, nossa intranet global, os funcionários podem ter acesso a mais informações sobre o tema.

Apesar de não existirem casos confirmados no Brasil de acordo com o Ministério da Saúde, confira abaixo algumas informaçōes sobre o novo virus e como se prevenir, de uma maneira geral, das doenças respiratórias.

\section{O que é o coronavírus?}

Coronavirus é uma familia de virus, conhecida pelos cientistas desde meados de 1960 capaz de gerar infeçôes respiratórias em seres humanos e em animais. Em geral, elas se manifestam de forma leve, com caracteristicas bastante semelhantes a um resfriado comum.

Orientaçốes para prevenção:

- Higienize constantemente as mãos com água e sabão

- Use lenço descartável para higiene nasal;

- Cubra o nariz e a boca ao espirrar e tossir;

- Evite tocar mucosas de olhos, nariz e boca;

- Não compartilhe objetos de uso pessoal como talheres, pratos, copos ou garrafas. Dưvidas frequentes:

1) Ter contato com encomendas recebidas de paises em que há casos

2) Como o coronavirus é transmitido?

A transmissăo dos coronavirus costuma ocorrer pelo ar ou por contato pessoal com secreç̧̄es contaminadas, como:

- Goticulas de saliva;

- Espirro:

- Tosse;

- Catarro;

- Contato pessoal próximo, como toque ou aperto de mão;

- Contato com objetos ou superficies contaminadas recentemente, seguido de contato com a boca, nariz ou olhos. Conforme mencionado anteriormente, objetos importados da China ou paises afetados não transitem o virus.

3) Em caso de dủvidas sobre a doença, o que eu devo fazer e qual área eu devo procurar?

o colaborador deve procurar atendimento médico ou a equipe de Saúde da Nissan, por meio dos contatos:

> Telefone: (24) 3386-6000

E-mail: ambulatorio@nissan.com.br

> Colaboradores lotados em Resende também podem procurar diretamente o ambulatório médico.

Importante: Reforçamos que, por medida de segurança, todas as viagens corporativas para a China seguem suspensas. Esta é uma medida global da Nissan que está send adotada para os funcionários da nossa companhia. No sistema de viagens (CWT), 。 destino está bloqueado.

Outras informaçốes sobre o coronavirus podem ser obtida no site do Ministério da Saúde. Clique aqui e saiba mais.

\section{NISSAN}


Anexo 5: Comunicação interna publicada em 05/03/2020.

\section{NISSAN \\ V마. ICES | Recursos humanos}

(2) Coronavírus

A Nissan está monitorando de perto as notícias sobre o Coronavírus para assegurar a saúde e segurança de seus colaboradores em todo o mundo. Na América Latina, foram confirmados recentemente alguns casos no México, no Brasil e na Argentina.

Nossos colaboradores devem seguir as orientações da OMS (Organização Mundial da Saúde), dos Centros de Vigilância Sanitária e outras autoridades de saúde pública.

\section{Prevenção}

- Lavar frequentemente as mãos com água e sabão ou higienizar com álcool em gel, de forma meticulosa.

- Manter uma distância mínima de 1 metro entre você e qualquer pessoa que esteja tossindo ou espirrando.

- Evite tocar os olhos, nariz ou boca.

- Certificar-se que você e as pessoas ao seu redor sigam a higiene respiratória: ao tossir ou espirrar, cobrir a boca e o nariz com o seu cotovelo dobrado ou utilizar um lenço de papel descartável, que deve s er jogado no lixo imediatamente após o uso.

- Ficar em casa se estiver se sentindo indisposto. Se estiver com febre, tossindo ou com dificuldade para respirar, procurar atendimento médico (telefonar antes). Seguir as orientações das autoridades de saúde pública.

\section{Restriçóes de viagem e trabalho}

Ao viajar, é de sua responsabilidade assegurar que você siga todas as orientações dadas continuamente pelas autoridades de saúde pública. Isso não traz benefícios apenas para a sua saúde, mas também para todos ao seu redor. É importante que os colaboradores pensem na totalidade do trajeto de ida e volta antes de planejar a viagem.

Reduza todas as viagens internacionais utilizando teleconferência e avaliando a necessidade de viajar nas próximas semanas. Em caso de absoluta necessidade, o funcionário deve obter uma aprovação por e-mail - em caráter excepcional - do presidente.

A Nissan LATAM trabalha arduamente para oferecer um ambiente de trabalho seguro para todos os colaboradores. Entretanto, a natureza do atual surto de Coronavírus apresenta desafios aos nossos esforços de manter uma resposta adequada a esta epidemia.

Se tiver dúvidas específicas ou estiver preocupado(a) sobre sua capacidade de realizar o seu trabalho devido às precauções locais, por favor, fale com seu gestor direto ou líder de $\mathrm{RH}$ local. 
Anexo 6: Comunicação interna publicada em 16/03/2020.

\section{NISSAN \\ VOICES Recuros hHumanos}

(?) Situação do Coronavírus na América Latina

A Nissan está acompanhando de perto a evolução do Covid-19 (Coronavírus) ao redor do mundo. A Nissan América Latina está monitorando todos os países da região e atualizando os times locais. Este é um momento de incerteza para todos, mas nós podemos contribuir seguindo as recomendações abaixo.

Todas as atualizações são efetivas a partir de hoje, 16 de março.

\section{Viagens Internacionais}

- Todas as viagens internacionais devem ser canceladas. o time de viagens da área de Recursos Humanos pode auxiliar com os cancelamentos.

\section{Específico para Funcionários Expatriados/Impatriados}

- Viagens de férias a seus países de origem (home-leave) devem ser adiadas até 31 de março

- Viagens de reconhecimento à nova localidade de trabalho (pre-assignment trips) devem ser adiadas e regras de visto para o país anfitrião devem ser observadas. Em caso de retorno de viagem, é mandatória quarentena de 14 dias.

\section{Viagens Nacionais}

- Evite viagens desnecessárias. Em casos inadiáveis, utilize luvas e máscaras durante o voo. É mandatória a aprovação da área de Recursos Humanos, do presidente e do Chairman da região.

\section{Eventos corporativos}

- Todos os eventos internos devem ser cancelados por hora.

\section{Visitantes e Reuniōes}

- Evite receber convidados durante esse período e não visite clientes e fornecedores. Dê preferência a reuniões via telefone, Skype, Jabber, videoconferência e Zoom. Caso necessário, todos os visitantes terão que responder a um formulário específico sobre riscos do Covid-19. 
Anexo 7: Comunicação interna publicada em 17/03/2020.

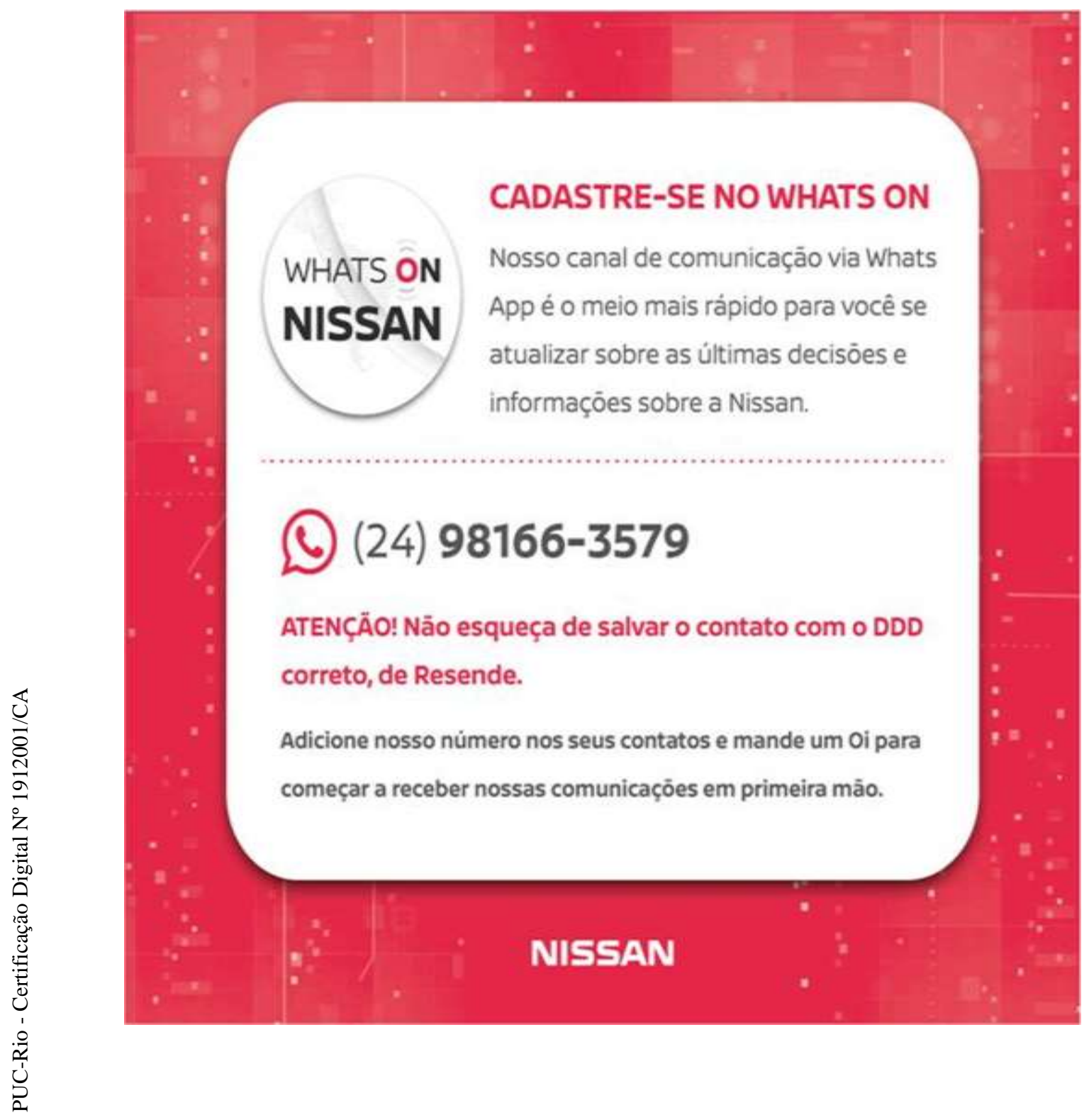


Anexo 8: Comunicação interna publicada em 17/03/2020.

\section{- CORONAVÍRUS}

\section{Prevenção é a melhor solução!}

O fim de semana está chegando, mas não podemos nos descuidar. Confira no vídeo abalxo como intensificar seus culdados de higiene e a sua atenção para evitarmos a proliferação desse vírus.

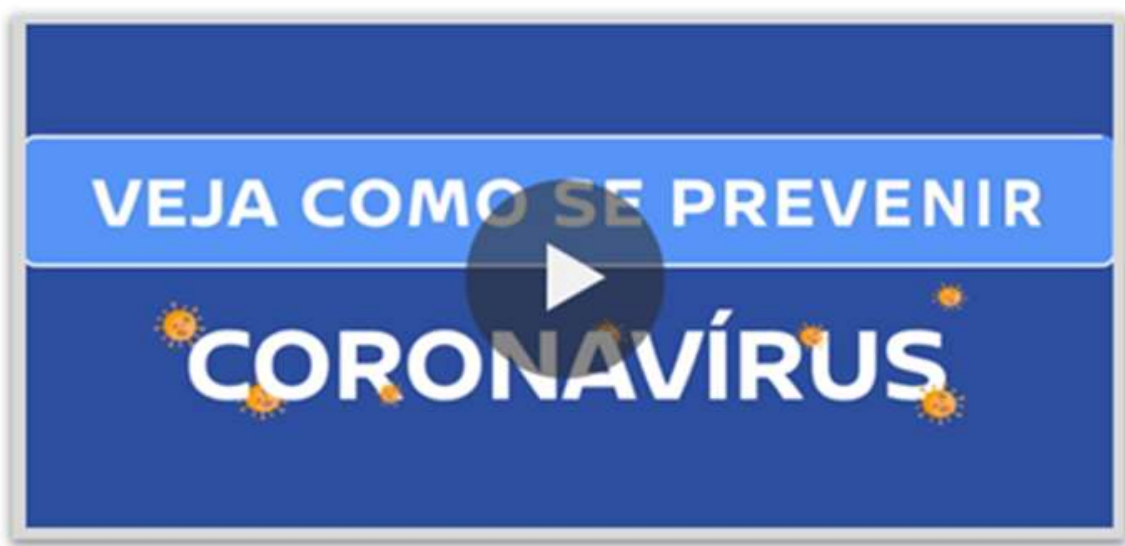

Compartilhe o video com seus familiares e amigos. Juntos somos mais fortes! 
Anexo 9: Comunicação interna publicada em 18/03/2020.

\section{NISSAN \\ V미도 | Recursos Humanos}

2. Atualização sobre a situação do

Prezados colaboradores,

A Nissan está acompanhando de perto as notícias sobre o Covid-19 (Coronavírus) ao redor do mundo para garantir a saúde e segurança dos nossos funcionários e seus familiares. Até o momento, nós não registramos nenhuma confirmação de casos de Coronavírus entre funcionários e colaboradores terceiros.

Independentemente disso, considerando as recomendaçōes dadas pelos governos locais e para contribuir com a contenção da proliferação da pandemia na nossa região, implementaremos o escritório virtual (virtual office) para todos os colaboradores e estagiários a partir de 19 de março. Esperamos que esta medida temporária se estenda até o fim do mês, mas forneceremos atualizações regulares sobre quando poderemos voltar para o escritório.

Pedimos que atentem para o fato que esta medida exclui algumas atividades dentro da Nissan na região, cuja presença física no escritório é essencial para a continuidade do negócio. Se você não tem certeza se isso se aplica a você, ou se você não tem condições de trabalhar de casa, por favor, converse sobre isso com o seu gestor ou o seu HRBP.

Durante este periodo de virtual office em todas as unidades da região, serão suspensos os serviços do restaurante e de transporte por ônibus fretado da empresa. Será mantido apenas o serviço médico, de limpeza e segurança.

Também pedimos que tenham em mente que o serviço VPN é necessário apenas para acessar os sistemas de informação da empresa. Não é necessário o uso de VPN para acessar o Skype, Zoom e e-mails. Nosso VPN é compartilhado com as equipes dos EUA e do México. Por isso, para assegurar uma melhor performance, pedimos que dê preferência para acessar os sistemas corporativos das 7 h da manhã ao meio-dia (GMT-3 horas).

Conforme comunicado anteriormente, todas as viagens internacionais devem ser canceladas e as viagens não essenciais dentro do país devem ser evitadas, assim como os eventos corporativos e reuniōes presenciais. Devemos assegurar que estamos seguindo estas medidas simples para reduzir nossa exposição ao vírus.

Estamos atuando para não haver interrup̧̧ões neste momento de mudança temporária na forma como trabalhamos, para proteger a saúde e segurança de todos os colaboradores, ao mesmo tempo em que continuamos oferecendo um atendimento completo e robusto aos clientes. Agradecemos profundamente o seu apoio e profissionalismo.

Em caso de dúvidas, entre em contato com seu gestor direto ou HRBP. 
Anexo 10: Comunicação interna publicada em 26/03/2020.

\section{ATIVIDADES NAS UNIDADES DA NISSAN DO BRASIL}

\section{Prezados colaboradores}

Nos últimos dias, diferentes açóes, que impactaram as equipes/unidades da empresa, foram tomadas pela Nissan do Brasil para assegurar a saúde dos colaboradores e seus familiares. além de garantir a continuidade do negócio neste periodo Para todos entenderem como cada unidade da empresa está neste momento, segue abaixo um resuma

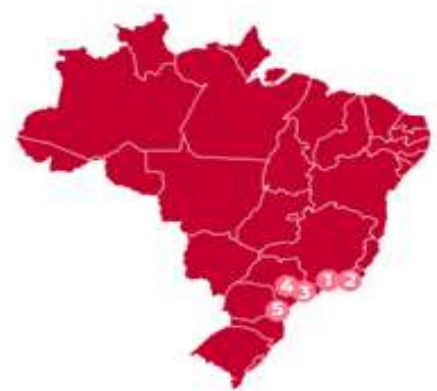

o Fábrica de Resende e Armazèm de Peças

- interrup̧̧̧o da produçấo de 25 de março a 21 de abril. Retorno no dia 22 de abril

- Ferias coletivas e banco de horas para a maior parte do efetivo

- Administrativo - as equipes que nJ̄o entraram em férias eståo em virtual office

- Equipes reduzidas para garantir a operaçáa, manutençáo e segurança na fábrica e no armazèm.

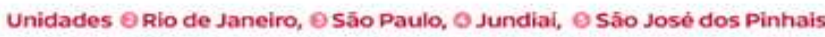

- Em virtual office mas parte das equipes vão entrar em férias coletivas a partir de 19 de abril

Importante destacar que, em conformidade com a legislaçâo trabalhista brasileira, de 10 a 17 de abril, o direcionamento é que todos os funcionários da Nissan devem estar em férias coletivas. A excȩ̣âo sào equipes de atividades essenciais de continuidade do negöcio, que, neste caso, continuarâo em virtual office. Estas pessoas/equipes estâo sendo definidas com os gestores.

Como esta açāo envolve equipes das mais diferentes ăreas, mais informaçōes para cada time seráo dadas pelo $\mathrm{RH}$ local e pelos gestores.

Ressaltamos que, diariamente, mesmo de maneira virtual, executivos da empresa estâo se reunindo para acompanhar e tratar das atividades da Nissan do Brasil para garantir o funcionamento neste momento e assegurar a preparaçâo da empresa para a retomada que está por vir.

Reforçamos que muitas das medidas tomadas sâo excepcionais e seguem o esforço đa sociedade e dos governos para tentar controlar a proliferaçáo da pandemia.

\section{Ponto Eletrônico}

Como todos sabem, a Nissan, por liberalidade, já adota virtual office com parte de suas equipes em alguns dias da semana.

Em funçào do esforço para conter a pandemia de covin-19 (coronavirus), nas úttimas semanas a empresa passou a adotar, excepcionalmente, a pratica de virtual office (trabaiho de casa) para os funcionarios dos escritorios do Brasil. Neste caso, seguindo a legislaçâo trabalhista vigente, os funcionários estáo isentos de marcar o ponto eletrônico, nào haven đo também o registro de horas extras e intervalos para refeiçă

Reforçamos a importáncia de controlarem e equilibrarem bem suas atividades, se organizem, ainda mais neste momento de isolamento social. 
Anexo 11: Comunicação interna publicada em 27/03/2020.
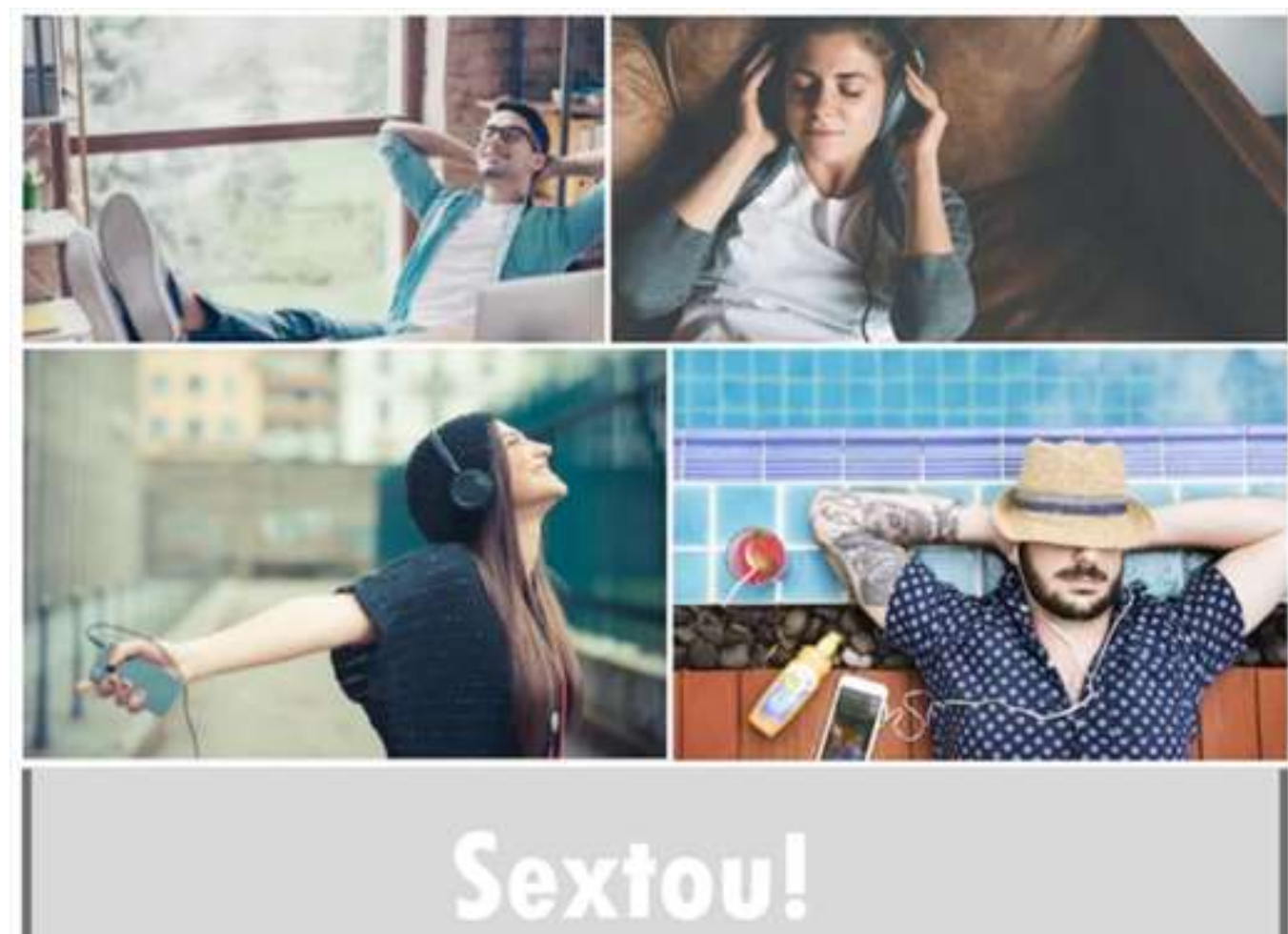

É hora de relaxar e escutar as playlists que a Nissan preparou para você.

Clique aqui e auça! 
Anexo 12: Comunicação interna publicada em 02/04/2020.

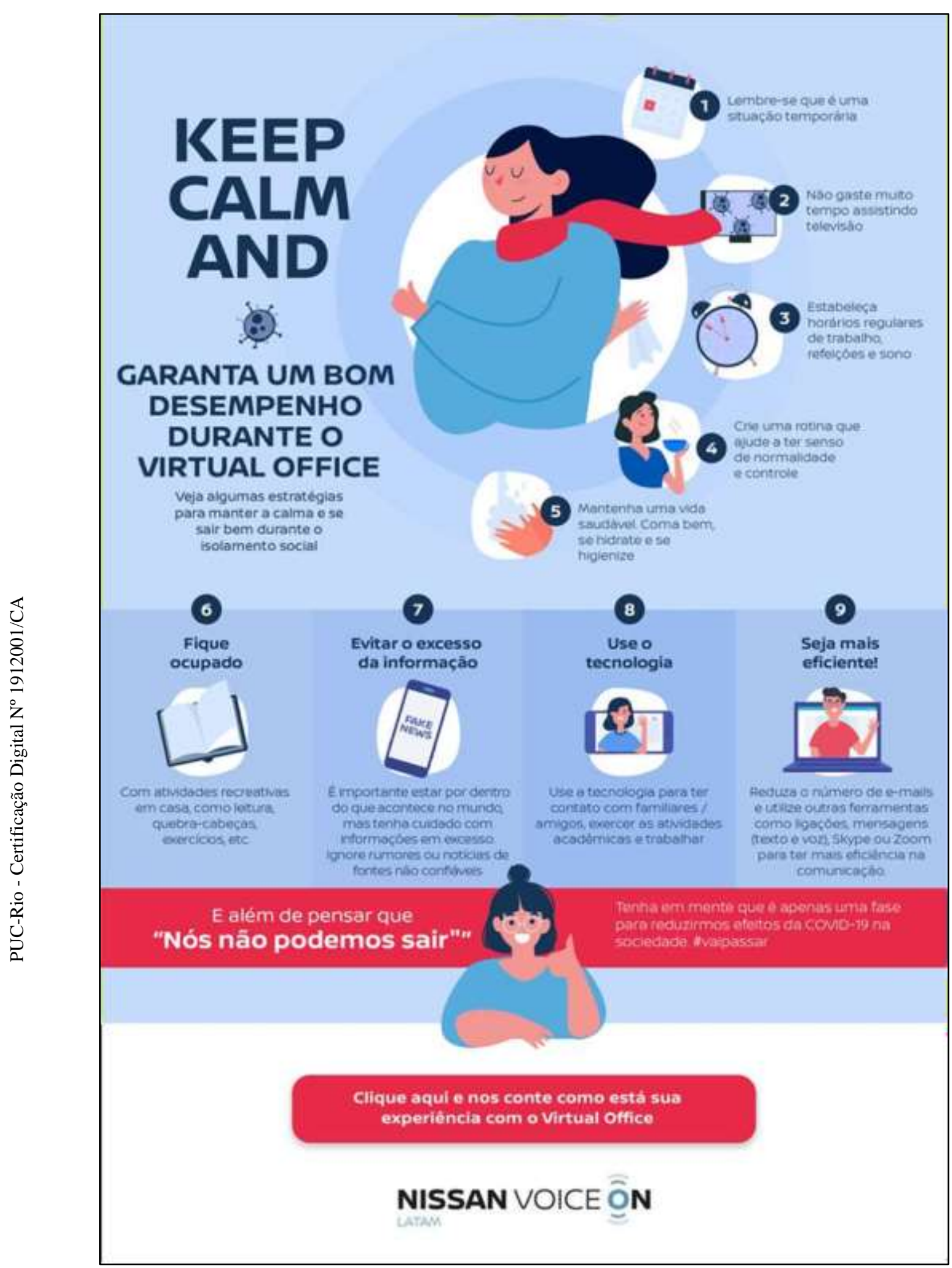


Anexo 13: Comunicação interna publicada em 02/04/2020.

\section{Saiba como entreter as crianças durante o isolamento social}

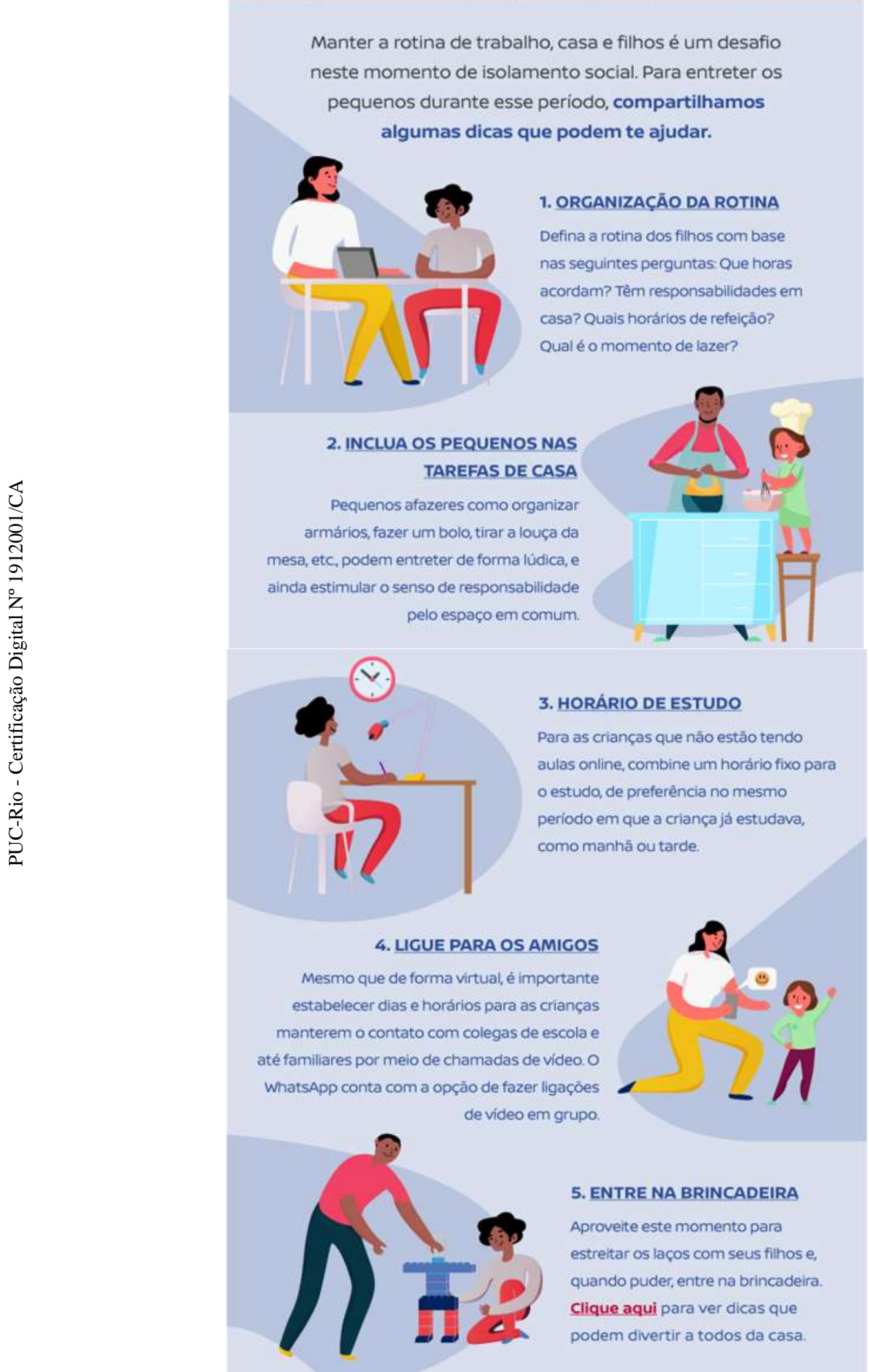


Anexo 14: Comunicação interna publicada em 09/04/2020.

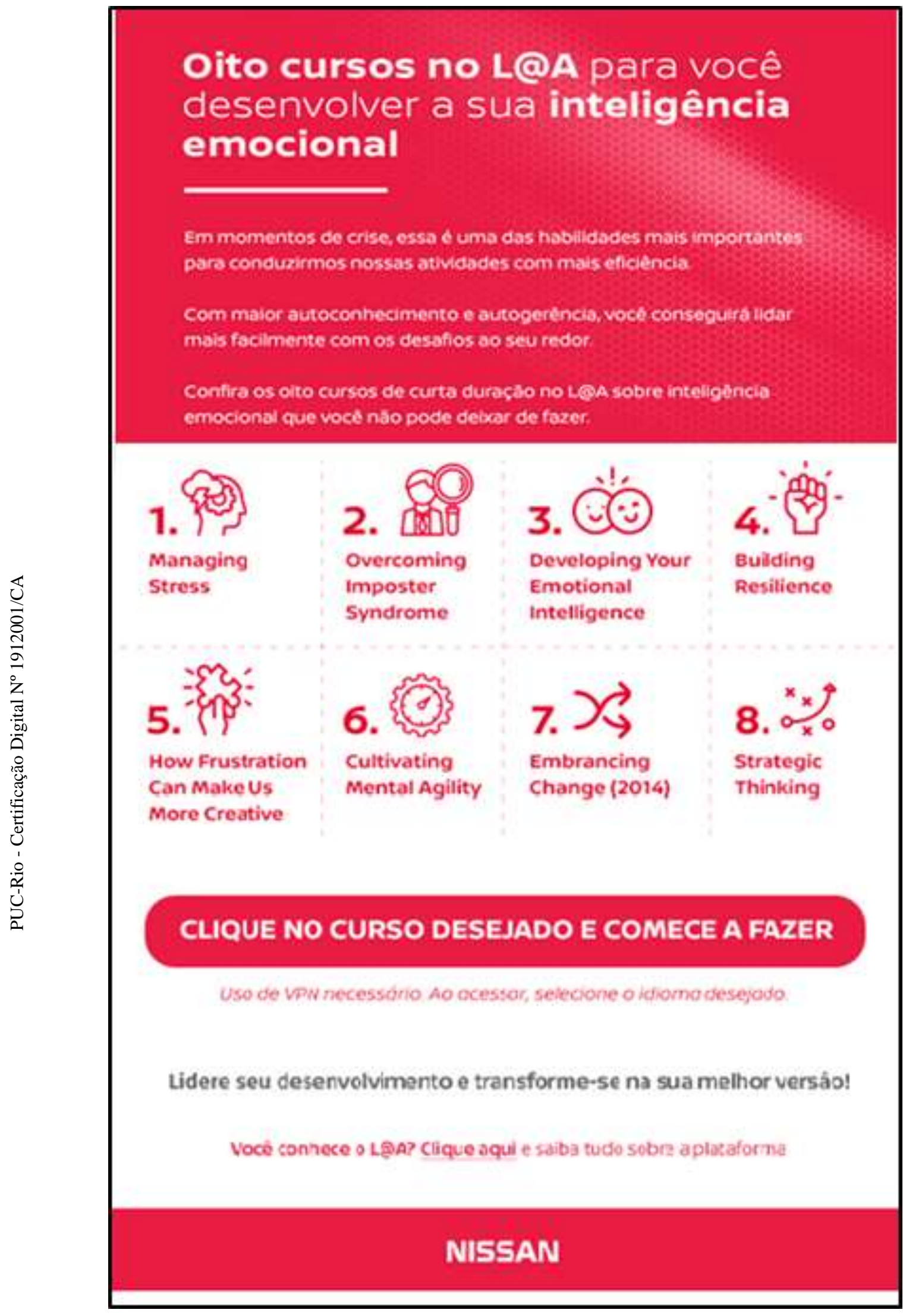


Anexo 15: Comunicação interna publicada em 22/04/2020.

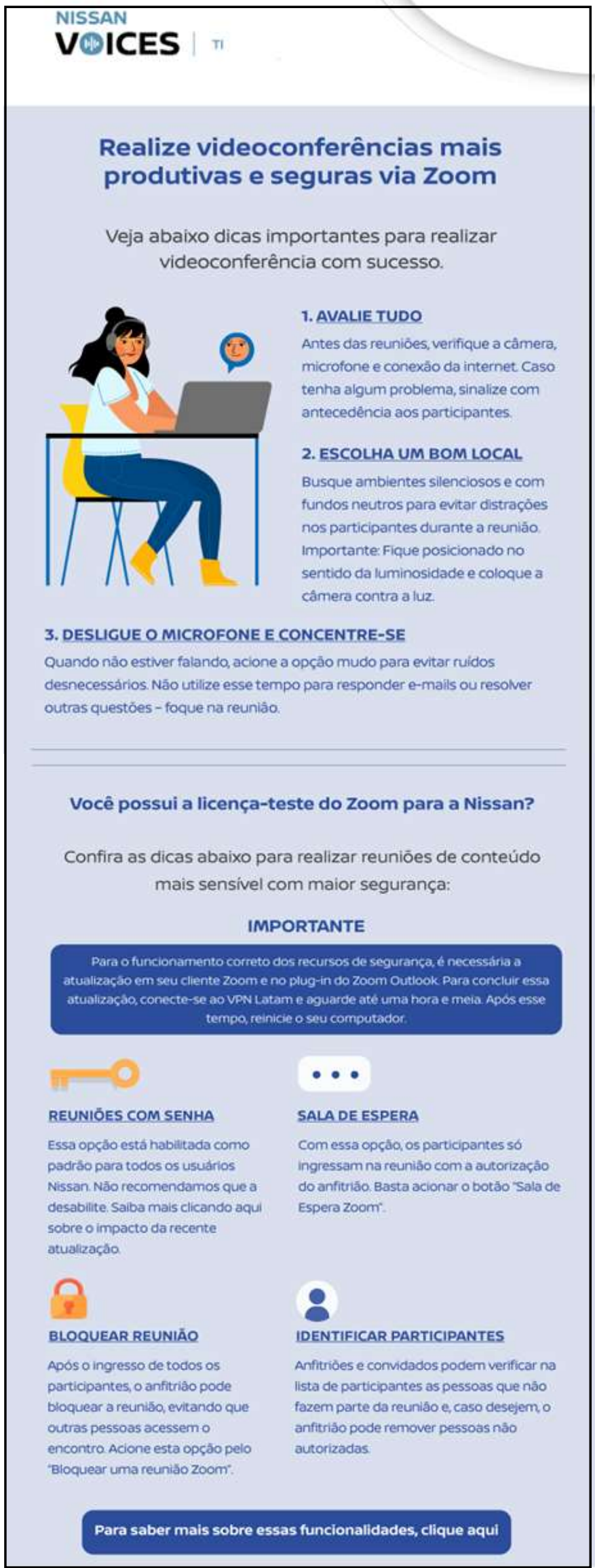


Cont. Anexo 15: Comunicação interna publicada em 22/04/2020.

\section{Você está seguindo as melhores práticas durante o Virtual Office?}

Trabalhar fora do escritório exige uma disciplina maior devido as distrações que temos ao longo do dia.

Veja anexo o Guia das Melhores Práticas durante o Virtual Office, um documento que traz hábitos para você otimizar o seu dia e aumentar a sua produtividade.

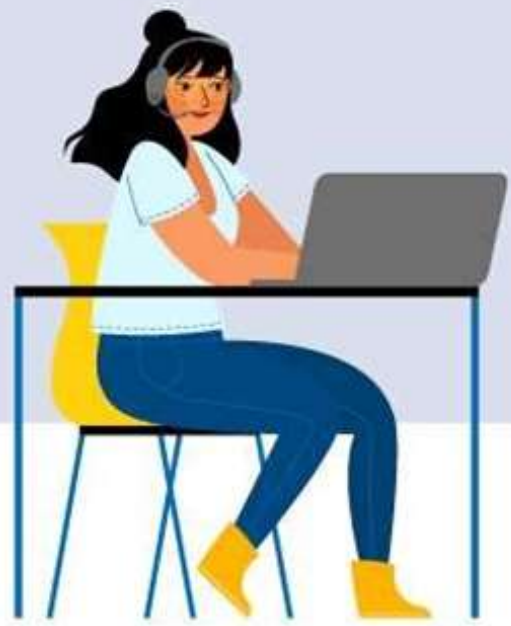


Anexo 16: Comunicação interna publicada em 22/04/2020.

\section{Cuide de sua saúde financeira}

Neste momento é importante darmos uma atençăo especial à nossa saúde financeira, por isso, preparamos algumas dicas para você cuidar do seu dinheiro.

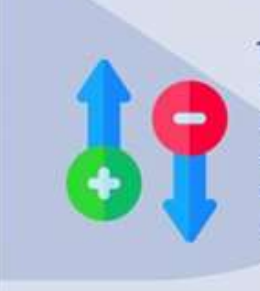

\section{LISTE SEUS GANHOS E GASTOS}

Em uma planilha, liste os ganhos, as despesas fixas e também os gastos variáveis (de estilos de vida e superftuos). No final voce podera ver quanto suas despesos consomem o seu rendimento e reavalar os seusgastos

\section{LISTE TODAS SUAS DIVIDAS}

Na mesma planilha, crie uma coluna para descrever quais dividas estão consumindo parte do seu orçamento (empréstimos, faturas do cartáa, etc).

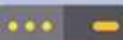

3. ANALISE O SALDO AO FINAL DE CADAMES Sea diferença entre ganhos e gastos é maior do que vocé pensava, aproveite o susto para repensar as atitudes ou cortar os excessos:

4. RENEGOCIE AS DIVIDAS MAIS URGENTES E ORGANIZE AS OUTRAS

Prepare propostas de pagamento que caibam em seu orçamenta com buncos, cheque especial rotativo do cartảo de crédito e crédito para negativados podern ser trocados por dúvidas mais baratas, como crédito pessoal ou empréstimo consignado.

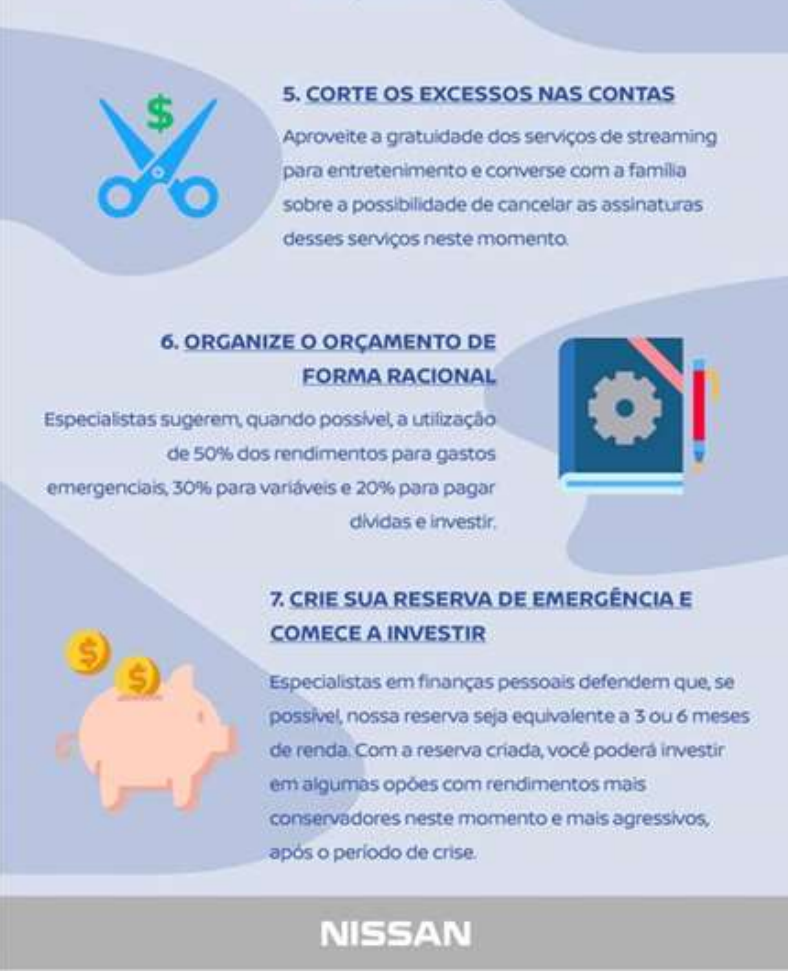


Anexo 17: Comunicação interna publicada em 30/04/2020.

\section{VOCÊ SABE O QUE SEUS COLEGAS DA NISSAN ANDAM FAZENDO?}

Eles estão somando forças para ajudar quem mais precisa neste momento!

Nas últimas semanas, mutos colaboradores se mobilzaram para ajudar a criar e contribuir com acoes de solidariedade da Nissan do Brasi durante a pandemia do Coronavirus.

Confira ababxo um video com as iniciativas desenvolvidas ate agora:

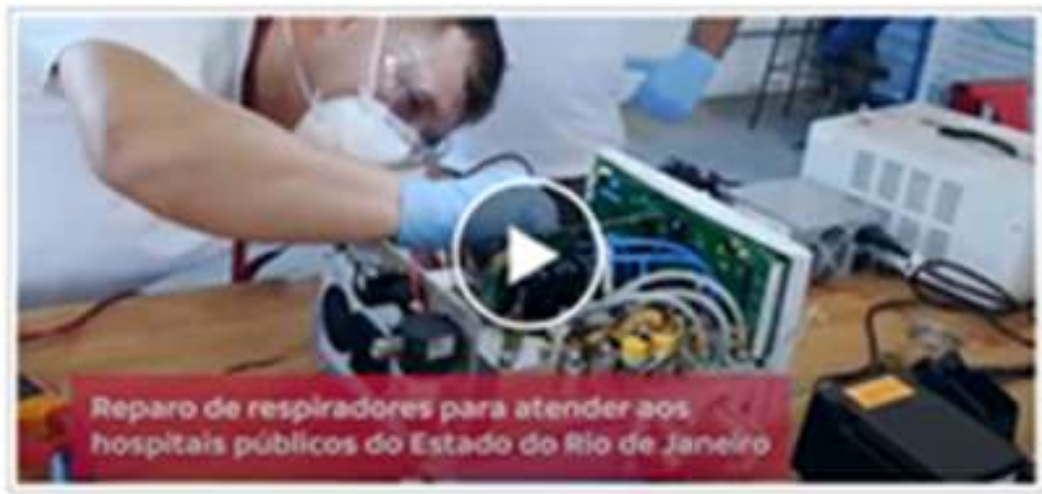

\section{\#EstamosComVocê}


Anexo 18: Comunicação interna publicada em 30/04/2020.

\section{NOS 6 ANOS DA NOSSA FÁBRICA DE RESENDE,

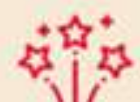 MONTE O NISSAN KICKS NA SUA CASA}

No mês de abril a fábrica da Nissan em Resende completou seis anos.

Na trilha de nossa história passamos por momentos importantes, como:

\section{-}

Produçóo de 400 mil carros emotores

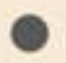

Fabricaçooo de 100 mil unidades do Nissan Kicks

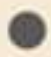

As duas ediçces do Nissan Kicks UEFA Champions Leogue

Só chegamos até aqui porque temos um time comprometido com o resultado e que se dedica a fazer sempre o melhor a cada dia!

E se nào podemos estar juntos para produzir os carros, convidamos você para celebrar e montar um Nissan Kicks em casa. Veja as instruçóes em anexo e, depois de montado, mande uma foto para a gente.

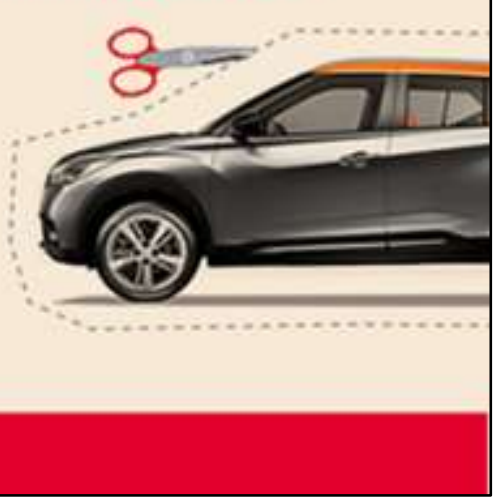

\section{NISSAN}


Anexo 19: Comunicação interna publicada em 07/05/2020.

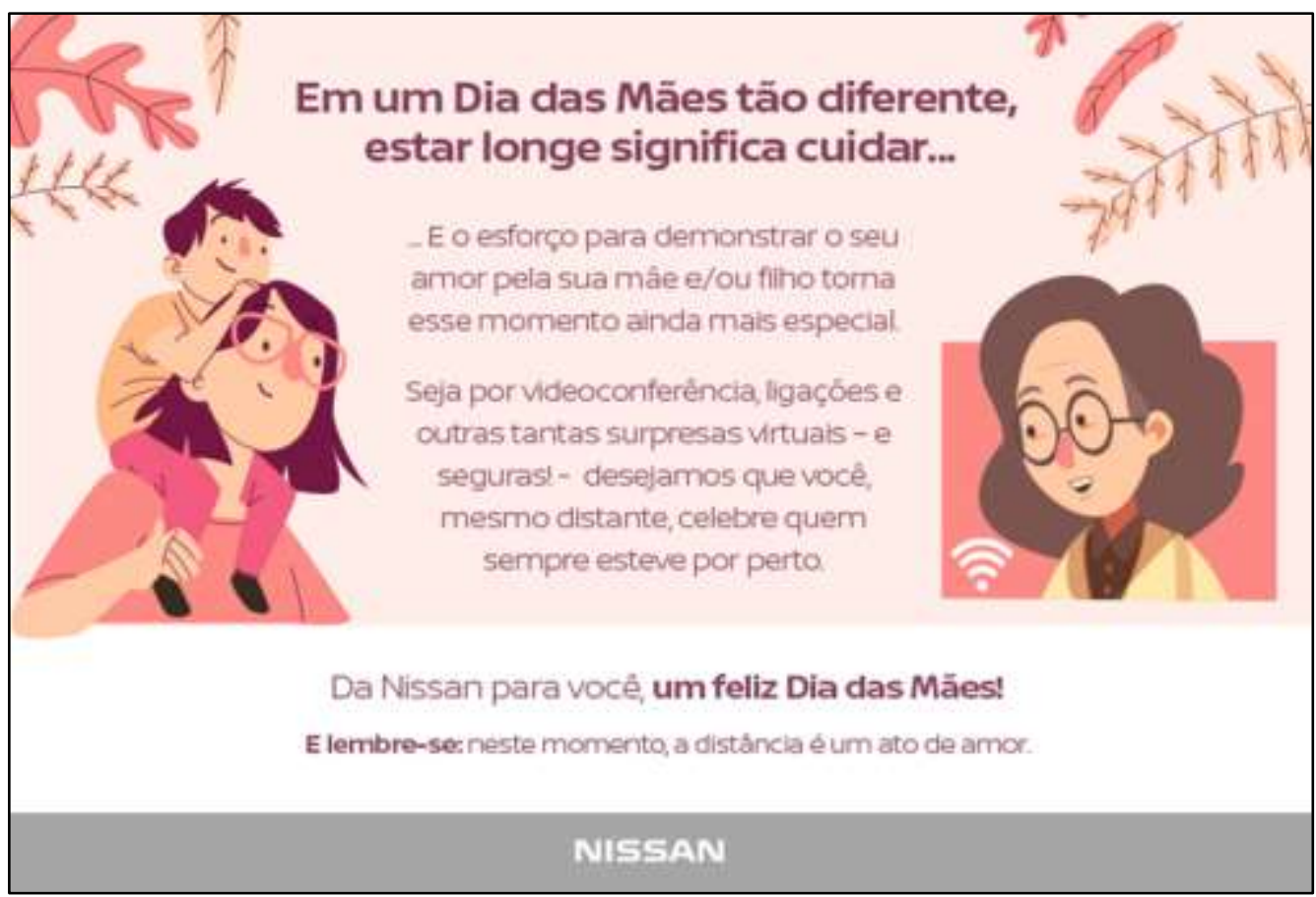

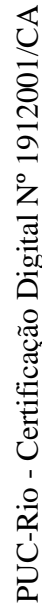


Anexo 20: Comunicação interna publicada em 03/06/2020.

\section{REGRAS DE HIGIENE NA NISSAN}

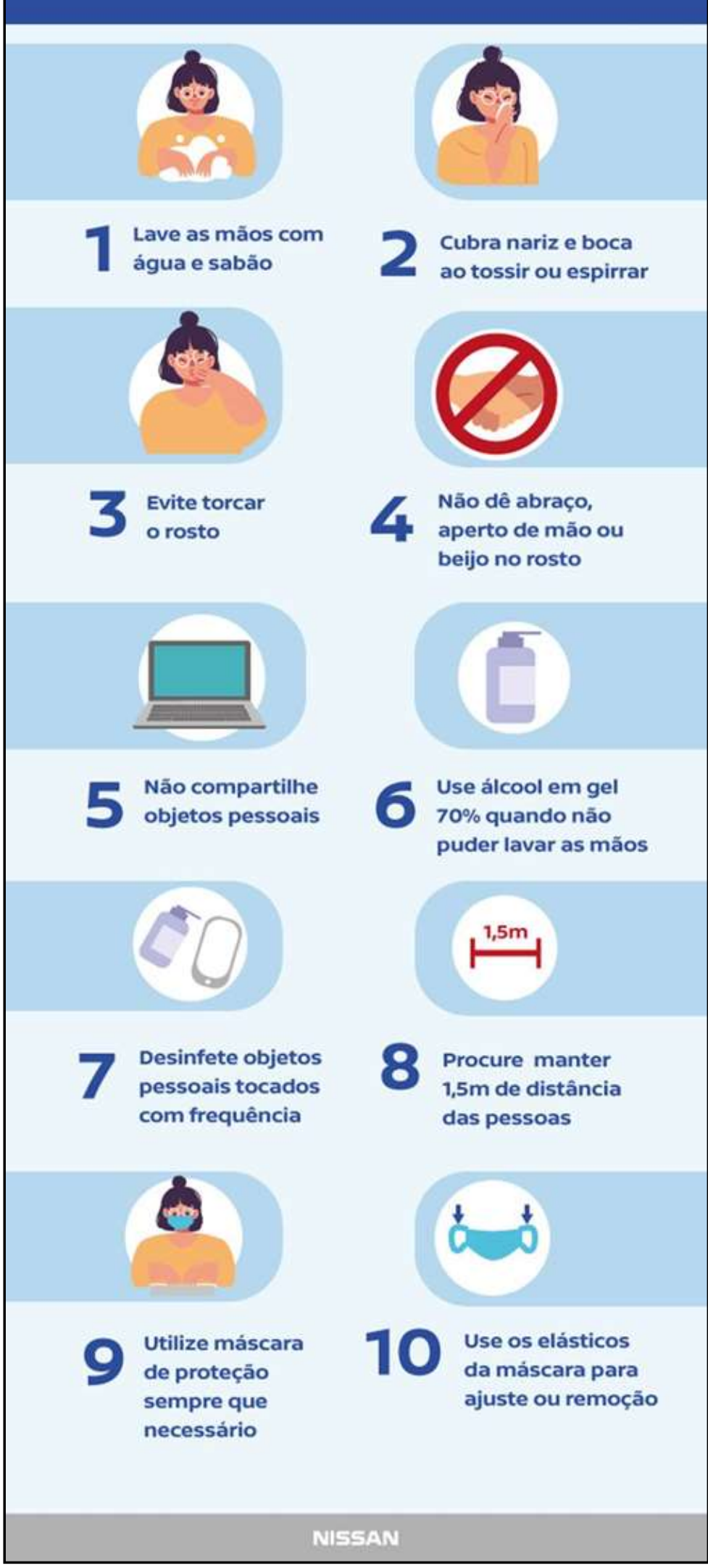


Anexo 21: Comunicação interna publicada em 15/06/2020.

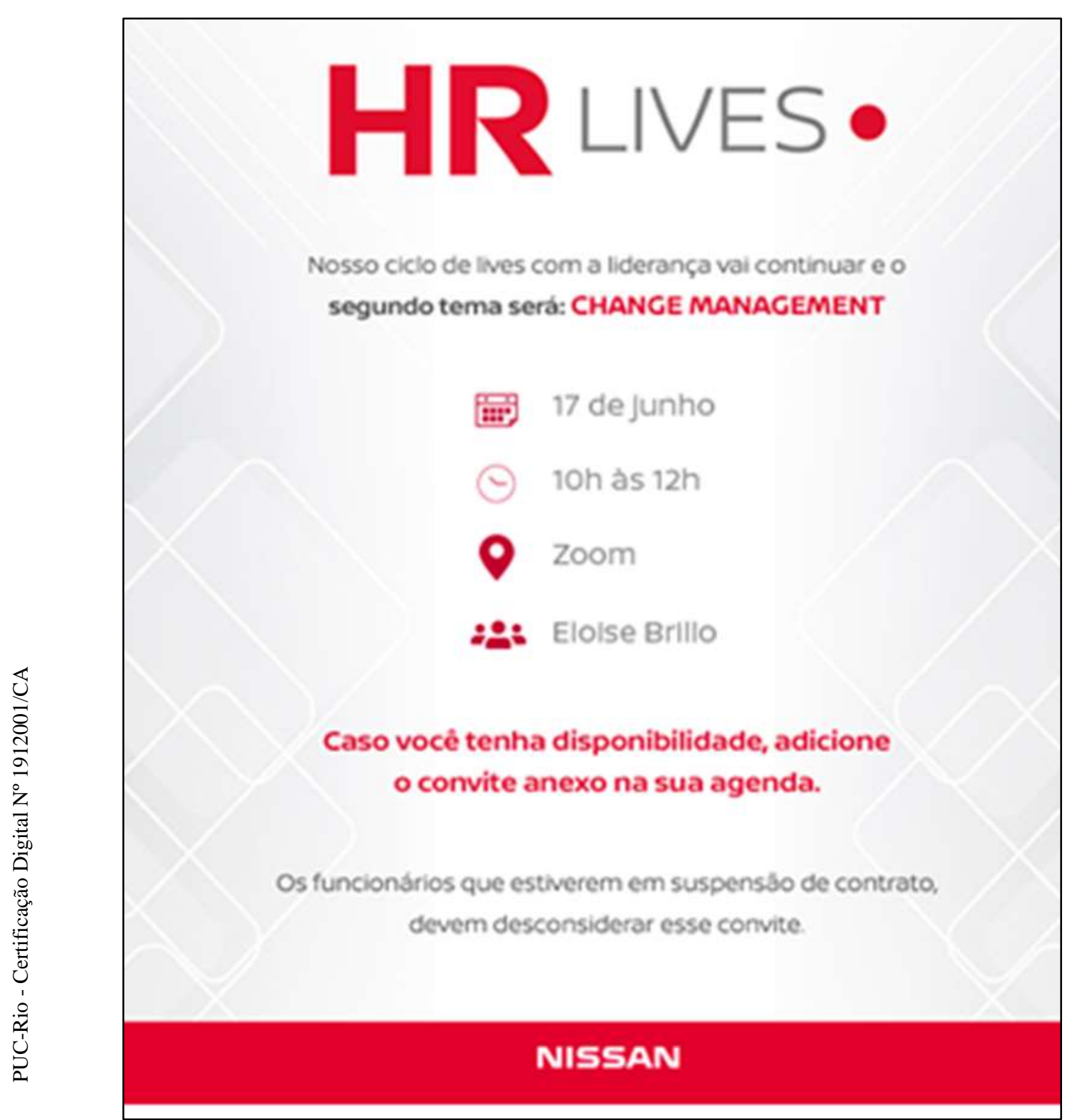


Anexo 22: Comunicação interna publicada em 15/06/2020.

\section{Protocolos de Segurança da Nissan do Brasil}

\section{Uso de máscara}

Em breve estaremos juntos de novo em nossos escritórios e fabrica. Mas antes de tudo, queremos que vock conheca todos os protocolos de segurança para reduzirmos ao mbimo os riscos de contaminacbo.

Hoje, vamos falar sobre o uso correto das máscaras de proteçlo e EPis. É só cllcar e conferirt 
Cont. Anexo 22: Comunicação interna publicada em 15/06/2020.

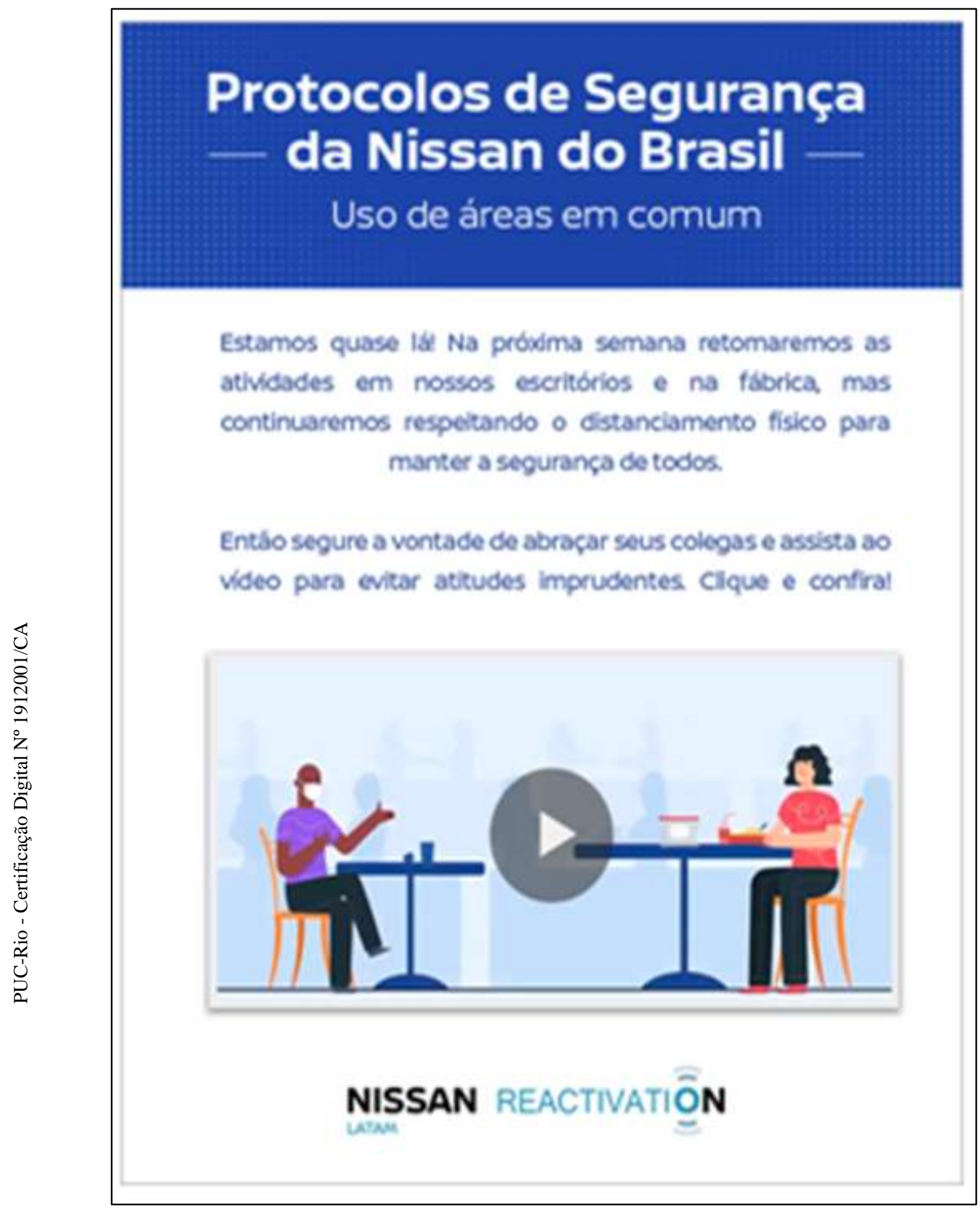


Anexo 23: Comunicação interna publicada em 17/06/2020.

\section{Protocolos de Segurança da Nissan do Brasil}

\section{Cuidados no transporte}

Nhda temos abuns culdados multo importantes para informar a voct antes do votarmos as atudades prezenclats nos escrikólos e fabrica voct ys percebeu que o nosso dever com a seguranga comesa muto antes de assumimos nosses postos de trabsha certo?

Agora, queremos compartilhar quals acbes voce precha adotar ao usar transporte, seja cle fretado. peiblice ou privado, e as ctapas de seguranca que nosso time val reallzar na sua chegada a unldade. Cligue e assistal

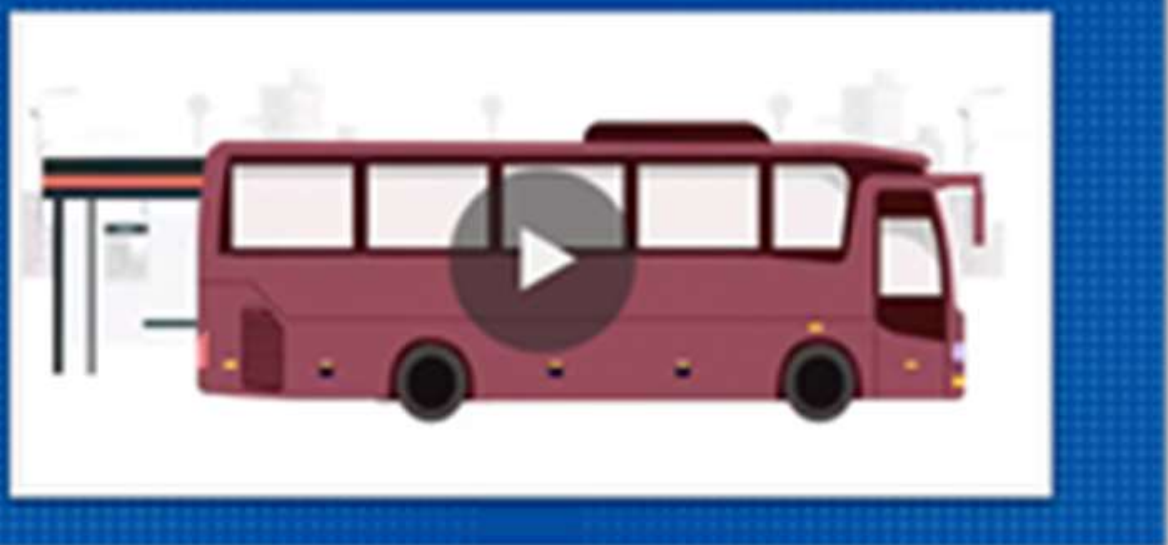

Nos vemos na próxima semana!

NISSAN REACTIVATIŌN 
Cont. Anexo 23: Comunicação interna publicada em 17/06/2020.

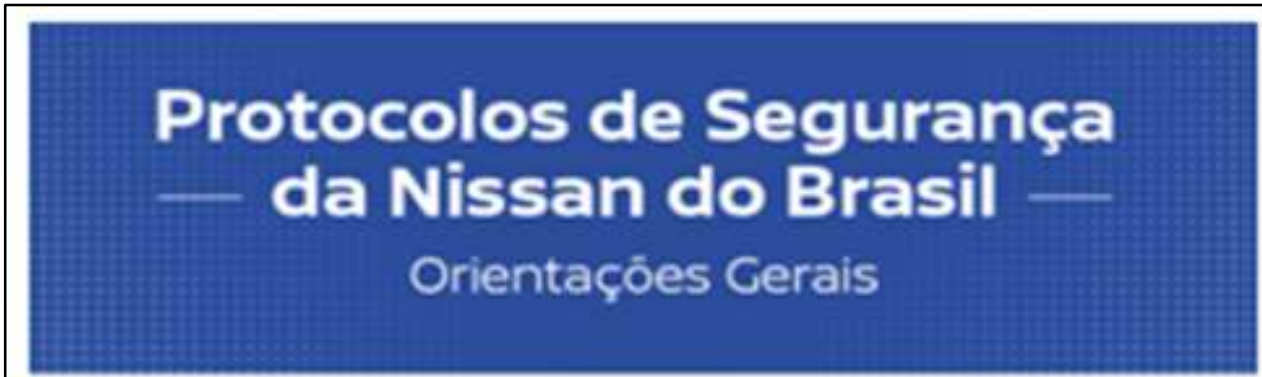

Está com febre (temperatura acima de $\left.37,5^{\prime}\right)$ ? ( ) $\operatorname{sim} \propto$ NSo

Tem coriza, dor de gatgants, tosse ou dificuldade de respira

( ) $\operatorname{sim}(\infty)$ Nåo

Na proxima semana, começaremos a retomar as atividades presenciais em nossos escritórios e fabrica. para a segurança de todos, a NBA adotou uma série de protocolos que você conhecerá ao longo desta semana. E fundamental que vocî veja os conteudos com atençio.

Conheça, hoje, o protocolo de autoavaliaçâo, de distanciamento físico e de cuidados com a higiene.

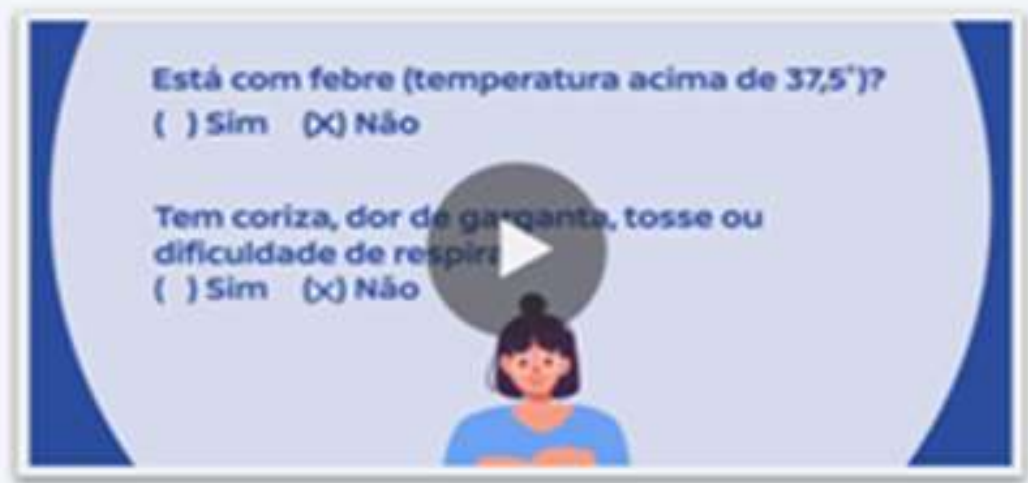


Anexo 24: Comunicação interna publicada em 03/07/2020.

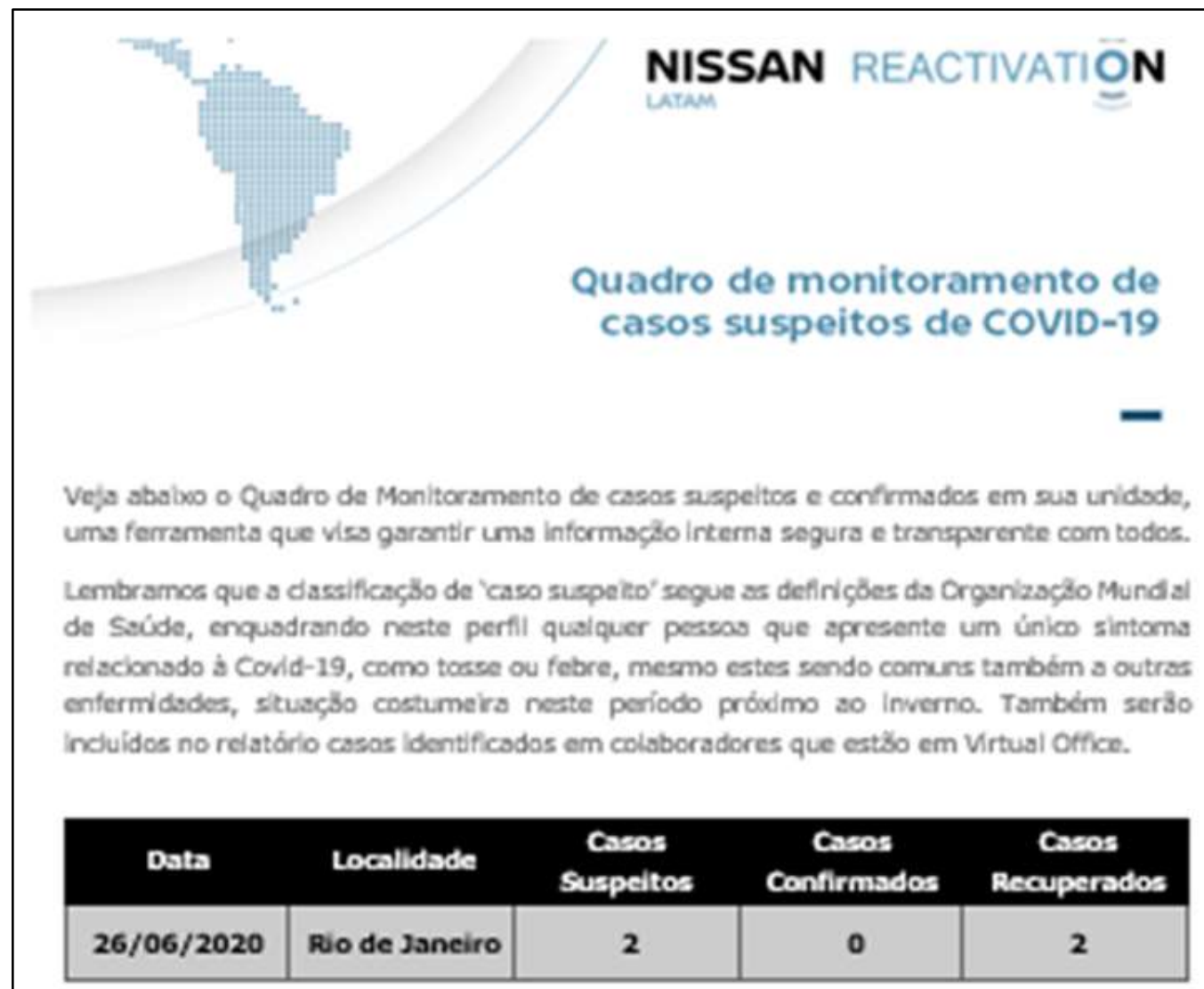

Ao ser identificado um caso suspeito cm um funciondílo que compareceu so trabalho, a empress seguirs todo o protocolo de higienkaço e controle jo definido previamente, conforme regres das agêncles sanitírias e crtidades de saúde.

Para a Nissan, a segurança e a saíde de seus colaboradores é prioridade. Por lsso, no retorno das atividades presendais da empresa no Brasil estamos seguindo protocolos rigidos de seguranca que sio avaladoe constantemente.

\section{NISSAN GROUP OF LTIN RUETECA

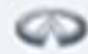


Anexo 25: Comunicação interna publicada em 03/07/2020.

\section{PROTOCOLO DE ÁREAS EM COMUM}

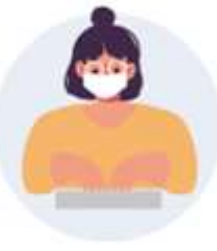

Use a máscara de proteção

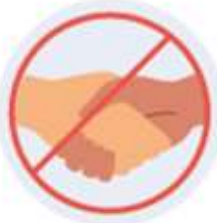

Evite aperto de mãos e abraços

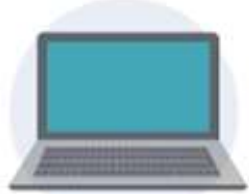

Desinfete objetos e superficies tocadas com frequência com pano liso e umedecido com álcool líquido $70 \%$

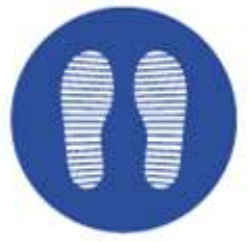

Respeite a orientação de afastamento de $1,5 \mathrm{~m}$ e sinalizações no piso

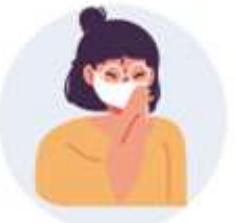

Mesmo utilizando máscara, cubra a boca e o nariz com o seu cotovelo dobrado ao tossir ou espirrar

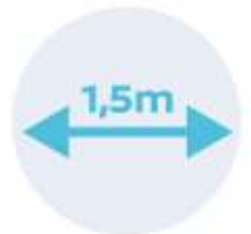

Obedeça ao rodizio e mantenha o

distanciamento de 1,5 metro dos colegas de trabalho

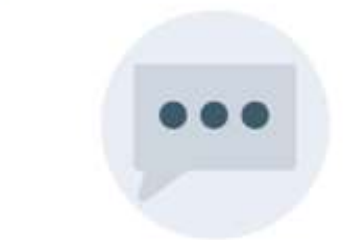

Em caso de sintoma de gripe ou resfriado, reporte imediatamente seu gestor
Faça uso do álcool em gel $70 \%$ sempre que possivel

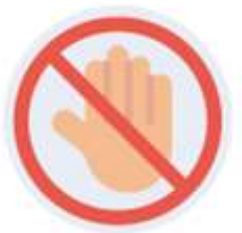

Não toque em olhos, nariz e boca sem que as mãos estejam limpas

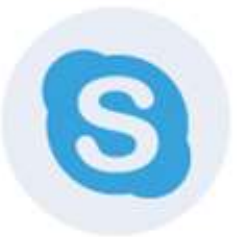

Evite reuniōes presenciais. Opte por utilizar o Zoom ou Skype 